2. -

iii)

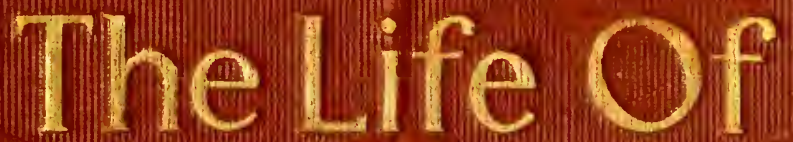

J.H.Fabre

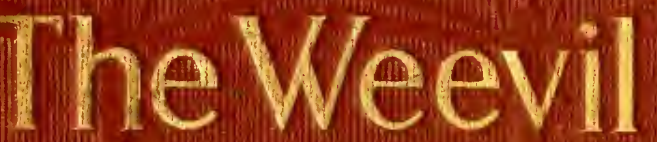




THE LIFE OF THE WEEVIL 


\section{BOOKS BY J. HENRI FABRE}

THE LIFE OF THE SPIDER THE LIFE OF THE FLY THE MASON-BEES BRAMBLE-BEES AND OTHERS THE HUNTING WASPS THE LIFE OF THE CATERPILLAR THE LIFE OF THE GRASSHOPPER THE SACRED BEETLE AND OTHERS THE MASON-WASPS

THE GLOW-IVORM AND OTHER BEETLES : MORE HUNTING WASPS THE LIFE OF THE WEEVIL 


\title{
THE LIFE OF THE WEEVIL
}

\author{
BY \\ J. HENRI FABRE
}

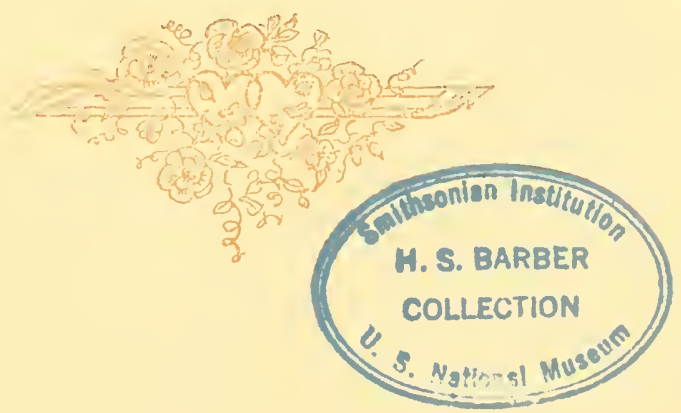

TRANSLATED BY

Alexander Teixeira de Mattos

PELLOW OF THE ZOOLOGICAL SOCIETY OF LONDON

\author{
NEW YORK \\ DODD, MEAD AND COMPANY \\ 1922
}


COPTRIGHT, 1922

BY DODD, MEAD AND CONPANY: INO. 


\section{TRANSLATOR'S NOTE}

I have gathered into this volume the essays on Weevils contained in the Souvenirs entomologiques, lest I should swell unduly the number of volumes devoted to Beetles, of which there will be three in all, or four if we include the present book.

Chapters I. and VII. to IX. have already appeared, wholly or in part, in an illustrated miscellany, entitled The Life and Love of the Insect, translated by myself and published by Messrs. Adam and Charles Black (in America by the Macmillan Co.), and Chapter V. and parts of Chapters XI. and XII. in a similar volume, entitled Social Life in the Insect World, translated by Mr. Bernard Miall and published by Messrs. T. Fisher Unwin Ltd. (in America by the Century Co.). I am permitted by arrangement with the firms named to retranslate and reissue the chapters in question for the purpose of this collected and definitive edition of Fabre's entomological works.

I am also under no small obligation to $\mathrm{Mr}$. Miall, who has given me the benefit of his assistance throughout.

Alexander Teixeira de Mattos.

VentNoR, 30 November, I920. 



\section{CONTENTS}

PAGE

TRANSLATOR'S NOTE • • • • • • V Chapter

I THE OLD WEEVILS • • • • I I

II THE SPOTTED LARINUS . . . 23

III THE BEAR LARINUS • • • • 53

IV THE BOTANICAL INSTINCT • . 72

V THE ELEPHANT WEEVIL . . 88

VI THE NUT-WEEVIL • • • • II 7

VII THE POPLAR-WEEVIL • • . 139

VIII THE VINE-WEEVIL . . . . I 58

IX OTHER LEAF-ROLLERS • • • I75

' $\mathrm{x}$ THE SLOE-WEEVIL • • • 196

XI THE PEA-WEEVIL: THE EGGS . 229

XII THE PEA-WEEVIL: THE LARVA . 248

XIII THE HARICOT-WEEVIL . . . 265

XIV THE IRIS-WEEVIL • • • . 292

XV THE CIONUS . . . . . 306

INDEX . . . . . . 343 

THE LIFE OF THE WEEVIL 


\section{CHAPTER I}

THE OLD WEEVILS

IN winter, when the insect takes an en1 forced rest, the study of numismatics affords me some delightful moments. I love to interrogate its metal disks, the records of the petty things which men call history. In this soil of Provence, where the Greek planted the olive-tree and the Roman planted the law, the peasant finds coins, scattered more or less everywhere, when he turns the sod. He brings them to me and consults me upon their pecuniary value, never upon their meaning.

What matters to him the inscription on his treasure-trove! Men suffered of yore, they suffer to-day, they will suffer in the future: to him all history is summed up in that! The rest is sheer futility, a pastime of the idle.

I do not possess this lofty philosophy of indifference to things of the past. I scratch 


\section{The Life of the Weevil}

the piece of money with my finger-nail, I carefully strip it of its earthy rind, I examine it with the magnifying-glass, I try to decipher its lettering. And my satisfaction is no small one when the bronze or silver disk has spoken. For then I have read a page of humanity, not in books, which are chroniclers open to suspicion, but in records which are, in a manner, living and which were contemporary with the persons and the facts.

This bit of silver, flattened with the die, speaks to me of the Vocontii. ${ }^{1}$

"VOOC ... VOCUNT," says the inscription.

It comes from the small neighbouring town of Vaison, where Pliny the naturalist ${ }^{2}$ sometimes spent a holiday. Here perhaps, at his host's table, the celebrated compiler

${ }^{1}$ The Vocontii were a nation of Gauls inhabiting the Viennaise, between the Allobroges on the north, the Caturiges and the estates of King Cottius on the east, the Cavares on the west and the Memini and Vulgientes on the south. Vasio (Vocontia), now Vaison, was their capital.-Translator's Note.

2 Caius Plinius Secundus $(23-79)$, known as Pliny the Elder, or the Naturalist, to distinguish him from his nephew Caius Plinius Cæcilius Secundus (6r-co-r15), commonly called Pliny the younger, the historian. He was the author of the famous Naturalis Historia.Translator's Note. 


\section{The Old Weevils}

learnt to appreciate the Beccafico, ${ }^{1}$ famous among the Roman epicures and still renowned to-day, under the name of Grasset, among our Provençal gastronomers. It is a pity that my bit of silver says nothing of these events, more memorable than any battle.

It shows on one side a head and on the other a galloping horse, all barbarously inaccurate. A child trying its hand for the first time with a sharp-pointed stone on the fresh mortar of the walls would produce no more shapeless design. No, of a surety, those bold Allobroges were no artists.

How greatly superior to them were the foreigners from Phocæa! Here is a

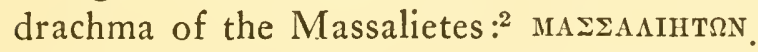
On the obverse, a head of Diana of Ephesus, chub-faced, full-cheeked, thick-lipped. A receding forehead, surmounted by a diadem; an abundant head of hair, streaming down the neck in a cascade of curls; heavy eardrops, a pearl necklace, a bow slung over the

1 The Garden Warbler, or Bush-pipet, a bird which is considered a great delicacy, especially in the autumn, when it feeds on figs, grapes and so on. Cf. The Hunting $W$ asps, by J. Henri Fabre, translated by Alexander Teixeira de Mattos: chap. xii.-Translator's Note.

2 From Massalia, the ancient name of Marseilles, of 


\section{The Life of the Weevil}

shoulder. Thus was the idol decked by the hands of the pious Syrian.

To tell the truth, it is not æsthetic. It is sumptuous, if you will, and preferable, after all, to the donkey's-ears which our modern beauties wear perched upon their heads. What a singular freak is fashion, so fertile in the means of uglification! Commerce knows nothing of loveliness, says this divinity of the traders; it prefers profit, embellished with luxury. So speaks the drachma.

On the reverse, a lion clawing the ground and roaring wide-mouthed. Not of to-day alone is the savagery that symbolizes power in the shape of some formidable brute, as though evil were the supreme expression of strength. The eagle, the lion and other marauders often figure on the reverse of coins. But reality is not sufficient; the imagination invents monstrosities: the centaur, the dragon, the griffin, the unicorn, the double-headed eagle.

Are the inventors of these emblems so greatly superior to the Redskin who celebrates the prowess of his scalping-knife with

which Phocxa, in Asia Minor, was the mother city.Translator's Note. 


\section{The Old Weevils}

a Bear's paw, a Falcon's wing or a Puma's tooth stuck in his hair? We may safely doubt it.

How preferable to these heraldic horrors is the reverse of our own silver coinage recently brought into circulation! It represents a sower who, with a nimble hand, at sunrise, fills the furrows with the good seed of thought. It is very simple and it is great; it makes us reflect.

The Marseilles drachma has for its sole merit its magnificent relief. The artist who made the dies was a master of the graver's tool; but he lacked the breath of inspiration. His chub-faced Diana is no better than a trollop.

Here is the NAMASAT of the Volscæ, which became the colony of Nîmes. Side by side, profiles of Augustus and of his minister Agrippa. The former, with his dour forehead, his flat skull, his acquisitive broken nose, inspires me with but little confidence, notwithstanding what gentle Virgil said of him : Deus nobis hac otia fecit. ${ }^{1}$ It is success that makes gods. Had he not succeeded in

1 "The god made these hours of leisure for us."Translator's Note. 


\section{The Life of the Weevil}

his criminal projects, Augustus the divine would have remained Octavius the scoundrel.

His minister pleases me better. He was a great mover of stones, who, with his building-operations, his aqueducts and his roads, came and civilized the rude Volscæ a little. Not far from my village a splendid road crosses the plain, starting from the banks of the Aygues, and climbs up yonder, tedious in its monotonous length, to cross the Sérignan hills, under the protection of a mighty oppidum, which, much later, became the old castle, the castelas. It is a section of Agrippa's Road, which joined Marseilles and Vienne. The majestic ribbon, twenty centuries old, is still frequented. We no longer see the little brown foot-soldier of the Roman legions upon it; in his stead we see the peasant going to market at Orange, with his flock of Sheep or his drove of unruly Porkers. Of the two I prefer the peasant.

Let us turn over our green-crusted penny. "COL. NEM.,"1 the reverse tells us. The inscription is accompanied by a Crocodile chained to a palm-tree from which hang

1 Colony of Nîmes. Nemansus was the Latin name of Nîmes.-Translator's Note. 


\section{The Old Weevils}

crowns. It is an emblem of Egypt, conquered by the veterans who founded the colony. The beast typifying the Nile gnashes its teeth at the foot of the familiar tree. It speaks to us of Antony, the Don Juan; it tells us of Cleopatra, whose nose, had it been an inch shorter, would have changed the face of the globe. Thanks to the memories which it awakens, the scalybacked reptile becomes a superb historical lesson.

In this way, the important lessons of the numismatics of metals might be continued for many a day and be constantly varied without departing from my immediate neighbourhood. But there is another science of numismatics, far superior and less costly, which, with its medals, the fossils, tells us the history of life. I refer to the numismatics of stones.

'My very window-sill, the confidant of bygone ages, talks to me of a vanished world. It is, literally speaking, an ossuary, whose every particle retains the imprint of past lives. That block of stone has lived. Prickly spines of Sea-urchins, teeth and vertebræ of fish, broken pieces of shells and 


\section{The Life of the Weevil}

fragments of madrepores form a conglomeration of dead existences. Examined stone by stone, my house would resolve itself into a reliquary, a rag-fair of ancient things that were once alive.

The rocky stratum from which we extract our building-materials in these parts covers with its mighty shell the greater portion of the neighbouring uplands. Here the quarryman has been digging for none knows how many centuries, perhaps since the time when Agrippa hewed Cyclopean blocks to form the stages and the face of the theatre at Orange. And here daily the pick-axe uncovers curious fossils. The most remarkable of these are teeth, still wonderfully polished in the midst of their rough matrix and as bright with enamel as in the fresh state. Some of them are formidable, three-cornered, finely jagged at the edges, almost as large as a man's hand. What a yawning gulf, a jaw armed with such a set of teeth in manifold rows, placed stepwise almost to the back of the gullet! What mouthfuls, snapped up and lacerated by those notched shears! You shiver at the mere thought of 


\section{The Old Weevils}

reconstructing that awful implement of destruction!

The monster thus equipped as a prince of death belonged to the family of the Squali. Paleontology calls him Carcharodon megalodon. Our modern Shark, the terror of the seas, gives an approximate idea of him, in so far as a dwarf can give an idea of a giant.

Other Squali, all ferocious gluttons, abound within the same stone. It contains Oxyrhinæ (O. xyphodon, AgAss.), whose jaws are furnished with curved and toothed Malay creeses; Lamix (L. denticulata, AgAss.), whose mouths bristle with sharp, flexuous daggers, flat on one side, convex on the other; and Notidani (N. primigenius, AGAss.), whose sunken teeth are crowned with radiating indentations.

This dental arsenal, bearing eloquent witness to bygone massacres, can hold its own with the Nîmes Crocodile, the Marseilles Diana or the Vaison Horse. With its panoply of carnage, it tells me how extermination came at all times to prune the excess of life; it says : 


\section{The Life of the Weevil}

"On the very spot where you stand meditating upon a splinter of stone, an arm of the sea once stretched, filled with war-like devourers and peaceful victims. A deep inlet occupied the future site of the Rhône valley. Its billows broke not far from your house."

Here in fact are the cliffs of the shore, in such a state of preservation that, when I concentrate my thoughts, I seem to hear the thunder of curving billows. Sea-urchins, Lithodomi, ${ }^{1}$ Petricolæ, ${ }^{2}$ Pholades ${ }^{3}$ have left their signatures upon the rock: hemispherical recesses large enough to contain one's fist; circular cells; cabins with a narrow opening through which the recluse received the incoming water, laden with food and constantly renewed. Sometimes the erstwhile occupant is there, mineralized, intact to the smallest details of his striæ, of his scales, a brittle ornamentation; more often he has disappeared, fallen into decay, and his house has filled with a fine sea-mud, hardened into a chalky kernel.

In this quiet inlet, collected by some eddy

${ }^{1}$ A form of Mussel.-Translator's Note.

'Another genus of bivalve mollucs.-Translator's Note. 3Piddocks.-Translator's Note. 


\section{The Old Weevils}

from the surrounding sea-bed and sunk to the bottom of the oozes, now turned into marl, there are stupendous deposits of shells, of every shape and size. It is a molluscs' burying-ground, with hills for tumuli. I dig up Oysters eighteen inches long and weighing five or six pounds apiece. One could scoop up from this enormous heap Scallops, Coni, ${ }^{1}$ 'Cytheres, ${ }^{2}$ Mactræ, ${ }^{3}$ Murices, ${ }^{4}$ Turritellæ, ${ }^{5}$ Mitræ $^{6}$ and others too numerous, too innumerable, to mention. You stand stupefied before the intense vitality of the days of old, which was able to supply us with such a mass of relics in a mere hole in the ground.

This necropolis of shells tell us also that time, that patient renewer of the harmony of things, has mown down not only the individual, a precarious being, but also the species. Nowadays the neighbouring sea,

${ }^{1} \mathrm{Or}$ Cone-shells. - Translator's Note.

${ }^{2}$ Bivalved Ostracods.-Translator's Note.

${ }^{3} \mathrm{~A}$ genus of molluses including the Surf Clams and related species.-Translator's Note.

${ }^{4}$ Gastropods with a rough, spinose shell.-Translator's Note.

${ }^{5}$ Gastropods with an elongated, turreted shell.-Translator's Note.

'Or Mitre-shells. Gastropods with a fusiform shell suggesting a bishop's mitre.-Translator's Note. 


\section{The Life of the Weevil}

the Mediterranean, contains hardly anything identical with the population of the vanished gulf. To find a few features of resemblance between the present and the past, we should have to seek them in the tropical seas.

The climate therefore has become colder; the sun is slowly approaching extinction; the species are dying out. Thus I am told by the numismatics of my stone window-sill.

Without leaving my field of observation, so modest and restricted and yet so rich, let us once more consult the stone and this time on the subject of the insect. The country around Apt abounds in a curious rock that breaks off in flakes, not unlike sheets of whity-grey cardboard, which burn with a sooty flame and a bituminous smell. It was deposited at the bottom of the great lakes haunted by Crocodiles and giant Tortoises. Those lakes were never beheld by human eye. Their basins have been replaced by the range of the hills; their muds, slowly deposited in thin layers, have become mighty ridges of stone.

Let us remove a slab and subdivide it into flakes with the point of a knife, a task as easy as separating the superimposed sheets 


\section{The Old Weevils}

of a piece of paste-board. In so doing we are examining a volume taken from the library of the mountains; we are turning the pages of a magnificently illustrated book. It is a manuscript of nature, far superior to any Egyptian papyrus. On almost every page are diagrams, nay better, realities converted into pictures.

Here is a page of fish, grouped at random. One might take them for a dish fried in oil. Backbone, fins, vertebral column, the little bones of the head, the crystalline lens turned into a black globule: all is there, in its natural arrangement. One thing alone is absent: the flesh. No matter: our dish of gudgeons looks so good that we feel tempted to scratch a bit off with our finger and taste this supersecular preserve. Let us indulge our fancy and put between our teeth a morsel of this mineral fry seasoned with petroleum.

There is no inscription to the picture. Reflection makes good the deficiency. It tells us :

"These fish lived here, in large numbers, in peaceful waters. Suddenly a spate came, asphyxiating them in its mud-thickened torrent. Buried forthwith in the mire and thus 


\section{The Life of the Weevil}

rescued from the agents of destruction, they have endured through time and will endure indefinitely, under the cover of their winding-sheet."

The same flood brought from the adjacent rain-swept shores a host of refuse, both vegetable and animal, so much so that the lacustrian deposit tells also of things on land. It is a general record of the life of the time.

Let us turn a page of our slab, or rather of our album. Here are winged seeds, leaves outlined in brown impressions. The stone herbal rivals the botanical clearness of our ordinary herbals. It repeats what the shells have already taught us: the world is changing, the sun is losing its strength. The vegetation of modern Provence is not what it was in the old days; it no longer includes palm-trees, laurels oozing with camphor, tufted araucarias and many other trees and shrubs whose equivalents belong to the torrid regions.

Continue to turn the pages. We now come to insects. The most frequent are Diptera, of moderate size, often very humble Flies and Gnats. The teeth of the great Squali surprised us by their smooth polish 


\section{The Old Weevils}

amid the roughness of their chalky matrix. What shall we say of these frail Midges enshrined intact in their marly reliquary? The feeble creature, which our fingers could not pick up without crushing it, remains undisturbed beneath the weight of the mountains! The six slender legs, which the least touch is enough to disjoint, lie spread upon the stone, correct in shape and arrangement, in the attitude of the insect at rest. There is nothing lacking, not even the tiny double claws at the end of the tarsi. Here are the two wings, unfurled. The fine network of their veins can be studied under the lens as clearly as in the Fly of our collections, stuck on a pin. The antennary plumes have lost none of their fragile grace; the abdomen gives us the number of the segments, edged with a row of specks which once were cilia.

Even the carcase of a Mastodon, defying time in its sandy bed, fills us with amazement; a Gnat of exquisite delicacy, preserved intact in the thickness of the rock, staggers our imagination.

Certainly, the Mosquito, borne along by the floods, did not come from far away. Before he arrived, some turbulent streamlet 


\section{The Life of the Weevil}

must have reduced him to the nothingness to which he was already so near. Slain by the joys of a morning-a long life for a Gnat -he fell from the top of his reed, was straightway drowned and disappeared in the muddy catacombs.

Who are these others, these dumpy creatures, with hard, convex wing-cases, which next to the Flies are the most numerous. Their small heads, prolonged into a snout, tell us beyond dispute. They are proboscidian Beetles, Rhynchophoræ, or, in simpler terms, Weevils. There are small ones, middling ones, large ones, similar in dimensions to their counterparts of to-day.

Their position on the limestone slab is not as correct as the Mosquito's. The legs are entangled anyhow; the beak, the rostrum, is now hidden under the breast, now projects forward. Some display it in profile; others -more frequent these-stretch it to one side, as the result of a twisted neck. These contorted insects, with their dislocated members, did not receive the swift and peaceful burial of the Flies. Though sundry of them may have lived on the plants by the shore, the others, the majority, come from the I6 


\section{The Old Weevils}

surrounding parts, carried by the rain-water, which warped their joints in crossing such obstacles as twigs and stones. A suit of armour has kept the body unscathed, but the delicate articulations of the members have given way to some extent; and the muddy winding-sheet received the drowned Beetles as the ravages of the journey left them.

These strangers, coming perhaps from afar, supply us with valuable information. They tell us that, if the shores of the gulf had the Mosquito as chief representative of the insect class, the woods had the Weevil.

Apart from the snout-bearing family, the pages of my Apt rock show me scarcely anything else, especially in the order of the Beetles. Where are the other terrestrial groups, the Carabus, ${ }^{1}$ the Dung-beetle, ${ }^{2}$ the Capricorn, ${ }^{3}$ whom the wash of the rains, indifferent as to its harvest, would have brought to the lake even as it did the

${ }^{1}$ Or Ground-beetle. Cf. The Glow-quorm and Other Beetles, by J. Henri Fabre, translated by Alexander Teixeira de Mattos: chap. xiii-CTranslator's Note.

2 Cf. The Sacred Beetle and Others, by J. Henri Fabre, translated by Alexander Teixeira de Mattos: passim.Translator's Note.

${ }^{3}$ Cf. The Glow-worm and Other Beetles: chap. viii.Translator's Note. 


\section{The Life of the Weevil}

Weevil? There is not the least vestige of those tribes, so prosperous to-day.

Where are the Hydrophilus, ${ }^{1}$ the Gyrinus, ${ }^{2}$ the Dytiscus, ${ }^{3}$ all inhabitants of the water? These lacustrians had every chance of being handed down to us as mummies between two sheets of marl. If there were any in those days, they used to live in the lake, whose mud would have preserved these horn-clad insects even more effectually than the little fishes and more especially the Fly. Well, of these aquatic Beetles there is no trace either.

Where were they, where were those who are missing from the geological reliquary? Where were the inhabitants of the thickets, of the greenswards, of the worm-eaten treetrunks: Capricorns, borers of wood; Sacred Beetles, workers in dung; Carabi, disembowellers of game? One and all were in the limbo of the time to come. The present of that period did not possess them; the future awaited them. The Weevil, if I may credit

1 The Great Water-beetle. Cf. The Glow-worm and Other Beetles: chap. X.-Translator's Note.

2 The Whirligig Beetle. Cf. The Life of the Fly, by J. Henri Fabre, translated by Alexander Teixira de Mattos: chap. vii.-Translator's Note.

${ }^{3}$ A carnivorous Water-beetle. Cf. idem: chaps. vii and viii.-Translator's Note. 


\section{The Old Weevils}

the modest records which I am able to consult, must therefore be the oldest of the Beetles.

In the beginning, life fashioned oddities which would be screaming discords in the present harmony of things. When it invented the saurian, it revelled at first in monsters from fifteen to twenty yards long. It placed horns upon their noses and above their eyes, paved their backs with fantastic scales and hollowed their necks into spiny pouches wherein their heads withdrew as into a hood. It even tried, though with no great success, to give them wings. After these horrors, the procreating ardour calmed down and produced the charming Green Lizard of our hedges.

When it invented the bird, it filled its beak with the reptile's pointed teeth and suspended from its rump a long, featherclad tail. These indeterminate and revoltingly hideous creatures were the distant prelude to the Robin Redbreast and the Dove.

All these primitives are noted for a very small skull, an idiot's brain. The prehistoric animal is first and foremost an atrocious 


\section{The Life of the Weevil}

machine for grabbing, with a stomach for digesting. The intellect does not count as yet. That will come later.

The Weevil, in his fashion, repeats these aberrations to a certain extent. See the extravagant appendage to his little head. It is here a short, thick snout; there a sturdy beak, round or cut four-square; elsewhere a foolish reed, thin as a hair, long as the body and longer. At the tip of this egregious instrument, in the terminal mouth, are the fine shears of the mandibles; on either side, the antennæ, with their first joints fitting into a groove.

What is the use of this beak, this snout, this caricature of a nose? Where did the insect find the model for it? Nowhere. The Weevil invented it and retains the monopoly. Outside his family, no Beetle indulges in these nasal eccentricities.

Observe also the smallness of the head, a bulb that hardly swells beyond the base of the snout. What can it have inside? A very poor nervous equipment, the sign of exceedingly limited instincts. Before seeing them at work, we have a poor opinion of the intelligence of these microcephalics; we 


\section{The Old Weevils}

class them among the obtuse, among creatures deprived of industry. These surmises will not be greatly belied.

Though the Weevil be but little glorified by his talents, this is no reason for despising him. As we learn from the lacustrian schists, he was in the van of the insects with the armoured wing-cases; he was long stages ahead of those which were working out new forms within the limits of the possible. He speaks to us of primitive shapes, sometimes so quaint; he is in his own little world what the bird with the toothed mandibles and the saurian with the horned eyebrows are in a higher world.

In ever-thriving legions, he has come down to us without changing his characteristics. $\mathrm{He}$ is to-day as he was in the youth of the continents: the pictures on the chalky slates proclaim the fact aloud. Under any such picture I would venture to write the name of the genus, sometimes even of the species.

Permanence of instinct must go with permanence of form. B.y consulting the modern Weevil we shall therefore obtain a chapter closely approximate to the biology of his predecessors at the time when Provence 


\section{The Life of the Weevil}

was a land of great lakes shaded by palmtrees and filled with Crocodiles. The history of the present will teach us the history of the past. 


\section{CHAPTER II}

\section{THE SPOTTED LARINUS}

ARINUS is a vague term, which cannot
teach us anything. The word sounds well. It is something not to afflict the ear with raucous spittings; but the prentice reader wants more than this. $\mathrm{He}$ expects the name to give him, in euphonious syllables, a brief description of the insect named. This would help to guide him in the midst of the vast multitude.

I cordially agree with him, while recognizing what an arduous task it would be to devise a rational nomenclature that would give the beasts the forenames and surnames which they deserve. Our ignorance condemns us to be vague and often nonsensical. Let us consider a case in point.

What does Larinus mean? The Greek

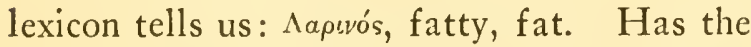
insect which is the subject of this chapter any right to such a description? Not at all. 


\section{The Life of the Weevil}

It is corpulent, I agree, as are the Weevils generally, but does not more than another deserve a certificate of obesity.

Let us look a little deeper. Aapós means pleasant to the taste, pleasant to the eye, dainty, sweet. Are we there now? Not yet. To be sure, the Larinus is not without daintiness, but how many among the longnosed Beetles excel him in beauty of costume! Our osier-beds provide nourishment for some that are flecked with flowers of sulphur, some that are laced with Chinese white, some that are powdered with malachite-green. They leave on our fingers a scaly dust that looks as though it were gathered from a Butterfly's wing. Our vines and poplar-trees have some that surpass copper pyrites in metallic lustre; the equatorial countries furnish specimens of unparalleled magnificence, true gems beside which the marvels of our jewel-cases would pale. No, the modest Larinus has no right to be extolled as superb. The title of dandy must be awarded to others, in the beakbearing family, rather than to him.

If his godfather, better-informed, had named him after his habits, he would have 


\section{The Spotted Larinus}

called him an artichoke-thief. The group of the Larini, in fact, establishes its offspring in the fleshy base of the flowers of the Carduacex, the thistle, the cotton-thistle, the centaury, the carline thistle and others, which, in structure and flavour, recall more or less remotely the artichoke of our tables. This is its special province. The Larinus is charged with the thinning out of the fierce, encroaching thistle.

Glance at the pink, white or blue heads of a Carduacea. Long-beaked insects swarm, awkwardly diving into the mass of florets. What are they? Larini. Open the head, split its fleshy base. Surprised by the air and by the light, plump, white, legless grubs sway to and fro, each isolated in a small recess. What are these grubs? Larinus. larvæ.

Here accuracy:calls for a reservation. A few other Weevils, related to those whose history we are considering, are also partial, on behalf of their family, to the fleshy receptacles with the artichoke flavour. No matter: the species that take the lead in numbers, frequency and handsome proportions are the authorized exterminators of 


\section{The Life of the Weevil}

the thistle-heads. Now the reader knows as much as I can tell him.

All the summer, all the autumn, until the cold weather sets in, the most ornamental of our southern thistles grows profusely by the road-side. Its pretty, blue flowers, gathered into round, prickly heads, have won it the botanical name of Echinops, in allusion to the Hedgehog rolled into a ball. It is indeed like a Hedgehog. Better still: it is like a Sea-urchin stuck upon a stalk and turned into an azure globe.

Beneath a screen of star-shaped flowerets the shapely tuft hides the thousand daggers of its scales. Whosoever touches it with an incautious finger is surprised to encounter such aggressiveness beneath an innocent appearance. The leaves that go with it, green above, white and fluffy underneath, do at least warn the inexperienced: they are divided into pointed lobes, each of which bears an extremely sharp needle at its tip.

This thistle is the patrimony of the Spotted Larinus (L. maculosus, ScH.), whose back is powdered with cloudy yellow patches. The Weevil browses very sparingly on the leaves. June is not yet over 


\section{The Spotted Larinus}

before she is exploiting the heads, green at this time and the size of peas, or at most of cherries, with a view to establishing her family. For two or three weeks the work of colonization continues on globes which grow bluer and larger day by day.

Couples are formed, very peaceably, in the glad morning sunlight. The nuptial preliminaries, resembling the embraces of jointed levers, display a rustic awkwardness. With his fore-legs the male Weevil masters his spouse; with his hinder tarsi, gently and at intervals, he strokes her sides. Alternating with these soft caresses are sudden jolts and impetuous jerks. Meanwhile, the object of these attentions, in order to lose no time, works at the thistle-head with her beak and prepares the lodging for her egg. Even in the midst of her wedding the care of the family leaves this laborious insect no repose.

What precisely is the use of the Weevil's rostrum, this paradoxical nose, such as no carnival murmur would venture to wear? We shall find out at leisure, taking our own time.

My prisoners, enclosed in a wire-gauze cover, are working in the sunlight on my 


\section{The Life of the Weevil}

window-sill. A couple has just broken apart. Careless of what will happen next, the male retires to browse for a while, not on the blue thistle-heads, which are choice morsels reserved for the young, but on the leaves, where a superficial scraping enables the beak to remove some frugal mouthfuls. The mother remains where she is and continues the boring already commenced.

The rostrum is driven right into the ball of florets and disappears from sight. The insect hardly moves, taking at most a few slow strides now in one direction, now in another. What we see is not the work of a gimlet, which twists, but of an awl, which sinks steadily downwards. The mandibles, the sharp shears affixed to the implement, bite and dig; and that is all. In the end, the rostrum used as a lever, that is to say, bending upon its base, uproots and lifts the detached florets and pushes them a little way outwards. This must cause the slight unevenness which we perceive at any inhabited point. The work of excavation lasts a good quarter of an hour.

Then the mother turns about, finds the 28 


\section{The Spotted Larinus}

opening of the shaft with the tip of her belly and lays the egg. But how? The pregnant insect's abdomen is far too large and too blunt to enter the narrow passage and deposit the egg directly at the bottom. A special tool, a probe carrying the egg to the point required, is therefore absolutely needed here. But the insect does not possess one that shows; and things take place so swiftly and discreetly that I see nothing of that kind unsheathed.

No matter, I am positively convinced of it: to place the egg at the bottom of the shaft which the rostrum has just bored, the mother must possess a guide-rod, a rigid tube, kept in reserve, invisible, among her tools. We shall return to this curious subject when more conclusive instances arise.

One first point is gained: the Weevil's rostrum, that nose which at first sight was deemed grotesque, is in reality an instrument of maternal love. The extravagant becomes the everyday, the indispensable. Since it carries mandibles and other mouth-parts at its tip, its function is to eat, that is selfevident; but to this function is added another 


\section{The Life of the Weevil}

of greater importance. The fantastic stylet prepares the way for the eggs; it is the oviduct's collaborator.

And this implement, the emblem of the guild, is so honourable that the father does not hesitate to sport it, though himself incapable of digging the family cells. Like his consort, he too carries an awl, but a smaller one, as befits the modesty of his rôle.

A second point becomes clear. In order to insert the egg at convenient points, it is the rule for the insect to possess an implement with two functions, an implement which at the same time opens the passage and guides the eggs along it. This is the case with the Cicada, ${ }^{1}$ the Grasshopper, ${ }^{2}$ the Saw-fly; the Leucospis ${ }^{3}$ and the Ichneumon$\mathrm{fly},{ }^{4}$ all of whom carry a sabre, a saw or a probe at the tip of the abdomen.

The Weevil divides the work and appor-

${ }^{1} \mathrm{Cf}$. The Life of the Grasshopper, by J. Henri Fabre, translated by Alexander Teixeira de Mattos: chapters i. to v.-Translator's Note.

${ }^{2}$ Cf. idem: chapter xiv. and passim.-Translator's Note. ${ }^{3} \mathrm{Cf}$. The Life of the Fly: chapter iii.-Translator's Note. ${ }^{4} \mathrm{Cf}$. The Life of the Caterpillar, by J. Henri Fabre, translated by Alexander Teixeira de Mattos: chapter xiv., in which the activities of one of the Ichneumon-flies, Microgaster glomeratus, are described.-Translator's Note. 


\section{The Spotted Larinus}

tions it between two implements, one of which, in front, is the perforating augur and the other, behind, hidden in the body and unsheathed at the moment of the laying, is the guiding tube. Except in the Weevils, this curious mechanism is unknown to me.

When the egg is placed in position-and this is quickly done, thanks to the preliminary work of the drill-the mother returns to the point colonized. She packs the disturbed materials a little, she lightly pushes back the uprooted florets; then, without taking further trouble, she goes away. She sometimes even dispenses with these precautions.

A few hours later, I examine the heads exploited, which may be recognized by a certain number of faded and slightly projecting patches, each of which shelters an egg. With the point of my penknife I extract the little, faded bundle and open it. At the base, in a small round cell, hollowed out of the substance of the central globule, the receptacle of the thistle-head, is the egg, fairly large, yellow and oval.

It is enveloped in a brown substance derived from the tissues injured by the mother's augur and from the exudations of 


\section{The Life of the Weevil}

the wound, which have set like cement. This envelope rises into an irregular cone and ends in the withered florets. In the centre of the tuft we generally see an opening, which might well be a ventilating-shaft.

The number of eggs entrusted to a single head may easily be ascertained without destroying the cells: all that we need do is to count the yellow blurs unevenly distributed over the blue background. I have found five, six and more, even in a head smaller than a cherry. Each covers an egg. Do all these eggs come from the same mother? It is possible. At the same time, they may be of diverse origin, for it is not unusual to surprise two mothers both occupied in laying eggs on the same globe.

Sometimes the points worked upon almost touch. The mother, it seems, has a very restricted numerical sense and is incapable of keeping count of the occupants. She drives her probe into the florets, unheeding that the place beside her is already taken. As a rule there are too many, far too many feasters at the niggardly banquet of the blue thistle. Three at most will find enough to live on. The first-comers will thrive; the laggards 


\section{The Spotted Larinus}

will perish for lack of room at the common table.

The grubs are hatched in a week: little white atoms with red heads to them. Suppose them to be three in number, as frequently happens. What have the little creatures in their larder? Next to nothing. The echinops is an exception among the Carduaceæ. Its flowers do not rest upon a fleshy receptacle expanded into a heart, like the artichoke's. Let us open one of the heads. In the centre, as a common support, is a round firm nucleus, a globe hardly as large as a peppercorn, fixed on the top of a little column which is a continuation of the axis of the stem. That is all.

A scanty, a very scanty provision for three consumers. In bulk there is not enough to furnish the first few meals of a single grub; still less is there enough-for it is very tough and unsubstantial - to provide for those fine layers of fat which make the grub look as sleek as butter and are employed as reserves during the transformation.

Nevertheless, it is in this paltry globule and the small column which supports it that the three boarders find, their whole life long, 


\section{The Life of the Weevil}

the wherewithal to feed and grow. Not a bite is given elsewhere; and even so the attack is delivered with extreme discretion. The food is rasped and nibbled on the surface and not completely consumed.

To make much out of nothing, to fill three starveling bellies, sometimes four, with a single crumb, would be out of the question. The secret of the food-supply is not contained in the small amount of solid matter that has disappeared. Let us look into this more closely.

I take out a few larvæ which are already fairly well-grown and install dwellings and dwellers in glass tubes. For a long time, with my pocket-lens, I watch the prisoners. I cannot see that they bite into the central knob, which is already damaged, nor the axis, which also has been cut into. From these surfaces, which have been scored since I know not how long; from what appeared to be their daily bread, their mandibles remove not the smallest particle. At most the mouth is applied for a moment to the surface; then it is withdrawn, uneasy and disdainful. It is evident that the ligneous fare, though still quite fresh, does not suit. 


\section{The Spotted Larinus}

The proof is completed by the final result of my experiments. In vain I keep the thistle-heads fresh in glass tubes, plugged with a stopper of wet cotton-wool: my attempts at rearing are not once crowned with success. As soon as the head is removed from the plant, its inhabitants begin to die of starvation, whether I intervene or whether I do not. They all pine away in the heart of their native globe and at last perish, no matter in what receptacle-testtube, flask or tin box-I place my collection. Later, on the other hand, when the feedingperiod is over, I shall find it very easy to keep the grubs in good condition and to follow at will their preparations for the nymphosis.

This failure tells me that the larva of the Spotted Larinus does not sustain itself with solid food; it prefers the clear broth of the sap. It taps the cask of its azure cellar, that is to say, it makes a careful gash in the axis of the head as well as in the central nucleus.

From these surface wounds, which are kept open by fresh strokes of the plane as soon as a dry scab forms upon them, it laps 


\section{The Life of the Weevil}

the sap of the thistle, which oozes up from the roots. As long as the blue globe is on its stalk, very much alive, the sap ascends, the broached casks exude their contents and the grub sips the nourishing draught. But, once detached from the stem, cut off from its source of supply, the cellar runs dry. Thereupon the larva promptly dies. This explains the fatal catastrophe of my attempts to rear it.

All that the Larinus-larvæ need is to lick the exudations from a wound. The method employed is henceforth obvious. The newborn grubs, hatched upon the central globe, take their places around its axis, proportioning the distance between them to the number of guests. Each of them peels and slashes with its mandibles the part in front of it, causing the nutritious moisture to exude. If the spring dies up through healing, fresh bites revive it.

But the attack is made with circumspection. The central column and its circular capital form the mainstay of the globe. If too extensively injured, the scaffolding would bend before the wind and bring down the dwelling. Moreover, the conduits of the 


\section{The Spotted Larinus}

aqueduct must be respected, if a suitable supply of sap is to be provided until the end. Accordingly, whether three or four in number, the grubs abstain from rasping the surface too deeply.

The cuts, which amount to no more than a judicious paring of the surface, imperil neither the solidity of the structure nor the action of the vessels, so that the blossoms, their plunderers notwithstanding, retain a very healthy appearance. They expand as usual, except that the pretty, blue ground is stained with yellow patches, which grow wider from day to day. At each of these points, a grub is established under the cover of the dead florets. Each blemish marks one diner's seat at table.

The florets, as we said, have for their common support, for their receptacle, the round knob surmounting the axis. It is on this globule that the grubs begin. They attack a few of the florets at their base, uprooting them without injuring them and thrusting them upwards with a heave of the back. The spot thus cleared is slightly broken into and hollowed out and becomes the first refreshment-bar. 


\section{The Life of the Weevil}

What becomes of the items removed? Are they thrown to the ground as inconvenient rubbish? The tiny creature is careful not to do anything of the kind, which would mean exposing its plump back, a small but enticing morsel, to the eyes of the foe.

Pushed back, the materials cleared away remain intact, still clustered together in their natural position. Not a flake, not a chip falls to earth. By means of a quick-setting, rain-proof glue, the whole of the fragments detached are cemented to the base in a continuous sheaf, so that the blossom is kept intact, save for the yellowish tint of the parts wounded. As the grub increases in size, more florets are cut away and take their place, beside the others, in the roof, which swells by degrees and ends by bulging out.

Thus a quiet dwelling is obtained, sheltered from wind and weather and the heat of the sun. Within, the hermit sips at his cask in safety; he waxes big and fat. I suspected it, that the larva would be able to make up by its own industry for the rough and ready installation of the egg! Where maternal care is lacking, the grub possesses special talents as a safeguard. 


\section{The Spotted Larinus}

Nevertheless, nothing in the grub of the Spotted Larinus reveals the skilful builder of thatched huts. It is a little sausage of a creature, a rusty yellow in colour and bent into a hook. There is not a vestige of legs; the whole equipment consists of the mouth and the opposite end, an active auxiliary. What can this little roll of rancid butter be capable of doing? To observe it at work is easy enough at the propitious moment.

In the middle of August, when the larva, having achieved its full growth, is busy strengthening and plastering its abode in view of the approaching nymphosis, I half-open a few cells. The hulls opened, but still adhering to the natal blossom, are arranged in a row in a glass tube which will enable me to watch the work without disturbing the worker. I have not long to wait for the result.

In a state of repose, the grub is a hook with the extremities very near together. From time to time I see it bring the two ends into intimate contact and close the circuit. Then-do not let us be shocked by the grub's procedure: this would mean misconceiving life's sacred simplicities-then 


\section{The Life of the Weevil}

with its mandibles it very neatly gathers from the stercoral orifice a tiny drop the size of an ordinary pin's head. It is a muddy white liquid, flowing like gum, similar in appearance to the resinous beads that ooze from the horned galls of the turpentine-tree when you break them.

The grub spreads its little drop over the edges of the breach made in its dwelling; it distributes it here and there, very sparingly; it pushes and coaxes it into the gaps. Then, attacking the adjacent florets, it picks out the shreds and chips and bits of hairs.

This does not satisfy it. It rasps the axis and the central nucleus of the blossom, detaching tiny scraps and atoms. A laborious task, for the mandibles are short and cut badly. They tear rather than slice.

All this is distributed over the still fresh cement. This done, the grub bestirs itself most strenuously, bending into a hook and straightening out again; it rolls and glides about its cabin to make the materials amalgamate and to smooth the wall with the pad of its round rump.

When this pressing and polishing is finished, the larva once more curves into a 


\section{The Spotted Larinus}

circle. A second white drop appears at the factory-door. The mandibles take hold of the ignominious product as they would of an ordinary mouthful; and the process is repeated as before: the cell is first smeared with glue and then encrusted with ligneous particles.

After thus expending a certain number of trowelfuls of cement, the grub remains motionless; it seems to be abandoning a job too much for its means. Twenty-four hours later, the open hulls are still gaping. An attempt has been made to repair the cell, but not to close it thoroughly. The task is too heavy.

What is lacking? Not the ligneous materials, which can always be obtained from the grub's surroundings, but the adhesive cement, the factory having closed down. And why has it closed down? The answer is quite simple: because the vessels of the thistlehead detached from its stalk are dry and can no longer furnish the food upon which everything depends.

The curly-bearded Chaldean used to build with bricks of mud baked in the kiln and cemented with bitumen. The Weevil of the 


\section{The Life of the Weevil}

blue thistle possessed the secret of asphalt long before man did. Better still: to put its method into practice with a rapidity and economy unknown to the Babylonian contractors, it had and still has its own well of bitumen.

What can this viscous substance be? As I have explained, it appears in opal drops at the waste-pipe of the intestine. Becoming hard and resinous on contact with the air, it turns a tawny red, so much so that the inside of the cell looks at first as though coated with quince-jelly. The final hue is a dullbrown, against which pale specks of mixed ligneous refuse stand out sharply.

The first idea that occurs to one's mind is that the Weevil's glue must be some special secretion, not unlike silk, but emerging from the opposite pole. Can there be actually glands secreting a viscous fluid in the grub's hinder part? I open a larva which is busily building. Things are not as I imagined: there is no glandular apparatus attached to the lower end of the digestive canal.

Nor is there anything to be seen in the ventricle. Only the Malpighian tubes, which are rather large and four in number, reveal, 


\section{The Spotted Larinus}

by their opaline tint, the fact that they are fairly full; while the lower portion of the intestine is dilated with a pulpy substance which conspicuously attracts the eye.

It is a semi-fluid, viscous, treacly material of a muddy white. I perceive that it contains an abundance of opaque corpuscles, like finely powdered chalk, which effervesce when dissolved in nitric acid and are therefore uric products.

This very soft pulp is, beyond a doubt, the cement which the grub ejects and collects drop by drop; and the rectum is obviously the bitumen-warehouse. The parity of aspect, colour and treacly consistency are to me decisive: the grub consolidates and cements and creates a work of art with the refuse from its sewer.

Is this really an excremental residue? Doubts may be permitted. The four Malpighian tubes which have poured the powdered urates into the intestine might well supply it with other materials. They do not in general seem to perform very exclusive duties. Why should they not be entrusted with various functions in a poorly-equipped organism? They fill with a chalky broth to 


\section{The Life of the Weevil}

enable the Capricorn's larva to block the doorway of its cell with a marble slab. It would not be at all surprising if they were also gorged with the viscous fluid that becomes the asphalt of the Larinus.

In this embarrassing instance, the following explanation may possibly suffice. The Larinus' larva observes, as we know, a very light diet, consisting of sap instead of solid food. Therefore there is no coarse residue. I have never seen any dirt in the cell; its cleanliness is perfect.

This does not mean that all the nourishment is absorbed. There is certainly refuse of no nutritive value, but it is thin and almost fluid. Can this be the pitch that cements and stops up the chinks? Why not? If so, the grub would be building with its excrement; with its ordure it would be making a pretty home.

Here we must silence our repugnance. Where would you have the recluse obtain the material for its casket? Its cell is its world. It knows nothing beyond that cell; nothing comes to its assistance. It must perish if it cannot find its store of cement within itself. Various caterpillars, not rich enough to 


\section{The Spotted Larinus}

afford the luxury of a perfect cocoon, have the knack of felting their hairs with a little silk. The Larinus-grub, that povertystricken creature, having no spinning-mill, must have recourse to its intestine, its only stand-by.

This stercoral method proves once more that necessity is the mother of invention. To build a luxurious palace with one's ordure is a most meritorious device. Only an insect would be capable of it. For that matter, the Larinus has no monopoly of this architectural style, which is not described in Vitruvius. ${ }^{1}$ Many other larvæ, betterfurnished with building-materials-those of the Onites, the Onthophagi, ${ }^{1}$ the Cetoniæ, ${ }^{1}$ for example-greatly excel it in the beauty of their excremental edifices.

When completed, on the approach of the nymphosis, the abode of the Larinus is an oval cell measuring fifteen millimetres in

1 Marcus Vitruvius Pollio ( $f$. Ist century в. c.) the Roman architect and engineer, author of $D_{e}$ Architectura.Translator's Note.

${ }^{1}$ For the Onitis and Onthophagus Dung-beetles, lcf. The Sacred Bectles and Others: chapters xi. and xiv. to xviii. - Translator's Note.

${ }^{2}$ Rose-chafers. Cf. More Hunting Wasps: chap. iv.Translator's Note. 


\section{The Life of the Weevil}

length by ten in width. ${ }^{1}$ Its compact structure almost enables it to resist the pressure of the fingers. Its main diameter runs parallel with the axis of the thistle-head. When, as is not unusual, three cells are grouped on the same support, the whole is not unlike the fruit of the castor-oil-plant, with its three shaggy husks.

The outer wall of the cell is a rustic bristle of chips and hairy debris and above all of whole florets, faded and yellow, torn from their base and pushed out of place while retaining their natural arrangement. In the thickness of the wall the cement predominates. The inner wall is polished, washed with a red-brown lacquer and sprinkled with an incrustation of ligneous fragments. Lastly, the pitch is of excellent quality. It makes a solid wall of the work; and, moreover, it is impervious to moisture: when immersed in water, the cell does not permit any to pass through to the interior.

In short, the Larinus' cell is a comfortable dwelling, endowed, in the beginning, with the pliancy of soft leather, which allows free scope for the growing-process; then, thanks

3.585 by .39 inch. - Translator's Note. 


\section{The Spotted Larinus}

to the cement, it hardens into a shell permitting the peaceful somnolence of the transformation. The flexible tent of the early days becomes a stout manor-house.

Here, I told myself, the adult would pass the winter, protected against the damp, which is more to be dreaded than the cold. I was wrong. By the end of September, most of the cells are empty, though their support, the blue thistle, eager to open its last blooms, is still in fairly good condition. The Weevils have gone, in all the freshness of their floured costume; they have broken out through the top of their cells, which now gape like broken pitchers. A few loiterers still lag behind at home, but are quite ready to make off, judging by their agility when my curiosity chances to set them free.

When the inclement months of December and January have arrived, I no longer find a single cell inhabited. The whole population has migrated. Where has it taken refuge?

I am not quite sure. Perhaps in the heaps of broken stones, under cover of the dead leaves, in the shelter of the tufts of grass that grow beneath the hawthorn in the hedges. For a Weevil the country-side is 


\section{The Life of the Weevil}

full of winter-resorts. We need not be anxious about the emigrants; they are well able to look after themselves.

None the less, in the face of this exodus, my first impression is one of surprise. To leave such an excellent lodging for a casual shelter, of doubtful safety, seems to me a rash and ill-advised expedient. Can the insect be lacking in prudence? No; it has serious motives for decamping as quickly as possible when the autumn draws to an end. Let me explain matters.

In the winter the echinops is a brown ruin which the north-wind tears from its hold, flings on the ground and reduces to tatters by rolling it in the mud of the roads. A few days of bad weather turn the handsome blue thistle into a mass of lamentable decay.

What would become of the Weevil on this support, now the plaything of the winds? Would her tarred cask resist the assaults of the storm? Would she survive rolling over the rough soil and prolonged steeping in the puddles of melted snow?

The Weevils foreknow the dangers of a crazy support; warned by the almanack of instinct, they foresee the winter and its mis48 


\section{The Spotted Larinus}

eries. So they move house while there is yet time; they leave their cells for a stable shelter where they will no longer have to fear the vicissitudes of a dwelling blown along the ground at random.

The desertion of the casket is not a sign of rash haste on the part of the Larinus: it shows a clear perception of coming events. In fact, a second Larinus will teach us presently that, when the support is safe and solidly rooted in the ground, the natal cell is not deserted until the return of the fine weather.

In conclusion, I ought perhaps to mention an apparently insignificant, but very exceptional fact, which I have only once observed in my dealings with the Spotted Larinus. Considering the scarcity of authentic data as to what becomes of instinct when the conditions of life are altered, we should do wrong to neglect these trifling discoveries.

Making ample allowance for anatomy, a precious aid, what do we know of animals? Next to nothing. Instead of inflating cabbalistic bladders with this nothing, let us collect well-observed facts, however humble. From a sheaf of such facts a clear, calm light 


\section{The Life of the Weevil}

may shine forth one day, a light far preferable to the fireworks of theories which dazzle us for a moment only to leave us in blacker darkness.

Here is this little detail. By some accident an egg has fallen from the blue globe, its regular lodging, into the axilla of a leaf half-way up the stem. We can even admit, if we choose, that the mother, either by inadvertence or by intention, laid it at this point herself. What will become of the egg under such conditions, so far removed from the rules? What I have before my eyes tell us.

The grub, faithful to custom, has not failed to broach the stem of the thistle, which allows the nourishing moisture to ooze from the wound. As a defence it has built itself a. pitcher similar in shape and size to that which it would have obtained in the thistlehead. This novel edifice lacks only one thing: the roof of dead florets bristling on the customary hut.

The builder has contrived to do very well without its floral pantiles. It has made use of the base of the leaf, one lobe of which is involved, as a support, in the wall of the 


\section{The Spotted Larinus}

cell; and from both leaf and stalk it has taken the ligneous particles which it had to imbed in the cement. In short, except that it is bare instead of surrounded with a palisade, the fabric adhering to the stalk does not differ from that hidden beneath the withered florets of the thistle-head.

People set great store by environment as a modifying agent. Well, here we see this famous environment at work. An insect is placed as much out of its element as it can be, but without leaving the food-plant, which would inevitably be the end of it. Instead of a ball of close-packed flowers it has for its workshop the open axilla of a leaf; instead of hairs-a soft fleece easily shorn off-it has for its materials the fierce teeth of the thistle. And these profound changes leave the builder's talents unperturbed; the house is built according to the usual plans.

I agree that I have not allowed for the influence of the centuries. But what would this influence bring about? It is not very clear. The Weevil born in an unusual place retains no trace of the accident that has happened. I extract the adult from his exceptional cell. He does not differ, even in 


\section{The Life of the Weevil}

size, a not very important characteristic, from the Larini born in the regular cell. He has thriven on the axilla of the leaf as he would have done on the thistle-head.

Let us admit that the accident is repeated, that it even becomes a normal condition; let us suppose that the mother decides to abandon her blue balls and to confide her eggs to the axillæ of the leaves indefinitely. What will this change bring about? The answer is obvious.

Since the grub has once developed without hindrance on a site alien to its habits, it will continue to thrive there from generation to generation; with its intestinal cement it will continue to shape a protective pitcher of the same pattern as the old, but, for want of materials, lacking the thatch of withered florets; in short, its talents will remain what they were in the beginning.

This example tells us that the insect, as long as it can accommodate itself to the novel conditions imposed upon it, works in its accustomed fashion; if it cannot do so, it dies rather than change its methods. 


\section{CHAPTER III}

THE BEAR LARINUS

TALLY forth in the night, with a lantern, to spy out the land. Around me, a circle of faint light enables me to recognize the broad masses fairly well, but leaves the fine details unperceived. At a few paces' distance, the modest illumination disperses, dies away. Farther off still, everything is pitchdark. The lantern shows me-and but very indistinctly-just one of the innumerable pieces that compose the mosaic of the ground.

To see some more of them, I move on. Each time there is the same narrow circle, of doubtful visibility. By what laws are these points, inspected one by one, correlated in the general picture? The candle-end cannot tell me; I should need the light of the sun.

Science too proceeds by lantern-flashes; it explores nature's inexhaustible mosaic piece by piece. Too often the wick lacks oil; the 


\section{The Life of the Weevil}

glass panes of the lantern may not be clean. No matter: his work is not in vain who first recognizes and shows to others one speck of the vast unknown.

However far our ray of light may penetrate, the illuminated circle is checked on every side by the barrier of the darkness. Hemmed in by the unfathomable depths of the unknown, let us be satisfied if it be vouchsafed to us to enlarge by a span the narrow domain of the known. Seekers, all of us, tormented by the desire for knowledge, let us move our lantern from point to point: with the particles explored we shall perhaps be able to piece together a fragment of the picture.

To-day the shifting of the lantern's rays leads us to the Bear Larinus (L. ursus, FABR.), the exploiter of the carline thistles. We must not let this inappropriate name of Bear give us an unfavourable notion of the insect. It is due to the whim of a nomenclator who, having exhausted his vocabulary, baffled by the never-ending stream of things already named, uses the first word that comes to hand.

Others, more happily inspired, perceiving 


\section{The Bear Larinus}

a vague resemblance between the sacerdotal ornament, the stole, and the white bands that run down the Weevil's back, have proposed the name of Stoled Larinus ( $L$. stolatus, GMel.). This term would please me; it gives a very good picture of the insect. The Bear, making nonsense, has prevailed. So be it: non nobis tantas componere lites.

The domain of this : Weevil is the corymbed carlina ( $C$. corymbosa, LiN.), a slender thistle, not devoid of elegance, harshlooking though it be. Its heads, with their tough, yellow-varnished spokes, expand into a fleshy mass, a genuine heart, like an artichoke's, which is defended by a hedge of savage folioles broadly welded at the base. It is at the centre of this palatable heart that the larva is established, always singly.

Each has its exclusive demesne, its inviolable ration. When an egg, a single egg, has been entrusted to the mass of florets, the mother moves on, to continue elsewhere; and, should some new-comer by mistake take possession if it, her grub, arriving too late and finding the place occupied, will die.

This isolation tells us how the larva feeds. 


\section{The Life of the Weevil}

The carlina's foster-child cannot live on a clear broth, as does the echinops'; for, if the drops trickling from a wound were sufficient, there would be victuals for several here. The blue thistle feeds three or four boarders without any loss of solid material beyond that resulting from a slight gash. Given such coy-toothed feeders, the heart of the carline thistle would support quite as many.

It is always, on the contrary, the portion of one alone. Thus we already guess that the grub of the Bear Larinus does not confine itself to lapping up discharges of sap and that it likewise feeds upon its artichoke-heart, the standing dish.

The adult also feeds upon it. On the cone covered with imbricated folioles it makes spacious excavations in which the sweet milk of the plant hardens into white beads. But these broken victuals, these cut cakes off which the Weevil has made her meal, are disdained when the egg-laying comes into question, in June and July. A choice is then made of untouched heads, not as yet developed, not yet expanded and 


\section{The Bear Larinus}

still contracted into prickly globules. The interior will be tenderer than after they are full-blown.

The method is the same as that of the Spotted Larinus. With her rostral gimlet the mother bores a hole through the scales, on a level with the base of the florets; then, with the aid of her guiding probe, she installs her opalescent white egg at the bottom of the shaft. A week later, the grub makes its appearance.

Some time in August let us open the thistle-heads. Their contents are very diverse. There are larvæ here of all ages; nymphs covered with reddish ridges, above all on the last segments, twitching violently and spinning round when disturbed; lastly, perfect insects, not yet adorned with their stoles and other ornaments of the final costume. We have before our eyes the means of following the whole development of the Weevil at the same time.

The folioles of the blossom, those stout halberds, are welded together at their base and enclose within their rampart a fleshy mass, with a flat upper surface and cone- 


\section{The Life of the Weevil}

shaped underneath. This is the larder of the Bear Larinus.

From the bottom of its cell the new-born grub dives forthwith into this fleshy mass. It cuts into it deep. Unreservedly, respecting only the walls, it digs itself, in a couple of weeks, a recess shaped like a sugar-loaf and prolonged until it touches the stalk. The canopy of this recess is a dome of florets and hairs forced upwards and held in piace by an adhesive. The artichoke-heart is completely emptied; nothing is respected save the scaly walls.

As its isolation led us to expect, the grub of the Bear Larinus therefore eats solid food. There is, however, nothing to prevent it from adding to this diet the milky exudations of the sap.

This fare, in which solid matter predominates, necessarily involves solid excreta, which are unknown in the inmate of the blue thistle. What does the hermit of the carline thistle do with them, cooped up in a narrow cell from which nothing can be shot outside? It employs them as the other does its viscous drops; it upholsters its cell with them.

I see it curved into a circle with its mouth 58 


\section{The Bear Larinus}

applied to the opposite orifice, carefully collecting the granules as these are evacuated by the intestinal factory. It is precious stuff, this, very precious; and the grub will be careful not to lose a scrap of it, for it has naught else wherewith to plaster its dwelling.

The dropping seized is therefore placed in position at once, spread with the tips of the mandibles and compressed with the forehead and rump. A few waste chips and flakes, a few bits of down are torn from the uncemented ceiling overhead; and the plasterer incorporates them, atom by atom, with the still moist putty.

This gives, as the inmate increases in size, a coat of rough-cast which, smoothed with meticulous care, lines the whole of the cell. Together with the natural wall furnished by the prickly rind of the artichoke, it makes a powerful bastion, far superior, as a defensive system, to the thatched huts of the Spotted Larinus.

The plant, moreover, lends itself to protracted residence. It is slightly built but slow to decay. The winds do not prostrate it in the mire, supported as it is by brush- 


\section{The Life of the Weevil}

wood and sturdy grasses, its habitual environment. When the handsome thistle with the blue spheres has long been mouldering on the edge of the roads, the carlina, with its rot-proof base, still stands erect, dead and brown but not dilapidated. Another excellent quality is this: the scales of its heads contract and make a roof which the rain has difficulty in penetrating.

In such a shelter there is no occasion to fear the dangers which make the Spotted Larinus quit her pitchers at the approach of winter: the dwelling is securely founded and the cell is dry. The Bear Larinus is well aware of these advantages; she is careful not to imitate the other in wintering under the cover of dead leaves and stone-heaps. She does not stir abroad, assured beforehand of the efficiency of her roof.

On the roughest days of the year, in January, if the weather permits me to go out, I open the heads of the carline thistles which I come across. I always find the Larinus there, in all the freshness of her striped costume. She is waiting, benumbed, until the warmth and animation of May return. Then only will she break the dome of her 60 


\section{The Bear Larinus}

cabin and go to take part in the festival of spring.

In majesty of bearing and magnificence of blossom our kitchen-gardens have nothing superior to the cardoon and its near relative the artichoke. Their heads grow to double the size of a man's fist. Outside are spiral series of imbricated scales which, without being aggressive, diverge at maturity in the shape of broad, stiff, pointed blades. Beneath this armament is a fleshy, hemisperical swelling, as big as half an orange.

From this rises a serried mass of long white hairs, a sort of fur, than which a Polar Bear's is no thicker. Closely surrounded by this hair, the seeds are crowned with feathers which double the thickness of the shaggy chevaux de frise. Above this, delighting the eye, blooms the spreading tuft of flowers, coloured a splendid lapis lazuli, like that of the cornflower, the joy of the harvest.

This is the chief domain of a third Larinus (L. scolymi, Oliv.), a big Weevil, thickset, broad-backed, powdered with yellow ochre. The cardoon, which provides our table with the fleshy veins of its leaves, but whose heads are disdained, is the insect's customary home; 


\section{The Life of the Weevil}

but, should the gardener leave the artichoke a few late heads, these are accepted by the Larinus as eagerly as the cardoon's. Under different names, the two plants are merely horticultural varieties; and the Weevil, a thorough expert, makes no mistake about it.

Under the scorching July sun, a cardoonhead exploited by the Larini is a sight worth seeing. Drunk with heat, busily staggering amid the thicket of blue florets, they dive with their tails in the air, sinking and even disappearing into the depths of the shaggy forest.

What do they do down there? It is not possible to observe them directly; but a local inspection after the work is finished will tell us. Between the tufts of hairs, not far from the base, they clear with the rostrum a place to receive their egg. If they are able to reach a seed, they rid it of its feathers and cut a shallow cup in it, an egg-cup as it were. The probe is pushed no farther. The fleshy dome, the tasty heart which one would at first suppose to be the favourite morsel, is never attacked by the pregnant mothers.

As might have been expected, so rich an establishment implies a numerous population. 


\section{The Bear Larinus}

If the head is a good-sized one, it is not unusual to find a score or more of tablecompanions, plump, red-headed grubs, with fat, glossy backs. There is plenty of room for all.

For the rest, they are of a very stay-athome habit. Far from straying at random over the abundant food-supply, in which they might well sample the best and pick their mouthfuls, they remain encamped within the narrow area of the place where they were hatched. Moreover, despite their corpulence, they are extremely frugai, to such a point that, excepting the inhabited patches, the floral head retains its full vigour and ripens its seeds as usual.

In this blazing summer weather, three or four days are enough for the hatching. If the young grub is at some distance from the seeds, it reaches them by slipping along the hairs, a few of which it gathers on its way. If it is born in contact with a seed, it remains in its native cup, for the desired point is attained.

Its food consists, in fact, of the few surrounding seeds, five or six, hardly more; and even so the greater number are only in 


\section{The Life of the Weevil}

part consumed. True, when it has grown stronger, the larva bites deeper and digs in the fleshy receptacle a little pit that will serve as the foundation of its future cell. The waste products of nutrition are pushed backwards, where they set in a hard lump, held in position by the palisade of the hairs.

A modest scale of diet, when all is said: half a dozen unripe seeds and a few mouthfuls taken from the cake consisting of the receptacle. These peaceful creatures must derive singular benefit from their food to acquire such plumpness so cheaply. An undisturbed and temperate diet is better than an uneasy feast.

Two or three weeks devoted to these pleasures of the table and our grub has become a fat baby. Then the blissful consumer becomes a craftsman. The placid gratification of the belly is followed by the worries of the future. We have to build ourselves a castle in which to effect the metamorphosis.

From all around it the grub collects hairs, which it chops into fragments of different lengths. It places them in position with the tip of its mandibles, butts them with its head 


\section{The Bear Larinus}

and presses them by rolling them with its rump. Without further manipulation, this would remain a crazy protection, constantly collapsing and forcing the recluse to make continual repairs. But the builder is thoroughly acquainted with the eccentric ways of its fellow-craftsmen on the echinops; it possesses a cement-factory in the end of its intestine.

If I rear it in a glass tube with a piece of its native artichoke, I see it from time to time curving itself into a ring and gathering with its teeth a drop of a whitish, sticky substance which the hinder part of the grub sparingly provides. The glue is instantly spread hither and thither, swiftly, for it sets quickly. Thus the hairy particles are bound together and what was flimsy felt becomes a solid fabric.

When completed, the work is a sort of turret, the base of which is contained in the little pit of the receptacle, from which the grub obtained part of its nourishment. The dense mane of untouched hairs forms a rampart above and at the sides. It is a somewhat clumsy edifice without, shored up by the adjacent fur; but it is nicely smoothed 


\section{The Life of the Weevil}

within and coated in every part with the intestinal glue, which becomes a lustrous reddish material, like a shellac varnish. The castle-keep measures one and a half centimetres in height. ${ }^{1}$

Towards the end of August most of the recluses are in the perfect state. Many have even burst the vaulted ceiling of their home; rostrum in air, they investigate the weather, awaiting the hour of departure. The cardoon-head by this time is quite dry upon its withered stalk. Let us strip it of its scales and, with a pair of scissors, clip its fur as closely as possible.

The result thus obtained is truly curious. It is a sort of convex brush, pierced here and there with deep cavities wide enough to admit an ordinary lead-pencil. The sides consist of a reddish-brown wall covered with incrustations of hairy debris. Each of these cavities is the cell of an adult Larinus. At first sight one would take the thing for the comb of some extraordinary Wasps'-nest.

Let us mention a fourth member of the same group. This is the Spangled Larinus (L. conspersits, $\mathrm{ScH}$. ), smaller in size than

${ }^{1.585}$ inch.-Translator's Note. 


\section{The Bear Larinus}

the three foregoing species and more simply clad. She is sprinkled with small yellowochre spots on a black ground.

Her most sumptous establishment, as far as I know, is a majestic horror to which the botanists have given the very expressive name of the prickly thistle (Cirsium ferox, D. C.). The moorlands of Provence have nothing in their flora to equal its proud and menacing aspect.

In August this fierce-looking plant raises its voluminous white tufts and with its lofty stature overtops the blue-green clumps of the lavender, that lover of stony wastes. Spread in a rosette on the level of the soil, the root-leaves, slashed into two series of narrow strips, call to mind the backbones of a heap of big fish burnt up by the sun.

These strips are split into two divergent halves, of which one points upwards and the other downwards, as though to threaten the passer-by from every angle. The whole thing, from top to bottom, is a formidable arsenal, a trophy of prickles, of pointed nails, of arrow-heads sharper than needles.

What is the use of this savage panoply? Its discordance with the usual vegetation 


\section{The Life of the Weevil}

accentuates the grace of the plants around it. By striking a harsh and dissonant note, it contributes to the general harmony. The haughty thistle is really superb, standing like a monument amidst the humility of the lavender and thyme.

Others might see in this thicket of halberds a means of defence. But what has the fierce thistle to defend, that it should bristle in this way? Its seed? I doubt, indeed, whether the Goldfinch, the accredited pilferer of the Carduacex, dare set foot on this horrid arsenal. He would be spitted at once.

A humble Weevil will do what the bird dares not undertake and will do it better. She will entrust her eggs to the white tufts; she will destroy the seed of the ferocious plant, which, were it not subjected to a severe thinning, would become an agricultural calamity.

At the beginning of July, I cut off a wellflowered thistle-top; I dip the stem in a bottle full of water and cover my repellent bouquet with a wire-gauze cover, after stocking it with a dozen Weevils. The pairing 


\section{The Bear Larinus}

takes place. Soon the mothers dive down among the flowers and seed-plumes.

A fortnight later, each head is feeding one to four larvæ, already far advanced. Things go fast with the Larini: all must be finished before the thistle-heads wither. September is not over by the time that the insect has assumed the adult form; but there are still laggards at this period, represented by nymphs and even by larvæ.

Built on the same plane as the Artichokeweevil's, the dwelling consists of a sheath having for its base a basin hollowed in the surface of the receptacle. In either case the architecture is the same; so is the method of work. A quilt of hairs, borrowed from the seed-plumes and the mane-like fringe of the receptacle, is heaped around the grub and cemented with the lacquer of the intestine.

Outside this downy bed of wadding is spread a further mattress, a layer of granular excrement. The artist has not thought fit to employ its digestive refuse to greater advantage. It has something better at its disposal. Like the other Larini, it is able to 


\section{The Life of the Weevil}

turn the sordid sewer into a valuable glue- and varnish-factory.

Will this lodging, so softly padded, be its winter home? Not so. In January I inspect the old thistle-heads; in none of them do I find the Weevil. The autumnal population has migrated. For this I see a very good reason.

The thistle, now dead and bare, an ashgrey ruin, is still standing, is still holding out against the north-wind, thanks to its strength and the firmness of its roots; but its flower-heads, emptied by age, are wide open, exposing their contents to the inclemencies of the weather. The fleece of the receptacle is a sponge that swells up with the rain and tenaciously retains the moisture. The same may be said of the cardoon and the artichoke.

In either case, we no longer find the fortress of the carlina, encompassed with convergent folioles; what we see is a spacious, roofless ruin, abandoned to the damp and the cold. The white tuft of the ferocious thistle and the blue tuft of the artichoke are delightful villas in summer; in winter they are uninhabitable residences, sweating mildew. Prudence, the safeguard of the humble, 


\section{The Bear Larinus}

counsels the owners to forestall the final dilapidation and to move. The advice is accepted. At the approach of the rains and frosts, both Larini leave the home of their birth and proceed to take up their winterquarters elsewhere: precisely where I do not know. 


\section{CHAPTER IV}

THE BOTANICAL INSTINCT

MATERnity, when it takes thought 1 for the future, is the most fertile prompter of instinct. To the maternity that prepares board and lodging for the family we owe the wonderful achievements of the Dung-beetles and of the Wasps and Bees. The moment the mother confines herself to laying eggs and becomes a mere germ-factory, the industrial talents disappear as useless.

That bravely-plumed fine lady, the Pine Cockchafer, digs the sandy soil with the tip of her abdomen and buries herself in it laboriously right up to her head. Then a bundle of eggs is laid at the bottom of the excavation; and that is all, once the pit has been filled by means of a casual sweeping.

Constantly ridden by her male during the four weeks of July, the mother Capricorn explores the trunk of the oak at random; she slips her retractible oviscapt, here, there 


\section{The Botanical Instinct}

and everywhere, under the scales of the cracked bark, probing, feeling, choosing the propitious spots. Each time, an egg is laid, almost without protection. This done, she has no further anxiety.

The grub of Cetonia floricola, breaking its shell, some time in August, in the depths of the leaf-mould, goes to feed on the flowers and there idly slumbers; then, an adult Rosechafer, she returns to the heap of rotten leaves, enters it and sows her eggs in the hottest places, those where fermentation rages most fiercely. Let us not ask anything further from her: her talents end with this.

So it is, in the vast majority of cases, with the other insects, weak or powerful, lowly or splendid. They all know where the eggs must be established, but they are profoundly indifferent to what will follow. It is for the grub to muddle through by its own methods. The Pine Cockchafer's larva dives farther into the sand, seeking for tender rootlets softened by incipient decay. The Capricorn's, continuing to drag the shell of its egg behind it, nibbles the uneatable for its first mouthful, making flour of the dead bark and sinking a shaft that leads 


\section{The Life of the Weevil}

it to the wood, on which it feeds for the next three years. The Cetonia's, born in a heap of decomposed vegetable matter, has its food ready to its mouth, without seeking.

With such primitive habits as these, which emancipate the family at birth, without the least previous training, how far removed are we from the maternal tenderness of the Copris, ${ }^{1}$ the Necrophorus, ${ }^{2}$ the Sphex ${ }^{3}$ and so many others! Apart from these privileged tribes, there is nothing very striking to be noted. It is enough to fill with despair the observer in search of facts really worth recording.

The children, it is true, often make up to us for their untalented mothers. Their ingenuity is sometimes amazing, from the time when they are hatched. Witness our Larini. What can the mother do? Nothing but bury the eggs in the blossoms of the thistles. But what a singular industry on the part of the grub which builds itself a thatched hut, upholsters itself a cabin, cards itself a mat-

1 Cf. The Sacred Beetle and Others: chaps. ix., x. and xvi.-Translator's Note.

2 Or Burying-beetle. Cf. The Glow-worm and Other Beetles: chaps. xi. and xii.-Translator's Note.

${ }^{3} \mathrm{Cf}$. The Hunting Wasps: chaps. iv. to x.-Translator's Note. 


\section{The Botanical Instinct}

tress of chopped hairs, makes itself a defensive pitcher, a donjon-keep, with the shellac prepared by its intestine!

When the transformation is accomplished, what perspicacity on the part of the inexperienced insect, when it abandons its cosy home to seek a refuge under the rude shelter of the stones, foreseeing the winter which will ruin the natal villa! We possess the almanac of the past, telling us of the almanac of the future. The insect, with no records of the vicissitudes of the seasons; the insect, born in the dog-days, in the blazing heat of summer: the insect feels instinctively that this period of solar intoxication will not last; it knows, though it has never seen it happen, that its house is doomed soon to collapse; and it makes off before the roof falls in.

For a Weevil, this is fine, magnificent. We might well envy the creature's wisdom in being thus awake to the calamities of the future.

However devoid of industry she may be, the least-gifted mother none the less submits an insoluble problem for our consideration. What is it that leads her to lay her eggs at 


\section{The Life of the Weevil}

spots where the larva will find food to their liking?

The Pieris ${ }^{1}$ goes to the cabbage, in which she has no personal interest. The plant, compressed into a head, has not yet flowered. Besides, its modest yellow blossoms have no greater attraction for the Butterfly than an infinity of other flowers distributed broadcast. The Vanessa ${ }^{2}$ goes to the nettle, on which her caterpillars will feast, but on which the adult insect finds nothing to suck.

When, in the summer gloaming, the Pine Cockchafer has long been whirling in the nuptial ballet around her favourite tree, she refreshes herself after her fatigue by nibbling a few pine-needles; then, with impetuous flight, she goes in search of some bare, sandy tract where the grass-roots lie decaying. Here, as often as not, there is no resinous aroma, there are no more pine-trees, the delight of the plumed beauty; and it is in this place, where nothing appeals to her own

1 The Large White, or Cabbage, Butterfly. Cf. The Life of the Caterpillar: chap. xiv.-Translator's Note.

${ }^{2}$ A genus of very decorative Butterflies, including such well-known species as the Red Admiral, the Painted Lady, the Camberwell Beauty, the Tortoiseshell Butterfly and the Peacock Butterfly.-Translator's Note. 


\section{The Botanical Instinct}

needs, that the mother, half-buried in the ground, will lay her egg.

That ardent lover of roses and hawthornblossom, the Golden Cetonia, leaves the luxury of the flowers, to burrow in the shame of putrescence. She repairs to the compostheap, but is certainly not tempted by any dish to her taste. She cannot sip honey there nor intoxicate herself with perfumed essences. Another reason draws her to this corruption.

At first sight it would seem as if these strange instincts might be explained by the larva's diet, of which the adult would retain a lively recollection. The caterpillar of the Pieris fed on cabbage-leaves; the caterpillar of the Vanessa fed on nettle-leaves; and each of the two Butterflies, endowed with a faithful memory, exploits the plant which has no attraction for her now, but which was a treat for her in her infancy.

In the same way, the Cetonia dives into the heap of leaf-mould because she remembers the feasts of former days, when she was a grub in the midst of the fermenting vegetable matter; and the Pine Cockchafer seeks 


\section{The Life of the Weevil}

the sandy tracts covered with lean tufts of grass, because she remembers her youthful revels underground amid the decaying rootlets.

Such a memory would be almost admissible if the adult's diet were the same as the larva's. We can more or less understand the Dung-bettle, who, herself feeding upon animal droppings, makes them into canned provisions for her family. The diet of maturity and that of infancy are linked as though each were a reminiscence of the other. Uniformity offers a very simple solution of the food-problem.

But what shall we say of the Cetonia passing from the flowers to the sordid refuse of the decayed leaves? Above all, what shall we say of the Hunting Wasps? These fill their own crops with honey and feed their youngsters on prey!

By what inconceivable inspiration does the Cerceris ${ }^{1}$ leave the refreshment-bar of the blossoms, dripping with nectar, to go a-hunting and to slay the Weevil, the game destined for her offspring? How are we to explain

${ }^{1}$ Cf. The Hunting Wasps: chaps i. to iii.-Translator's Note. 


\section{The Botanical Instinct}

the Sphex, who, having refreshed herself at the sugar-works of the field eringo, suddenly flies off, eager to stab the Cricket, the food of her grub?

It is a matter of memory, some will make haste to reply.

Ah no! Please do not speak of memory here; do not appeal to the belly's powers of reminiscence! Man is fairly well endowed with mnemonic aptitudes. Yet which of us has retained the least recollection of his mother's milk? If we had never seen a babe at the breast, we could never suspect that we began life in the same fashion.

This food of earliest infancy is not remembered; it is certified only by example, as by that of the Lamb, which, with bended knees and frisking tail, sucks at the udder and butts it with its head. No, the mouthfuls of mother's milk have left not a trace in the mind.

And you would have it that the insect, after a transformation that has changed it entirely, both inside and out, remembers its first diet, when we ourselves, who are not remoulded in the crucible of a metamorphosis, remain in the most absolute darkness 


\section{The Life of the Weevil}

where ours is concerned! My credulity will not go to that length.

How then does the mother, whose diet is different, distinguish what suits her offspring? I do not know, I never shall know. It is an inviolable secret. The mother herself does not know. What does the stomach know of its masterly chemistry? Nothing. What does the heart know of its wonderful hydraulics? Nothing. The pregnant mother, when establishing her brood, knows no more.

And this unconsciousness provides us with an admirable solution of the difficult problem of victuals. A good example is afforded by the Weevils whom we have just been considering. They will show us with what botanical tact the choice of the food-plant is made.

To entrust the batch of eggs to this or that cluster of florets is not a matter of indifference. It is indispensable that the florets should fulfil certain conditions of flavour, stability, hairiness and other qualities appreciated by the grub. Its selection, therefore, demands a nice botanical discrimination which will recognize off-hand the good and the bad, accept the discovery or reject it. Let us devote a few lines to these 


\section{The Botanical Instinct}

Weevils from the point of view of their botanical attainments.

Scorning variety, the Spotted Larinus is a specialist of immovable convictions. Her domain is the blue ball of the echinops, an exclusive domain, valueless to the others. She alone appreciates it, she alone exploits it; and nothing else suits her.

This particularity, an unchangeable family inheritance, must greatly facilitate her search. When, on the return of the warm weather, the insect leaves her hiding-place, which is doubtless not far from the spot where she was born, she easily finds, on the banks by the road-side, her favourite plant, which is already tipping its branches with pale-blue globes. The dear heritage is recognized without hesitation. She climbs into it, rejoices in her nuptial diversions and waits for the azure balls to mature to the requisite stage. The blue thistle is familiar to her though she sees it for the first time. It was the only one known in the past; it is the only one known in the present. There is no confusion possible.

The second Larinus, the Bear, begins to vary her flora to some extent. I know that 


\section{The Life of the Weevil}

she has two establishments: the corymbed carlina in the plain and the acanthus-leaved carlina on the slopes of Mont Ventoux. ${ }^{1}$

To those who stop at the general aspect and do not have recourse to delicate floral analyses, the two plants have nothing in common. The countryman, clever though he be at distinguishing one plant from a nother, would never think of calling the two by the same generic name. As for the civilized townsman, unless he be a botanist, don't speak of him: his testimony here would be worse than useless.

The corymbed carlina has a tall, slender stem; thin, sparse leaves; a bunch of average flowers, with a receptacle less than half the size of an acorn. The acanthus-leaved carlina spreads, level with the soil, a large, fierce rosette of broad leaves which in shape is not unlike the ornament of a Corinthian capital. There is no stem. In the centre of the leaf-cluster is a flower, one only, but a giant, big as a man's fist.

The people of Mont Ventoux call this magnificent thistle the "mountain artichoke."

1 The nearest mountain to the author's village. Cf. The Hunting Wasps: chap. xi.-Translator's Note. 


\section{The Botanical Instinct}

They gather it and use the base of the flower in making omelettes not devoid of merit; this base is very fleshy, is saturated in milk with a nutty flavour and is delicious even when raw.

Sometimes they use the plant as an hygrometer. Nailed to the lintel of the byre, the carlina closes its flower when the air is moist and opens it in a superb sun of golden scales when the air is dry. With beauty added, it is the inverse equivalent of the celebrated rose of Jericho, an unsightly bundle which expands in wet and shrivels in dry weather. If the rustic hygrometer were a foreigner, it would be famous; being an ordinary product of Mont Ventoux, it is slighted.

The Larinus, for her part, knows it very well, not as a meteorological apparatus, a very useless thing to her for foretelling the weather, but as provender for her family. Many a time, on my excursions in July and August, I have seen the Bear Weevil very busy on the mountain artichoke wide open in the sun. There is no doubt what she was doing there: she was attending to her eggs.

I regret that my then preoccupations, which were concerned with botany, did not 


\section{The Life of the Weevil}

permit me to observe the mother's methods more closely. Does she lay several eggs in this rich morsel? There is enough to satisfy a numerous brood. Or does she lay only one, repeating here what she does on the corymbed carlina, a middling ration? There is nothing to tell us that the insect is not to some extent versed in domestic economy and does not proportion the number of the guests to the abundance of the provisions.

If this point is obscure, another and one of greater interest is quite evident: the Bear Larinus is a clear-sighted botanist. She recognizes as carlina, the family food, two very dissimilar plants, which none of us, unless he were an expert, would have thought of grouping together; she accepts as botanical equivalents the gorgeous rosette, eighteen inches across, whose spokes lie on the ground, and the shabby-looking thistle that stands erect and spare.

The Spangled Larinus extends her domain still farther. Though she has not the fierce thistle with the white heads, she recognizes the good qualities of another vegetable horror, one with pink heads this time. This is the common horse-thistle (Cirsium lanceo- 


\section{The Botanical Instinct}

latum, Scop.). The difference in the colour of the flowers causes her no hesitation.

Can she be apprised by the majestic stature, by the sturdy prickles? No, for we next see her established on a humble and much less savage plant, Carduus nigrescens, VILL., which rises hardly more than nine inches from the ground.

Can it be the size of the heads that regulates her choice? Not so, either, for the paltry heads of Carduus tenuiflorus, CART., are accepted as readily as the sizable blooms of the above three thistles.

But the subtle expert is even cleverer than this. Regardless of mien, foliage, flavour or colour, she actively exploits Kentrophyllum lanatum, D. C., a plant with wretched yellow flowers soiled by the dust of the roads. To recognize a Carduacea in this dry and unsightly plant you have to be a botanist or a Weevil.

A fourth Larinus (L. scolymi, Oliv.) surpasses the Spangled Larinus. We find her at work on the garden artichoke and the garden cardoon, both of them giants that lift their great blue heads to a height of six feet and more. We meet her afterwards on 


\section{The Life of the Weevil}

a niggardly centaury (Centaurea aspera, LIN.), with ragged heads, smaller than the tip of one's little finger, trailing on the ground; we see her founding colonies on the various thistles beloved of the Spangled Larinus, even on Kentrophyllum lanatum. Her botanical knowledge of plants so dissimilar gives us food for reflection.

As a Weevil, she recognizes very clearly, without resorting to tests, what is artichokeheart and what is not, what suits her offspring and what would harm it; and I, as a naturalist, versed by assiduous practice in the flora of my district, would not dare, without prudent enquiries, to bite into this or that fruit or berry were I suddenly transported to another country.

She is born with her knowledge; and I have to learn. Every summer, with superb audacity, she goes from her thistle to various others which, having no similarity of appearance, ought, one would think, to be rejected as suspicious hostelries. On the contrary, she accepts them, recognizes them as her own; and her confidence is never betrayed.

Her guide is instinct, which instructs her unerringly, within a very restricted circle; 86 


\section{The Botanical Instinct}

mine is intelligence, which gropes, seeks, goes astray, finds its way again and ends by soaring with an incomparable flight. The Larinus knows the flora of the thistles without having learnt it; man knows the flora of the world after long study. The domain of in. stinct is a speck; that of intelligence is the universe. 


\section{CHAPTER V}

THE ELEPHANT WEEVIL

SOME of our machines have odd-looking parts which seem inexplicable so long as they are seen in repose. But wait until the whole is set in motion, when the uncouth contrivance, with its gear-wheels biting and its jointed rods opening and closing, will reveal an ingenious combination wherein everything is cunningly arranged in view of the effects to be obtained. It is the same with various Weevils, notably the Balanini, ${ }^{1}$ who, as their name tells us, are charged with the exploitation of acorns, nuts and other, similar fruits.

The most remarkable in my part of the country is the Elephant Weevil, or Acornweevil (Balaninus elephas, ScH.). What a well-named insect! Its title is a picture in itself. It is a living caricature, with its prodigious pipe-stem, no thicker than a horse-

1 From the Latin balanus, an acorn.-Translator's Note. 


\section{The Elephant Weevil}

hair, reddish, almost straight and so long that the insect is obliged to carry it extended like a lance at rest, lest it should stumble, hampered by its instrument. What does it do with this enormous pike, with this ridiculous nose?

Here I see some shrugging their shoulders. In fact, if the sole object of life is to make money by hook or by crook, such queries are sheer madness. Happily there are others to whom nothing in the majestic problem of things is trivial. They know of what humble dough the bread of thought is kneaded, a bread no less necessary than that made from wheat; they know that husbandmen and enquirers alike feed the world with an accumulation of minute fragments.

Let us take pity on the question and proceed. Without seeing it at work, we already suspect the Weevil's paradoxical beak of being a drill similar to those which we employ to bore through the hardest substances. Two diamond-points, the mandibles, form its terminal bit. Like the Larini, but under conditions of greater difficulty, the Weevil must use it to prepare the way for installing the egg. 


\section{The Life of the Weevil}

But suspicion, however well-founded, is not certainty. I shall not know the secret unless and until I witness the performance.

Chance, the servant of those who solicit her patiently, procures me a meeting with the Acorn-weevil at work in the first fortnight of October. My surprise is great, for at this late period all industrial activity as a rule is at an end. The entomological season closes with the first touch of cold.

It happens to be wild weather to-day; an icy north-wind is roaring, chapping one's lips. One needs a stout faith to go out on a day like this to inspect the thickets. Yet, if the Weevil with the long churchwarden exploits the acorns, as I imagine that she does, now or never is the time to look into things. The acorns, still green, have attained their full dimensions. In two or three weeks they will possess the deep brown of perfect maturity, soon to be followed by their fall.

My hare-brained excursion gives me a success. On the ilexes I surprise a Weevil, with her proboscis half-sunk in an acorn. To observe her with due care is impossible 


\section{The Elephant Weevil}

while the branches are being lashed and shaken by the mistral. I break off the twig and lay it gently on the ground. The insect takes no notice of its removal and goes on with its job. I squat down beside it, sheltered from the gale behind a clump of brushwood, and watch operations.

Shod with clinging sandals which will enable her later, in my cages, to scale a perpendicular pane of glass, the Weevil is firmly fixed on the smooth and sloping curve of the acorn. She is working her drill. Slowly and awkwardly she moves around her implanted rod, describes a semicircle whose centre is the perforated point and then, retracing her steps, describes the semicircle in the reverse direction. And this is repeated several times over. We do the same when, by an alternating movement of the wrist, we make a hole in a piece of wood with a bradawl.

Little by little, the rostrum enters. In an hour's time, it has disappeared entirely. A brief rest follows. Then at last the instrument is withdrawn. What will happen next? Nothing more, this time. The 


\section{The Life of the Weevil}

Weevil abandons her shaft and solemnly retires, hiding among the dead leaves. I shall learn no more to-day.

But I have been given a hint. On still days, more favourable to my hunting, I return to the spot and soon have the wherewithal to stock my cages. Foreseeing serious difficulties because of the slowness of the work, I prefer to continue my studies indoors, with the unlimited leisure to be found at home.

This was an excellent precaution. If I had tried to go on as I had begun and to observe the Weevil's actions in the freedom of the woods, never should I have had the patience to follow to the end the choice of the acorn, the boring of the hole and the laying of the eggs-even presuming that my discoveries were propitious-so meticulously deliberate is the insect in its business, as the reader will presently be able to judge.

The copses frequented by my Weevil are composed of three kinds of oaks: the ilex and the durmast, which would become fine trees if the woodcutter gave them time, and lastly the kermes-oak, a wretched, scrubby bush. The first, the most plentiful of the three, 


\section{The Elephant Weevil}

is the Weevil's favourite. Its acorns are firm, long in shape and moderate in size; the cup is covered with little warts. Those of the durmast oak are generally stunted, short, wrinkled and subject to premature falls. The dryness of the Sérignan hills does not suit them. The Weevil therefore accepts them only in the absence of something better.

The humility of the kermes, a dwarf shrub, a truly comic oak, which a man can step over at a stride, is contrasted by the wealth of its acorns, which are large, swelling ovoids, set in a cup bristling with sharp scales. The Weevil could not have a better home. It forms a strong dwelling and a copious storehouse.

I place a few sprigs from these three oaks, well-furnished with acorns, under the dome of my wire-gauze covers, with their ends dipped in a tumbler of water to keep them fresh; I install a suitable number of couples; lastly, I stand the cages on the window-sills of my study, where they get the direct sunlight for the greater part of the day. Let us now possess our souls in patience and keep a constant watch. We shall be rewarded. The exploitation of the acorn is worth seeing. 


\section{The Life of the Weevil}

Things do not drag on so very long. Two days after these preparations, I arrive at the exact moment when the work begins. The mother, larger than the male and supplied with a longer drill, is inspecting her acorn, no doubt in view of the eggs.

She goes over it step by step, from tip to stem, above and below. Walking is easy on the wrinkled cup; it would be impracticable on the rest of the surface if the soles of her feet were not shod with clinging pattens, with brushes which enable her to keep her balance in any position. Without tripping or stumbling, therefore, the insect walks with equal ease, over the top or bottom or up the sides of her slippery pedestal.

The choice is made; the acorn is recognized as being of good quality. The time has come to sink the hole. The rod is difficult to wield, because of its excessive length. To obtain the best mechanical effect, the instrument must be held at right angles to the convex surface; and the cumbrous tool which, out of working-hours, projects in front of the worker must now be brought under her.

To achieve this object, the Weevil raises 


\section{The Elephant Weevil}

herself on her hind-legs and stands on the tripod formed by the tip of the wing-cases and of the hinder tarsi. Nothing could be droller than this strange well-sinker, standing erect and drawing her nasal rapier towards her.

The trick is done: the drill is now held plumb. The boring begins. The method is that which I saw employed in the woods, on the day when the wind was so strong. Very slowly, the insect veers from right to left and from left to right alternately. Her tool is not a gimlet, a spiral, corkscrew. like implement which enters as the result of a rotary movement always in one direction; it is a trocar which progresses by successive bites, by eating away now in one direction, now in another.

Before continuing, let me give room to an accidental fact, which is too striking to be passed over. On various occasions I have found the insect dead at its work. The deceased occupies a strange position, which would give food for laughter if death were not always a serious event, especially when it comes suddenly, in the midst of toil. The boring-tool is implanted in the acorn merely 


\section{The Life of the Weevil}

by its tip: the work was just beginning. At the top of the rod, a lethal stake, the Weevil is suspended in mid-air, at right angles, far from the supporting surface. She is driedup, dead since I know not how many days. The legs are stiff and contracted under the abdomen. Even if they retained the flexibility and the power of extension which was theirs in life, they would not be able, by a long way, to reach the support of the acorn. What has happened then, that the poor wretch should be impaled like an insect in our collections with a pin stuck through its head?

What has happened is a workshopaccident. Because of the length of her bradawl, the Weevil begins by working upright, standing on her hind-legs. Imagine a slip, a false move of the two clinging grapnels; and the unskilful Weevil will instantly lose her footing, dragged away by the elasticity of the probe, which she must have forced slightly and bent at the start. Thus lifted to some distance from her foothold, she vainly struggles, hanging in the air; nowhere can her tarsi, those safety anchors, find anything to grip. She succumbs exhausted at 96 


\section{The Elephant Weevil}

the top of her stake, for lack of a support whereby to release herself. Like the workmen in our factories, the Elephant Weevil also is sometimes the victim of her machinery. Let us wish her good luck and sure feet, careful not to slip, and continue.

This time the mechanism works perfectly, but so slowly that the descent of the drill, even when magnified by the lens, cannot be perceived. And the insect veers and veers about, rests and again resumes her work. An hour, two hours pass, of enervating, sustained attention, for I want to see the action at the exact moment when the Weevil withdraws her probe, turns round and deposits her egg at the mouth of the well. This at least is how I foresee events.

Two hours elapse, exhausting my patience. I make arrangements with my household. Three of us will relieve one another in turn, keeping an uninterrupted watch on the obstinate creature, whose secret I must have at all costs.

I was well-advised to call in helpers to lend me their eyes and their attention. After eight hours, eight endless hours, the sentry on the watrh summons me. The 


\section{The Life of the Weevil}

insect appears to have finished. It does in fact step back, it withdraws its drill, carefully, lest it should bend it. The tool is now outside, once more pointing forwards, in a straight line.

This is the moment. .. Alas, no! Once again I am cheated: my eight hours' watch has led to nothing. The Weevil decamps, abandons the acorn without making use of her boring. Yes, I was certainly right to distrust observation in the woods. Such a period of waiting among the ilexes, under the scorching sun, would have been an unbearable torture.

All through October, with the aid of helpers when needful, I remark numerous borings not followed by any laying. The operation varies greatly in length. Generally it lasts a couple of hours; sometimes it takes half the day or even more.

What is the object of these shafts, made at such cost of time and labour and very often left unstocked? Let us first look for the site occupied by the egg and forming the grub's earliest mouthfuls; then perhaps the reply will come.

The inhabited acorns remain on the oak, 98 


\section{The Elephant Weevil}

encased in their cups as though nothing abnormal were happening to injure the seedlobes. They are easily recognized with a little attention. Not far from the cup, on the smooth and still green shells, a little speck shows, just like the prick of a fine needle. Soon it is surrounded by a narrow brown ring, the result of mortification. This is the mouth of the hole. At other times, but less often, the opening is made through the cup itself.

We will take the acorns recently perforated, that is to say, those with a pale puncture, not yet surrounded by the brown ring which will appear in time. Shell them. Several contain no foreign matter: the Weevil has bored them without laying her eggs in them. These represent the acorns worked for hours and hours in my cages and not afterwards used. Many contain an egg.

Now, however far above the cup the entrance to the pit may be, this egg is always right at the bottom, at the base of the seedlobes. There is here, provided by the cup, a soft, blanket-like layer which imbibes the sapid exudations from the tip of the peduncle, the source of nourishment. I see 


\section{The Life of the Weevil}

a young grub, hatched before my eyes, nibble as its first mouthfuls this tender woolly mass, this moist cake flavoured with tannin.

This dainty, juicy and easy of digestion, like all nascent organic matter, is found only at this particular spot; and it is solely here, between the cup and the base of the seedlobes, that the Weevil lodges her egg. The insect knows to a nicety the position of the morsels best-suited to the feeble stomach of the new-born larva.

Above this is the comparatively coarse bread of the seed-lobes. Refreshed by its first meal at the drinking-bar, the grub enters it, not directly, but through the tunnel opened by the mother's probe, a tunnel littered with crumbs, with half-masticated fragments. This light farinaceous food, prepared in a column of appropriate height, gives strength; and the grub next penetrates right into the firm substance of the acorn.

These facts explain the egg-layer's tactics. What is her object when, before proceeding to bore the hole, she inspects her acorn, above, below, in front and behind, with fastidious care? She is making sure that the 


\section{The Elephant Weevil}

fruit is not already occupied. It is a rich larder, certainly; nevertheless, there is not enough for two. Never indeed have I found two larvæ in the same acorn. One only, always one only, digests the generous morsel and converts it into pale-green flour before leaving it and descending to the ground. Of the seed-lobe bread, at most an insignificant crumb remains. The rule is that each grub has its loaf, each consumer its ration consisting of one acorn.

Before trusting the egg to the acorn, therefore, it is important to examine it, to ascertain if it already has an occupant. Now this occupant, if any, is at the bottom of a crypt, at the base of the acorn, under the cover of a cup bristling with scales. Nothing could be more secret than this hiding-place. No eye would suspect the presence of a recluse if the surface of the acorn did not bear the mark of a tiny puncture.

This just visible mark is my guide. Its appearance tells me that the fruit is inhabited or that it has at least been prepared for the reception of the egg; its absence assures me 


\section{The Life of the Weevil}

that the acorn has not been appropriated. The Weevil, beyond a doubt, obtains her information in the same manner.

I see things from a height, with a comprehensive glance, assisted if need be by the magnifying-glass. I turn the object for a moment in my fingers; and my inspection is over. The Weevil, investigating at close quarters, is obliged to point her microscope more or less everywhere before detecting the tell-tale speck with certainty. Moreover, the welfare of her family compels her to make a far more scrupulous search than that prompted by my curiosity. This is why her examination of the acorn is so excessively protracted.

It is done: the acorn is accepted as a good one. The drill is driven in and kept working for hours; then, very often, the insect goes away, despising her work. The laying of the egg does not follow on the boring. What is the object of so great and so long an effort? Can the Weevil simply be piercing the fruit to satisfy her appetite and obtain refreshment? Can the reed-like beak go down to the depths of the barrel to draw, from the likeliest spots, a few mouthfuls of 


\section{The Elephant Weevil}

sustaining drink? Can the enterprise be a matter of personal nourishment?

I thought so at first, though I was a little surprised at this display of perseverance in view of a sip. The males taught me to abandon the idea. They too possess a long rostrum, capable of opening a well if necessary; nevertheless I never see one standing on an acorn and working at it with his drill. Why take so much trouble? A mere nothing satisfies these frugal eaters. A superficial digging with the tip of the proboscis into the tender leaf yields enough to maintain their strength.

If they, the idlers who have leisure to enjoy the delights of the table, want no more, how will it be with the mothers, busy with the laying? Have they the time to eat and drink? No, the pierced acorn is not a bar at which to lounge, sipping without end. That the beak, when driven into the fruit, levies a small mouthful is possible; but this scrap is certainly not the object in view.

I seem to catch a glimpse of the real object. The egg, as we said, is always at the base of the acorn, in the midst of a sort of wadding moistened by the sap that oozes 


\section{The Life of the Weevil}

from the stalk. At the hatching, the grub, incapable as yet of tackling the firm substance of the seed-lobes, chews the delicate felt at the bottom of the cup and feeds upon its juices.

But, as the fruit matures, this cake becomes more solid and changes in flavour and in the consistency of its pulp. What was soft hardens, what was moist dries up. There is a period during which the conditions necessary to the new-born grub's welfare are fulfilled to perfection. At an earlier stage, things would not have reached the requisite degree of preparation; later, they would be too ripe.

Outside, on the green rind of the acorn, there is nothing to show the progress of this inner cooking. In order not to serve her grub with noxious food, the mother, inadequately informed by the sight of the acorn, is therefore obliged first to taste with the tip of her proboscis what lies at the bottom of the store-room.

The nurse, before giving baby his spoonful of pap, puts her lips to it to try it. The mother Weevil in the same way, with no less affection, dips her probe to the bottom I04 


\section{The Elephant Weevil}

of the basin, to try its contents before bequeathing them to her son. If the food is considered satisfactory, the egg is laid; if not, the boring is abandoned without more ado. This explains the perforations of which no advantage is taken after much laborious work. The soft bread at the bottom, carefully tested, was not found to be in the required condition. How particular, how fastidious are these Weevils, where the first mouthful of the family is concerned!

To place the egg in a spot where the newborn grub will find light, juicy, easily-digested food is not enough for these far-seeing mothers. Their care goes farther. An intermediate diet would be useful, to lead the little larva from the dainty fare of the first hours to the regimen of hard bread. This intermediate diet is in the gallery, the work of the mother's beak. Here are crumbs, particles bitten off by the shears of the proboscis. Moreover, the sides of the tunnel, softened by mortification, are better. suited than the rest to the feeble mandibles of the novice.

Before nibbling at the seed-lobes, the grub does in fact embark upon this tunnel. It 


\section{The Life of the Weevil}

feeds on the meal found along the road; it gathers the discoloured atoms hanging from the walls; and lastly, when strong enough, it attacks the loaf of the kernel, digs into it and disappears inside. The stomach is ready. The rest is a blissful feast.

This tubular nursery must be of a certain length to satisfy the needs of infancy; and so the mother works her drill accordingly. If the thrust of the probe were intended solely for sampling the material at the base of the acorn and examining its degree of maturity, the operation would be much shorter, since it could be started near that base, through the cup. This advantage is not unrecognized: I have happened to surprise the insect working upon the scaly cupule.

I see in this merely an attempt of the hurried mother to obtain information. If the acorn suits, the boring will be made over again, higher up, outside the cup. When the egg is to be laid, the rule, in fact, is to bore through the acorn itself, as high up as the length of the tool permits.

What is the object of this long boring, which is not always finished in half a day? 


\section{The Elephant Weevil}

What is the use of this stubborn perseverance when, near the stalk, at the cost of much less time and labour, the bradawl would reach the desired point, the running spring whereat the nascent grub is to slake its thirst? The mother has her reasons for going to all this trouble: by so doing she reaches the regular spot, the base of the acorn, and by this very action-a most valuable result-prepares a long tube of meal for her son.

These are all trivialities! Not so, if you please: matters of great importance rather, telling us of the infinite cares that preside over the preservation of the least of things and bearing witness to a higher logic which regulates the smallest details.

The Weevil, so happily inspired as a breeder, has her place in the world and is worthy of consideration. So at least thinks the Blackbird, who gladly makes a meal of the long-beaked insect when the berries begin to run short at the end of autumn. It is a small mouthful but a tasty one; and it makes a pleasant change after the bitterness of the olive that still resists the cold.

And what were the reawakening of the woods in spring, without the Blackbird and 


\section{The Life of the Weevil}

his rivals! Were man to disappear, annihilated by his own follies, the springtide festival would be no less solemnly celebrated by the Blackbird's triumphant fluting.

To the most deserving part played in feasting the bird, the minstrel of the forests, the Weevil adds another, that of moderating the amount of vegetable lumber. Like all the mighty really worthy of their power, the oak is generous: it yields acorns by the bushel. What could the earth do with this abundance? The forest itself would be stifled for lack of space; excess would ruin the essential.

But, as soon as victuals are plentiful, there comes from every side a rush of consumers only too eager to reduce the headlong production. The Field-mouse, a native, hoards acorns in a stone-heap, near her hay mattress. A stranger, the Jay, arrives from a distance, in flocks, apprised I know not how. For some weeks he flies feasting from oak to oak, giving vent to his joys and his emotions by screeching like a strangled Cat; then, having fulfilled his mission, he goes back to the north whence he came.

The Weevil has been beforehand with I08 


\section{The Elephant Weevil}

them all. She confided her eggs to the acorns while these were still green. They are now lying on the ground, brown before their time and pierced with a round hole through which the larva has escaped after consuming the contents. It would be easy under a single oak to fill a basket with these empty ruins. The Weevil has done more than the Jay and more than the Field-mouse to get rid of the superfluity.

Soon man arrives, thinking of his Pigs. In my village it is a great event when the public crier announces the opening day for gathering acorns in the common woods. The more zealous inspect the ground on the eve, in order to select a good place. Next morning, at peep of day, the whole family is there. The father beats the higher branches with a pole; the mother, wearing a large canvas apron which allows her to force her way through the thickets, gathers from the tree all that her hand can reach; the children pick up what lies on the ground. And the baskets are filled, followed by the hampers and the sacks.

After the glee of the Field-mouse, the Jay, the Weevil and so many others, here 


\section{The Life of the Weevil}

comes that of man, calculating how much bacon his harvest will bring him. One regret mingles with the rejoicings, that is to see so many acorns scattered on the ground, pierced, spoilt, good for nothing. Man inveighs against the author of the damage. To listen to him, you would think that the forest were his alone and that the oaks bore fruit only for his Pig.

"My friend," I would say to him, "the forest-ranger can't summon the delinquent and this is just as well, for our self-seeking, which is inclined to look upon the acorn-crop only in the light of a string of sausages, would lead to tiresome results. The oak invites the whole world to enjoy its fruits. We take the biggest share, because we are the strongest. That is only our right. . . . But what ranks ever so much higher is a fair division among the various consumers, great and small, all of whom play their part in this world. If it is well that the Blackbird should whistle and gladden the burgeoning of the spring, then let us not take it ill that the acorns are rotten. For here the Blackbird's dessert is prepared, the Weevil, 


\section{The Elephant Weevil}

a dainty mouthful that lends fat to his rump and music to his throat."

Let us leave the Blackbird to sing and hark back to the Weevil's egg. We know where it is: at the base of the acorn, in the tenderest and juiciest part of the fruit. How did it get there, so far from the entrance, which is situated above the edge of the cup. A very small question, it is true, even puerile, if you will. Let us not despise it: science is built up of puerilities.

The first man to rub a piece of amber on his sleeve and thereupon to discover that the piece aforesaid attracted bits of straw certainly did not suspect the electric wonders of our day. He was amusing himself in his artless fashion. When repeated and tested in every conceivable manner, this child's plaything became one of the forces of the world.

The observer must neglect nothing: he never knows what the humblest fact may bring forth. I therefore repeat the question: by what means was the Weevil's egg placed so far from the entrance?

To any one who was not yet aware of the position of the egg, but who knew that the 


\section{The Life of the Weevil}

grub attacks the base of the acorn first, the reply would appear to be as follows: the egg is laid at the entrance of the tunnel, on the surface; and the grub, crawling along the gallery dug by the mother, of its own accord reaches the point where its infant'sfood exists.

At first, before I possessed adequate particulars, this explanation was also my own; but the mistake was soon dispelled. I pluck the acorn when the mother withdraws after for an instant applying the tip of her abdomen to the orifice of the tunnel which her rostrum has just bored. The egg, so it seems, must be there, at the entrance, close to the surface. . . But not at all: it is no: there; it is at the other end of the passage! If I dared to take the liberty, I should say that it has gone down it as a stone falls to the bottom of a well.

We must hasten to abandon this silly notion: the tunnel is infinitely narrow and blocked with shavings, so that any such descent would be impossible. Besides, according to the direction of the stalk, which may be either downwards or upwards, a fall 


\section{The Elephant Weevil}

in one acorn would mean an ascent in another.

A second, no less risky explanation suggests itself. You say to yourself:

"The Cuckoo lays her egg in the grass, anywhere; she picks it up in her beak and goes and places it as it is in the Warbler's narrow nest."

Can the Weevil adopt a similar method? Can she use her rostrum to push her egg to the base of the acorn? I cannot see that the insect has any other implement capable of reaching this remote hiding-place.

And yet we must hastily reject this quaint explanation as a despairing resource. Never does the Weevil lay her egg in the open and then take it in her beak. If she did, the delicate germ would infallibly perish, destroyed in the attempt to push it down a narrow, half-choked passage.

My perplexity is great; and it will be shared by any of my readers who are acquainted with the Weevil's structure. The Grasshopper owns a sabre, a laying-tool which sinks into the ground and sows the eggs at the requisite depth; ${ }^{1}$ the Leucospis is 


\section{The Life of the Weevil}

endowed with a probe which makes its way through the Chalicodoma's ${ }^{2}$ masonry and slips the egg into the cocoon of the fat, sleepy larva; but this Weevil of ours has none of these rapiers, daggers or larding-pins; she has nothing at the tip of her abdomen, absolutely nothing. And yet she has but to apply that tip to the narrow opening of the well for the egg to be lodged, forthwith, at the very bottom.

Anatomy will supply the key to the riddle, which is otherwise undecipherable. I open the mother's abdomen. What meets my eyes astounds me. There is here, occupying the whole length of the body, an extraordinary piece of mechanism, a stiff, red, horny rod, I was almost saying a rostrum, so closely does it resemble that of the head. It is a tube, slender as a horse-hair, widening slightly like a blunderbuss at the free end and swollen like an egg-shaped capsule at the base.

This is the laying-tool, equalling the brad-

${ }^{1}$ The Life of the Grasshopper: chap. xiv.-Translator's Note.

2 The Mason-bee. Cf. The Mason-bees: passim.Translator's Note. 


\section{The Elephant Weevil}

awl in length. As far as the perforating beak reaches, so far can the egg-probe reach, that inner beak. When working upon her acorn, the Weevil chooses the point of attack so that the two complementary instruments can both reach the desired point, the base of the fruit.

The rest now stands self-explained. When the work of drilling is finished and the gallery ready, the mother turns round and places the tip of her abdomen over the entrance. She unsheathes and protrudes her internal mechanism, which readily sinks through the loose shavings. No sign appears of the directing probe, so quickly and discreetly does it work; no sign appears either when, after the egg has been placed in position, the instrument goes up again and gradually slips back into the abdomen. It is over; the mother departs and we have seen none of her little secrets.

Was I not right to persist? An apparently insignificant fact has told me definitely what the Larini had already led me to suspect. The long-beaked Weevils have an inner probe, an abdominal rostrum, which 


\section{The Life of the Weevil}

no outward sign betrays; they possess, hidden away in their belly, the counterpart of the Grasshopper's sabre and of the Ichneumonfly's larding-pin. 


\section{CHAPTER VI}

THE NUT-WEEVIL

IF a peaceful home, a good stomach and a secure livelihood are enough to bring happiness, then the Nut-Weevil is truly a happy creature, more so even than the famous Rat who retired into a Dutch cheese. The hermit of the fabulist ${ }^{1}$ had kept up certain relations with the world, the source of all his troubles. One day, a deputation from the Rat folk came to ask him for a trifling alms. The recluse listened to their complaints with an unwilling ear; he told them that he could not help them, promised to pray for them and shut the door without further ado.

Hard though he was upon the needs of others, this visit of famished beggars must have disturbed his digestion somewhat: history does not tell us so, but we are at liberty to believe it. The hermit of the

1 Jean de La Fontaine (1621-1695).-Translator's Note. II 7 


\section{The Life of the Weevil}

naturalist is not subject to these annoyances. Its dwelling is an inviolable cell, a coffer made all in one piece, with neither door nor wicket for distressed bores to come knocking at. Within is absolute quiet, nothing enters of the sounds or cares of the outer world. An excellent lodging, neither too hot nor too cold, peaceful and closed to all. An excellent table, besides, and a sumptuous. What more could any one ask for? The smug inmate waxes big and fat.

We all know the rascal. Which of us, when a boy, cracking a hazel-nut with his strong teeth, has not bitten into something acrid and sticky? Ugh! It's the nutmaggot! Let us conquer our repugnance and examine the creature closely. It is worth the trouble.

We see a plump and lusty grub, bent into a bow, legless and milk-white, except the head, which is capped with yellowish horn. When taken from its cell and laid on the table, the thing wriggles about, coiling and uncoiling and fidgetting without contriving to shift its place. It is denied the power of locomotion. What would the worm do with that power, boxed up as it is? For that matter, this is II 8 


\section{The Nut-Weevil}

a feature common to the Weevil tribe, all of whom are inveterate stay-at-homes in their larval stage. Such is the hermit whose history follows below, the anchorite with the sleek and rounded rump, the larva of the Nut-weevil (Balaninus nucum, LiN.).

The kernel of the hazel-nut is its cake, an abundant provision, which it never or but very seldom finishes entirely, so greatly do the victuals exceed the utmost requirements of obesity. There is plenty to enable one alone to live comfortably for three or four weeks; but it would mean short commons for two. And so the victuals are scrupulously rationed: to each nut its grub, no more.

I have happened on very rare occasions to find two. The late-comer, the offspring of some ill-informed mother, had seated itself at table beside the other, without much profit to itself. There was not much left of the cake; moreover, the still feeble intruder seemed to have had a bad reception from the powerful and jealous owner of the property. There was no doubt about it: the superfluous weakling was doomed to perish. The Weevil knows no more of mutual aid among kinsmen than the Rat in the cheese. 


\section{The Life of the Weevil}

Each for himself: such is the savage and bestial law, even in a nutshell.

The dwelling is a perfectly continuous fortification, without a joint or fissure for an invader to slip through. The walnut-tree forms the shell of its fruit out of two halves joined together, with a line of least resistance left between them; the hazel makes its kegs with a single stave, curved into an arch that is equally strong at all points. How did the grub of the Balaninus obtain access to this fortress?

On the surface, smooth as polished marble, the eye perceives nothing to explain the entrance of an exploiter from without. One can picture the surprise and the artless imaginings of those who first remarked the peculiar contents of the intact nut, without any sort of opening to it. The plump maggot, living inside it, could not be an alien. It was therefore born of the fruit itself, under the influence of an unlucky moon. It was a child of putrefaction hatched by a mist.

A faithful custodian of the ancient beliefs, the peasant of to-day always attributes maggoty nuts and other fruits spoiled by insects to the moon and a passing miasma. And 


\section{The Nut-Weevil}

this will be so indefinitely, until our country schools yield the place of honour to cheerful, invigorating studies in the fields.

Let us replace these inanities by the reality. The grub is certainly an outsider, an invader; and, if it has made its way in, this is because it has found a passage somewhere. Let us look for this passage, which escaped us at the first examination, with the aid of a magnifying-glass.

The search does not take long. The base of the nut displays a wide, rough, lightcoloured depression, to which the cup was fastened. On the confines of this area, a little way outside it, is a darker speck. This is the entrance to the stronghold; this is the key to the riddle.

The rest follows without further enquiry and is very clearly interpreted by the data provided by the Elephant Weevil. The Nut-weevil also bears a buccal drill, still inordinately long, but this time slightly curved.

I can well imagine the insect, like its relative of the acorns, standing erect on the tripod formed by the tip of its wing-covers and the hinder tarsi; it assumes a posture worthy of portrayal by a fantastic pencil; it 


\section{The Life of the Weevil}

plants its instrument perpendicularly; it patiently veers and veers again.

The work is arduous, very arduous, for the nut is selected when nearly ripe, to provide the grub with more savoury and more abundant food; it is thick and tough, much more so than the rind of an acorn. If the Acorn-weevil takes half a day to bore her passage, how long must the Nut-weevil's task be, how patient her persistence! Perhaps her rod is specially hardened. We can temper our drills till they wear away granite; no doubt the Weevil, in the same way, provides her boring-tool with a bit of triple hardness.

Quickly or slowly, the augur sinks into the base of the nut, where the tissues are softer and milkier; it enters obliquely, making a fairly long journey, to prepare for the grub a column of semolina suited to its first needs. Whether boring into nuts or into acorns, the Balanini make the same delicate preparations for the benefit of their offspring.

At length there comes the placing of the egg, right at the bottom of the shaft. Here the strange method which we already know is repeated. With a hinder rostrum, equal in length to the front one and kept hidden 


\section{The Nut-Weevil}

away in the abdomen until the moment comes for using it, the mother inserts her egg at the base of the kernel.

I see these nursery precautions only in my mind's eye, but I see them very clearly, enlightened as I am by my examination of the nut converted into a cradle and above all by the method of the Acorn-weevil. Still, I might aim at something better than this; I should like to witness the operation: rather a hopeless ambition, I fear.

In my neighbourhood, indeed, the hazel is scarce and its regular exploiter is almost unknown. Nevertheless, let us make the experiment with the six hazel-trees which I planted in the paddock long ago. First of all we must stock them accordingly.

A valley of the Gard, less parched than the Sérignan hills, provides me with a few couples of the insect. They reach me by post at the end of April, when the nut, still quite light in colour, soft and flattish, is beginning to emerge from the cup in which it is sheathed. The kernel is far from formed; there is just a beginning, a promise of a kernel.

In the morning, in glorious weather, I put 


\section{The Life of the Weevil}

the strangers on the leaves of my hazels. The journey has not tried them unduly. They look splendid in their modest drab costume. The moment they are free, they half-open their wing-cases, spread their wings, fold them again and once again unfurl them, without taking flight. These are mere muscular exercises, serving to revive their strength after a long imprisonment. I regard these sports in the sunlight as a good omen: my colonists will not run away.

Meantime the nuts are filling out daily and beginning to tempt and entice the children. They are within reach of the smallest, who love to stuff their pockets with them and to crunch them, cracking them between two stones. They receive express injunctions to keep their hands off them. This year, for the sake of the Weevils whose history I wish to learn, the joys of gathering nuts in May will be forbidden.

What sort of ideas can such a prohibition produce in these ingenuous minds? If they were of an age to understand me, I would say:

"My dears, beware of the great enchantress, Science. If ever one of you-which 


\section{The Nut-Weevil}

Heaven forbid-should allow himself to be beguiled by her, let him remember my warning: in exchange for the little secrets which she reveals to us, she demands much graver sacrifices than a handful of nuts."

The prohibition is understood; the tempting fruit is left almost untouched. For my part, I inspect the nuts assiduously. All my trouble is unavailing: I do not succeed in surprising a Balaninus engaged in her patient task of boring. At the utmost, at sunset, I happen to see one who, hoisted to her full height, is trying to insert her drill. The little that I observe teaches me nothing new; the Acorn-weevil has already shown me as much.

In any case, it is only a brief attempt. The insect is casting about and has not yet found what suits her. Perhaps the perforator of hazel-nuts works at night.

In another respect I have been more fortunate. Some nuts, some of the first colonized, are laid by in my study and subjected to frequent inspections. My diligence is rewarded with success.

At the beginning of August, two larvæ leave their coffers before my eyes. They 


\section{The Life of the Weevil}

have no doubt long been chipping with the points of their mandibles, that patient chisel, at the hard wall. The exit-hole is just finished when I take note of the coming departure. A fine dust is falling by way of shavings.

The window of release is distinct from the narrow aperture of the entrance. Perhaps it will not do to obstruct this grating, which ventilates the house, while the grub is still at work. The window a foresaid is situated at the base of the fruit, close to the rough surface by which the nut adheres to its cupule. In this region, where the incipient materials are elaborated until the nut is perfectly ripe, the density is a little less than elsewhere. The point to be perforated is excellently chosen therefore: it is here that the least resistance will be encountered.

Without any preliminary auscultation, without exploratory soundings, the recluse knows the weak point of his prison. Confident of success, he works away with a will. Where the first blow of the pick is struck the others follow; no time is wasted on experiments. Persistence is the strength of the weak. 


\section{The Nut-Weevil}

It is done: daylight enters the coffer. The window is opened, round, widening a little inwards and carefully polished over the whole circumference of its embrasure. Under the burnisher of the mandibles any roughness that might presently increase the difficulty of the emergence has disappeared. The holes in our steel draw-plates are scarcely more accurate.

The comparison with a draw-plate comes in quite aptly here: the larva actually frees itself by a wire-drawing-operation. Like a length of brass wire which is reduced by being passed through an orifice too narrow for its diameter, it escapes through the window in the shell by decreasing its girth. The wire is drawn by an exertion on the part of the workman's pincers or by the rotation of the machine; it subsequently retains the reduced thickness which the operation has given it. The grub knows another method: it lengthens and thins itself by its own efforts; and, directly it has passed through the narrow orifice, it returns to its natural size. Apart from these differences the resemblance is striking.

The exit-aperture is precisely the same 


\section{The Life of the Weevil}

width as the head, which, being rigid, with a horny cap, does not lend itself to deformation. Where the head has passed, the body has to pass, however fat it may be. When the liberation is completed, it is most surprising to see how bulky a cylinder, how corpulent a grub has contrived to make its way through the tiny opening. If we had not witnessed the exodus, we should never have suspected such a feat of gymnastics.

The orifice, we were saying, is exactly fitted to the diameter of the head. Now this inelastic head, by whose size that of the hole has been calculated, represents at most one-third of the width of the body. How does a threefold thickness pass through a single calibre?

Here comes the head, without the least difficulty: it is the pattern to which the door was built. The neck, a little wider, follows: a slight contraction frees it. Next comes the turn of the chest and the plump belly. This is a most arduous operation. The grub has no legs. It has nothing, neither hooks nor stiff bristles, that might give it a purchase. It is a soft roly-poly which has, by its own I 28 


\section{The Nut-Weevil}

efforts, to clear the disproportionately narrow passage.

What happens inside the nut escapes me: it is hidden by the opaque shell; what I see outside is very simple and tells me of that which cannot be seen. The creature's blood rushes from back to front; the humours of the organism change their position and accumulate in the part that has already emerged, which swells into a dropsy, attaining five or six times the diameter of the head.

In this way a large cushion is formed on the kerb of the well, a girdle of energy which, by its dilatation and its intrinsic elasticity, gradually extricates the remaining segments, which are diminished in volume by the shifting of their fluid contents.

It is a slow and very laborious business. The grub, in its free part, bends, draws itself up and sways from side to side. We do the same when forcing a nail from side to side to extract it from its socket. The mandibles gape widely, close and gape again, with no intention of laying hold. These movements represent the yo-heave-hoes with which the exhausted creature accompanies its 


\section{The Life of the Weevil}

efforts, like those of sailors hauling on a cable.

"Yo-heave-ho!" says the grub; and the sausage rises a peg higher.

While the extracting pad is swelling and straining every muscle, it is evident that the part still in the shell is draining itself of its humours as far as it possibly can, making them flow into the part released. It is this that makes the wire-drawing action feasible.

One more effort of leverage from the inflated girdle; one more yawn:

"Heave-ho!"

That has done the trick. The grub glides over the shell and drops.

One of the nuts which have just afforded me this sight was gathered on its branch a few hours before. The grub, then, would have fallen to the ground from the height of the hazel-bush. Allowing for the proportions, such a fall would for us mean a terrible crash; for the grub, so plastic and supple, it is a trifle. It matters little to the larva whether it tumbles into the world from the top of the bush or whether it quietly changes its lodgings a little later, when the 


\section{The Nut-Weevil}

nut, fallen of its own ripeness, is lying on the ground.

Without delay, as soon as free, it explores the soil within a restricted radius, seeks a point easy to dig, finds it, does a little spadework with its jaws, wriggles its rump and buries itself. At no very great depth a spherical cavity is made by pressing back the dusty soil. Here the grub will spend the winter and await the resurrection of the spring.

Were I so presumptous as to advise the Balaninus, better-versed than any one in its business as a Weevil, I should say:

"To leave your nut now is an act of folly. Later, when the April festival is here and the hazels replace their drooping catkins by the pink pistils of their nascent fruit, well and good; but to-day, in this time of blazing sunshine, which drives the most gallant workers to idleness, what is the use of deserting a home in which you can sleep so comfortably throughout the slack summer season? Where will you find a better lodging than the shell of a hazel-nut when the autumn rains come and the winter frosts? In what more peaceful solitude could the delicate 


\section{The Life of the Weevil}

work of the transformation be effected? Besides, the subsoil is full of dangers. It is damp and cold; its roughness makes it painful to the touch for a skin as fine as yours. A formidable enemy lurks there, a cryptogam that implants itself upon any buried larva. In my jars I have great diffculty in protecting the buried larvæ which I am trying to rear. Sooner or later white tufts form upon the glass wall, thread-like fluffs whose lower portion will clasp and drain a poor grub turned into a scrap of plaster: it is the mycelium of one of the Sphæriaceæ whose allotted field of exploitation is the bodies of insects undergoing nymphosis underground. In the nut, a hygienic cell, free from devastating germs, nothing of the sort is to be feared. Why leave it?"

These arguments the Balaninus meets with a refusal. It shifts its quarters and it is right. On the ground, where the nut is lying, it has reason, to begin with, to dread the Field-mouse, a great hoarder of nuts. He collects in his stone-heap everything yielded by his nightly rounds; then, at his leisure, with a patient tooth, he pierces a 


\section{The Nut-Weevil}

small hole in the shell and extracts the kernel.

The hazel-nut is a welcome find, a savoury morsel. If emptied by the Weevil, it is only the more valuable: instead of its usual contents it contains the grub of the Balaninus, a rich saveloy which makes a pleasant change from a farinaceous diet. So, for fear of the Field-mouse, we go underground.

A still more important motive urges this departure. True, it would be pleasant to sleep in the impregnable castle of the nutshell; but the delivery of the future insect has also to be thought of. The larva of the Capricorn, throwing caution to the winds, leaves the interior of the oak and comes to the surface, risking the investigations of the Woodpecker; it runs into danger to prepare an exit for the great horned Beetle, who could not make his way out unaided.

A similar precaution is necessary for the Weevil-larva. While possessing the full strength of its mandibles, without waiting for the torpor during which the accumulated fats will be remoulded into a new organism, it pierces the coffer from which the adult would be incapable of escaping by her own efforts; it comes out and buries itself in the 


\section{The Life of the Weevil}

ground. The future is wisely provided against; from its present catacomb the adult will be able without hindrance to ascend to the light of day.

We were saying that, if the Weevil assumed her final shape in the nut, she would be incapable of effecting her own release. Yet with her drill she is very well able to perforate the shell when the egg has to be installed. Why should she be prevented from doing in the inverse direction what she is able to perform inwards from without? A little reflection will show us the tremendous difficulty.

To place the egg in position, a fine tube, of the thickness of the drill, is sufficient. To give passage to the solid adult Weevil would demand a comparatively enormous opening. The material to be pierced is very hard, so hard that the larva, with the powerful gouges of its mandibles, bores a hole only just big enough to allow the head to pass. The rest of the body has to follow by dint of exhausting efforts.

How could the insect open a sufficiently large door with its delicate foil, when the far better-equipped grub has so much 


\section{The Nut-Weevil}

difficulty in boring a moderate porthole? Could she not, by making a ring of perforations, remove a round disk of the requisite size? Strictly speaking, this would be possible, with a prodigious expenditure of patience, a quality which insects can hardly be said to lack.

But here length of time is not enough: the boring-tool is absolutely unmanageable inside the nut-shell. It is so long that, to implant it at the point to be drilled, the Weevil, when she works outside, is obliged to stand erect. For lack of space under the low ceiling of the shell, this position and the alternate tacking about become impossible.

However patient she herself may be and however well-armed we suppose the tip of her drill to be, the Weevil, prevented from employing her augur by the narrowness of the premises, would perish in her coffer. She would die a victim to her inordinate machinery, which serves excellently well for pushing the egg into place, but which would be very unwieldy if the prisoner had to effect her own delivery.

Given a less exaggerated rostrum, just a short and powerful punch, the Weevil, me- 


\section{The Life of the Weevil}

thinks, would not abandon the nut while she was still in the larva stage, the danger of the Field-mouse notwithstanding. It is a delightful laboratory for the remodellingprocess of the metamorphosis. The shell, it is true, lies on the surface of the soil, unsheltered and exposed to the north-wind. But what does the cold matter, provided that we keep dry? The insect has little to fear from the frosts. Its slumbers are all the sweeter when the torpor attending the renewal of its being is increased by the torpor due to a low temperature.

I am persuaded of it: if she carried a less cumbersome drill, the Balaninus would not change her quarters the moment the kernel of her hazel-nut was consumed. My conviction is based on the habits of other Weevils, in particular Gymnetron thapsicola, GERM., who exploits the capsules of a mullein, Verbascum thapsus, LiN., the shepherd's club, a frequent denizen of the tilled fields. As cells these capsules are, though less in volume, almost the equivalent of the hazelnut.

They consist of strong shells, formed of two pieces closely joined, with no communi- 


\section{The Nut-Weevil}

cation whatever with the outside world. A Weevil of humble size and modest attire takes possession of them in May and June as lodgings for her larvæ, which gnaw the placenta of the fruit, laden with unripe seeds.

In August the plant is withered, scorched by the sun, but still standing and topped with its compact spike of capsules. Open some of these shells, almost as solid as cherry-stones. Inside is the Weevil in the adult state. Open them in winter: the Gymnetron has not gone. Open them for the last time in April: the little Weevil is still at home.

Meanwhile, fresh mulleins have sprouted hard by; they flower; their shells attain the right degree of ripeness: the time has come to leave, to go and establish one's family. Not till then does the solitary demolish her hermitage, her capsule, which has protected her so faithfully hitherto.

And how does she do so? It is quite simple. Her rostrum is a short bradawl, easily wielded therefore, even in the confined space of a cell. The shell, moreover, is not too strong. It is a very dry vellum wrapper rather than a hard wooden wall. The recluse drives her short-handled pick 


\section{The Life of the Weevil}

into it; she stabs and thumps and brings the wall crumbling down. And now hurrah for the joys of the sun! Hurrah for the yellow flowers, with stamens all bristling with violet hairs!

Considering their tools, in one case of exaggerated length under a too low ceiling, in another short and suited to the space available in the cell, are not both these insects happily inspired, the first in leaving her nut prematurely, while the grub's powerful shears enable her to do so, the second in spending three parts of the year in the security of her shell, quitting it only at the time of the wedding on the friendly plant? Thus do we see the impeccable logic of the instincts revealed, even in the humblest creatures. 


\section{CHAPTER VII}

THE POPLAR-WEEVIL

GENERALLY speaking, the mother Weevil's attainments are limited to slipping her eggs into places where the grubs will find food to suit them and occasionally, with wonderfully assured botanical tact, to varying the diet. She does little or no industrial work. The niceties of the baby-linen or the feeding-bottle do not concern her. To this uncouth maternity I know but one exception, appertaining to certain Weevils who, in order to endow their young with preserved food-stuffs, have the knack of rolling a leaf, which serves as board and lodging in one.

Among these manufacturers of vegetable sausages the most skilful is the Poplarweevil (Rhynchites populi, Lin:), who is of modest size but splendidly attired. Her back glitters with gold and copper, her abdomen with indigo-blue. Would you see 


\section{The Life of the Weevil}

her at work, you need but inspect the lower twigs of the common black poplar, at the edge of the meadows, about the end of May.

While, overhead, spring's caressing breezes stir the majestic green distaff and set the leaves quivering on their flat stalks, down below, in a layer of calmer air, this year's tender shoots remain quiescent. Here above all, far from the wind-tossed heights uncongenial to the industrious, the Rhynchites labours. And, as the workshop is just at a man's height, nothing is more easy than to watch the roller's actions.

Easy, yes, but distressing, under a blazing sun, if you wish to follow the insect in every detail of its method and the progress of its work. Moreover, this involves long journeys, which take up time; and again it is none too favourable to precise observations, which demand indefinite leisure and assiduous inspections at all hours of the day. It is greatly preferable to pursue our studies in the comfort of our own home; but it is above all things necessary that the insect should lend itself to our plan.

The Rhynchites fulfils this condition I 40 


\section{The Poplar-Weevil}

excellently well. She is a peaceable enthusiast who works on my table with the same zest as on her poplar-tree. A few young shoots, planted in fresh sand, under a wiregauze cover, and renewed as and when they fade, take the place of the tree in my workroom. The Weevil, not in the least intimidated, devotes herself to her industry even under my magnifying-glass and supplies me with as many cylinders as I could wish for.

Let us watch her at work. From this year's growth, sprouting in sheaves at the base of the trunk, she chooses the leaf to be rolled; but she picks it not among the lower leaves, which are already of the usual green and of a firm texture, nor yet among the end leaves, which are still growing. Above, they are too young, not large enough; below, they are too old, too tough, too difficult to manage.

The leaf selected belongs to the intermediate rows. Though still of a doubtful green, in which yellow predominates, soft and shiny with varnish, it has very nearly attained the final dimensions. Its denticulations swell into delicate glandular pads, 


\section{The Life of the Weevil}

whence oozes a little of the viscous matter that smears the buds at the moment when their scales separate.

Now a word on the tools. The legs are provided with two claws shaped like the hook of a steel-yard. The lower side of the tarsi carries a thick brush of white bristles. Thus shod, the insect very nimbly climbs the most slippery perpendicular walls; it can stand and run like a Fly, back downwards, on the ceiling of a glass bell. This characteristic alone is enough to suggest the delicate balance which its work will demand.

The beak, the curved and powerful rostrum, without being exaggerated in size, like those of the Balanini, expands at the tip into a spatula ending in a pair of fine shears. It makes an excellent stylet, which plays the first part of all.

The leaf, as a matter of fact, cannot be rolled in its actual condition. It is a living sheet which, owing to the rush of the sap and the resilience of the tissues, would recover its flatness while the insect was endeavouring to bend it. The dwarf has not the strength to master an object of this size, to roll it up so long as it retains the I42 


\section{The Poplar-Weevil}

elasticity of life. This is obvious to our eyes; it is obvious likewise to the Weevil's.

How is she to obtain the degree of lifeless flexibility required in the circumstances? We might say:

"The leaf must be plucked, allowed to fall to the earth and manipulated on the ground when sufficiently faded."

The Weevil knows more than we do about these things and does not share our opinion. What she says to herself is:

"On the ground, amid the intricate obstructions of the grass, my task would be impracticable. I want elbow-room; I want the thing to hang in the air, free from any obstacle. And there is a more important condition: my larva would refuse a rank, withered sausage; it insists on food that retains a certain freshness. The cylinder which I intend for its consumption must be not a dead leaf but an enfeebled leaf, not entirely deprived of the juices with which the tree supplies it. I must wean my leaf and not kill it outright, so that, when dead, it will remain in its place during the few days of the grub's extreme youth."

The mother therefore, having made her 


\section{The Life of the Weevil}

selection, takes up her stand on the stalk of the leaf and there patiently inserts her rostrum, turning it with a persistency that denotes the great importance of this stilettothrust. A little wound opens, a fairly deep wound, which soon becomes a speck of decay.

It is done: the conduits are cut and allow only a small quantity of sap to ooze into the edge. At the injured point the leaf yields under its own weight; it droops perpendicularly, becomes slightly withered and soon acquires the requisite flexibility. The moment has come for operating on it.

That stiletto-thrust represents, though much less scientifically, the prick of the Hunting Wasp's sting. ${ }^{1}$ The latter wants for her offspring a prey now dead, now paralysed: she knows, with the thoroughness of a consummate anatomist, at what points it behoves her to insert her lancet to procure either sudden death or merely a suppression of movement. The Rhynchites requires for hers a leaf rendered flexible, half-alive,

$1 \mathrm{Cf}$. The Hunting Wasps: passim; also More Hunting Wasps, by J. Henri Fabre, translated by Alexander Teixeira de Mattos: passim.-Translator's Note. 


\section{The Poplar-Weevil}

in a sense paralysed, which can be easily fashioned into a cylinder; she is perfectly familiar with the little leaf-stalk, the petiole, in which the vessels that disperse the energy of the foliage are gathered in a tiny bundle; and she inserts her drill here, here only and never elsewhere. Thus at one blow, without much trouble, she effects the ruin of the aqueduct. Where can the long-nosed insect have learnt her clever trick of dralining springs?

The leaf of the poplar is an irregular rhombus, a spear-head whose sides are expanded into pointed wings. The manufacture of the cylinder begins with one of these two lateral corners, the right or the left indifferently.

Despite the hanging posture of the leaf, which makes the upper or lower surface equally easy of access, the insect never fails to take up its position on the upper side. It has its reasons, dictated by the laws of mechanics. The upper surface, which is smooth and more flexible, has to form the inside of the cylinder; the under surface, which has greater elasticity because of its 


\section{The Life of the Weevil}

powerful veins, has to occupy the outside. The statics of the small-brained Weevils agrees with that of the scientists.

Watch her at work. She is standing on the line along which the leaf is rolled, with three legs on the part already rolled and the three opposite legs on the part still free. Firmly fixed on both with her claws and tufts, she obtains a purchase with the legs on one side while straining with the legs on the other side. The two halves of the machine alternate as motive powers, so that at one moment the shaped cylinder encroaches on the free leaf and at another the free leaf moves and is applied to the cylinder already formed.

There is nothing regular, however, about these alternations, which depend upon circumstances known to the insect alone. Perhaps they merely enable the insect to take a brief rest without suspending a task which does not allow of interruptions. In the same way our two hands mutually relieve each other by taking it in turns to carry a burden.

It is impossible to form an exact image of the difficulties overcome without watching, 


\section{The Poplar-Weevil}

for hours on end, the obstinate straining of the legs, which tremble with exhaustion and threaten to jeopardize everything should one of them let go at the wrong moment, or without seeing how prudently the leaf-roller refrains from releasing one claw until the five others are firmly anchored. On the one hand are three points of support, on the other three points of traction; and the six points are shifted, one by one, little by little, without for an instant allowing their mechanical system to become relaxed. A single moment of forgetfulness or weariness would cause the refractory leaf to unroll its cylinder and escape from the manipulator's grasp.

The work is performed moreover in an uncomfortable position. The leaf hangs, almost or even quite vertically. Its surface is varnished and as smooth as glass. But the worker is shod accordingly. With her tufted soles, she scales polished and perpendicular surfaces; with her twelve meathooks, she grapples the slippery floor.

Yet this fine equipment does not rid the operation of all its difficulties. I find it no easy matter to follow the progress through 


\section{The Life of the Weevil}

the magnifying-glass. The hands of a watch do not move more slowly. For a long while, the insect stands still, at the same point, with its claws firmly fixed: it is waiting for the leaf to take the curve and cease to react. Here, of course, there is no glue to set hard and hold the fresh surfaces stuck together. The stability depends purely on the flexion acquired. And so it is not unusual for the elasticity of the leaf to overcome the worker's efforts and partly to unroll the more or less complete work. Stubbornly, with the same impassive slowness, the insect begins all over again, putting the unsubjected piece back into its place. No, the Weevil is not one to allow herself to be upset by failure: she knows too well what patience and time can do.

As a rule, the Rhynchites works backwards. When her line is finished, she is careful not to abandon the fold which she has just made in order to return to the starting-point and begin another. The part last folded is not yet sufficiently subdued; if left to itself too soon, it might prove rebellious and flatten out again. The insect therefore continues at this extreme point, 


\section{The Poplar-Weevil}

which is more exposed than the rest, and then, without letting go, makes her way backwards to the other end, always with patient deliberation. In this manner, an added firmness is imparted to the new fold; and the next fold is prepared. At the end of the line, there is a fresh prolonged halt and a fresh move backwards. Even so does the husbandman plough the furrows in alternate directions.

Less frequently, no doubt when the leaf is found to be so limp as to entail no risk, the insect abandons the fold which it has just made, without going over it again conversely, and quickly scrambles back to the starting-point to make another.

Here we are at last. Coming and going from top to bottom and from bottom to top, the insect, by dint of stubborn dexterity, has rolled its leaf. It is now at the extreme edge of the leaf, at the lateral corner opposite to that whereat the work began. This is the keystone on which the stability of the rest depends. The Rhynchites redoubles her efforts and her patience. With the tip of her rostrum, expanded spatulawise, she presses, point by point, the edge to 


\section{The Life of the Weevil}

be fixed, even as the tailor presses the rebellious edges of a seam with his iron. For a long, a very long time, without moving, she pushes and pushes, awaiting a proper degree of adhesion. Point by point, the whole welt of the corner is minutely and carefully made fast.

How is adhesion obtained? If only some sort of thread were employed, one might very well regard the rostrum as a sewingmachine, inserting its needle at right angles into the stuff. But the comparison is not permissible: there is no filament employed in the work. The explanation of the adhesion lies elsewhere.

The leaf is young, we said; the fine pads of its denticulations are glands emitting traces of liquid glue. These drops of sticky matter are the gum, the sealing-wax. By the pressure of its beak, the insect makes it flow more abundantly from the glands. It then has only to hold the signet in position and wait for the viscous seal to set. Taken all round, this is our own method of sealing a letter. If it holds ever so lightly, the leaf, losing its resilience as it gradually withers, will soon cease to react and will of itself 


\section{The Poplar-Weevil}

retain the cylindrical shape imposed upon it.

The work is finished. It is a cigar of the diameter of a thick straw and about an inch long. It hangs perpendicularly from the end of the stalk bruised and bent at a sharp angle. It has taken the whole day to manufacture. After a short spell of rest, the mother tackles a second leaf and, working by night, obtains another cylinder. Two in twenty-four hours is as much as the most diligent can achieve.

Now what is the roller's object? Can she be preparing preserves for her own use? Obviously not: no insect, where itself alone is concerned, devotes such care and patience to the preparation of food. It is only with a view to the family that it hoards so industriously. The Rhynchites' cigar forms a dowry for the future.

Let us unroll it. Here, between the layers of the cylinder, is the egg; often there are two, three or even four. They are oval, pale-yellow, like fine drops of amber. Their adhesion to the leaf is very slight; the least jerk loosens them. They are distributed without order, tucked away more or less deeply in the thickness of the cigar and always isolated, one at a time. We find 


\section{The Life of the Weevil}

them in the centre of the scroll, almost at the corner where the rolling begins; we come upon them between the different layers and even near the edge sealed in glue with the signet of the rostrum.

Without interrupting her work on the cylinder, without relaxing the tension of her claws, the mother laid them between the edges of the fold which she was forming, as she felt them coming, duly matured, at the end of her oviduct. She produces life in the very midst of her labours, amid the wheels of the machine which would be thrown out of gear if she snatched a moment's rest. Industry and procreation go hand-in-hand. Short-lived, with but two or three weeks before her and an expensive family to establish, the mother Rhynchites would not dare to waste time in being churched.

This is not all: on the same leaf, not far from the cylinder that is being laboriously rolled, we almost always find the male. What is he doing there, the lazybones? Is he watching the work as a mere onlooker, who happened to be passing and stopped to see the wheels go round? Is he interested 


\section{The Poplar-Weevil}

in the business? Does he ever feel inclined to lend a helping hand in case of need?

One would say so. From time to time I see him take his stand behind his industrious mate, in the furrow of the fold, hang on to the cylinder and join in the work for a little. But it is done listlessly and awkwardly. A bare half-turn of the wheel; and that's enough for him. After all, it is not his affair. He moves away, to the other end of the leaf; he waits, he looks on.

We will give him credit for this attempt, since paternal assistance in settling the family is rare among insects; we will congratulate him on the help which he gives, but not to excess: his assistance is interested. It is a means of declaring his flame and urging his merits.

And in fact, after several refusals notwithstanding the advances made during a brief collaboration on the cylinder, the impatient suitor is accepted. Everything takes place on the site of the female's labours. For ten minutes or so, the rolling is suspended, but the worker's legs, violently contracted, are very careful not to let go: 


\section{The Life of the Weevil}

were their effort to cease, the cylinder might at once come unrolled. There must be no interruption of work for this brief diversion, the insect's only enjoyment.

The stoppage of the machine, which remains tense in order to keep the recalcitrant roll in subjection, is soon over. The male retires to a little distance, without quitting the leaf, and the task is resumed. Sooner or later, before the seals are set upon the work, a fresh visit is paid by the dawdler, who, under pretence of assisting, comes running up, -sticks his claws for a moment into the partly-rolled piece, plucks up courage and renews his exploits with as much liveliness as though nothing had yet occurred. And this is repeated three or four times during the making of a single cigar, so much so that we begin to wonder whether the laying of each egg may not require the direct cooperation of the insatiable swain.

It is true that numerous couples are formed in the sunlight, on the leaves not yet punctured. Here the nuptial gambols are really a frolic unaffected by the stern demands of labour. The insects revel un- 


\section{The Poplar-Weevil}

reservedly, hustling their rivals off the field and browsing on half the thickness of a leaf which becomes furrowed with bare streaks resembling a freakish handwriting. The fatigues of the workshop are preceded by merry-making in gay company.

According to the rules of entomology, once these rejoicings are over, all should be quiet again and each mother should get to work on her cigars without further disturbance. In this case the general law relents. I have never seen a cylinder formed without a male lurking in the neighbourhood; and, if I had the patience to wait, I should not fail to witness repeated pairings. These weddings renewed for each egg puzzle me. Where, on the faith of the text-books, I looked for a single mating, I find an indefinite number.

This is not an isolated instance. I will mention a second, which is even more striking. It is supplied by the Capricorn (Cerambyx heros). I rear a few couples in captivity, with sliced pears for food and with oak billets wherein to lay the eggs. The pairing is continued during almost the whole of July. For four weeks the long- 


\section{The Life of the Weevil}

horned Beetle does nothing but mount his mate, who, gripped by her rider, wanders at will and, with the point of her oviscapt, selects the fissures in the bark best-suited to receive the eggs.

At long intervals, the Cerambyx steps off and goes to refresh himself on a piece of pear. Then suddenly he stamps his feet as though he had gone mad; he returns with a frantic rush, clambers into the saddle and resumes his seat, of which he makes free use at all hours of the night and day. At the moment when the egg is being placed in position, he keeps quiet; with his hairy tongue he polishes the egg-layer's back, which is a Capricorn's way of caressing; but the next instant he renews his attempts, which are usually followed by success. There is no end to it!

The pairing continues in this manner for a month; it does not cease until the ovaries are exhausted. Then, mutually worn out, having no further business on the trunk of the oak, husband and wife separate, languish for a few days and die.

What conclusion are we to draw from this extraordinary persistency in the Cerambyx, 156 
The Poplar-Weevil

the Rhynchites and many others? Simply this: our truths are but provisional; assailed by the truths of to-morrow, they become entangled with so many contradictory facts that the last word of knowledge is doubt. 


\section{CHAPTER VIII}

THE VINE-WEEVIL

IN the spring, while the poplar-leaves are 1 being worked into cylinders, another Rhynchites, who is likewise magnificently attired, is making cigars out of vine-leaves. She is a little bigger, of a metallic lustre, a golden green that changes to blue. Were she only larger, the resplendent Vine-Weevil would occupy a very respectable place among the gems of entomology.

To attract our eyes, she has something better than her brilliancy: she has her industry, which has earned her the hatred of the vine-grower, jealous of his property. The peasant knows her: he even calls her by a special name, an honour rarely bestowed in the world of the smaller creatures.

The rural vocabulary is rich in names of plants, but very poor in names of insects. A couple of dozen words, inextricably confused because of their general character, represent I58 


\section{The Vine-Weevil}

the whole list of insect names in our Provençal idiom, expressive and fertile though this idiom be when it refers to the vegetable world and even, at times, to a sorry weed which one would think was known to the botanist only.

The man of the soil is interested above all things in the plant, the great foster-mother; all else leaves him indifferent. Splendid adornment, curious habits, marvels of instinct: all these make no appeal to him. But to touch his vine, to eat other people's grass: what a heinous crime! Quick, a name, a badge of infamy, to hang round the malefactor's neck!

This time the Provençal peasant has taken the trouble to invent a special term: he calls the cigar-roller the Bécaru. Here the scientific name and the rural name are in complete agreement. Rhynchites and Bécaru are exact equivalents: both allude to the insect's long beak.

But how much more correct is the vinegrower's term, in its lucid simplicity, than the scientific name, set forth in full, with its imperative complement relating to the species! I rack my brain in vain to guess 


\section{The Life of the Weevil}

the reason why the cigar-roller of the vine was called the Rhynchites of the Birch ( $R$. betuleti, FAB.).

If there be in fact a Weevil that exploits the birch-tree, it is certainly not the same as that of the vineyards: the two leaves to be rolled are too dissimilar in shape and size to suit the same worker.

Recorders of descriptions, you who, under the scrupulous eye of the magnifying-glass, specify the shapes and establish the identity of the animal species, before you give names and surnames to your impaled insects, pray, pray enquire a little into their manner of life. By so doing, you will see things more clearly, you will avoid much detestable nonsense and you will spare the novice such doubts as those which obsess him when he finds himself obliged to label a Weevil inhabiting the vine-branches as a Rhynchites of the Birch. We are ready to excuse cacophonous syllables and grating consonants; but we reject with exasperation a name that misrepresents the facts.

In her work the Vine-Weevil pursues the same method as the Poplar-Weevil. The leaf is first pricked with the rostrum at I60 


\section{The Vine-Weevil}

a point on the stalk, which checks the flow of the sap and makes the edges of the faded leaf pliable. The rolling begins at the angle of one of the lower lobes, with the smooth, green upper surface inside and the downy, strongly-veined lower surface outside.

But the great size of the leaf and its deeply indented outline hardly ever allow of regular work from one end of the leaf to the other. Over and over again, sudden folds occur and alter the direction of the rolling, leaving now the green and now the downy surface outside, without any appreciable design, as though by chance. The poplar-leaf, with its simple form and its moderate size, yields an elegant cylinder; the vine-leaf, with its cumbersome width and complicated outline, produces a shapeless cigar, an untidy bundle.

This is not due to defective talents, but to the difficulty of manipulating and controlling a leaf of this kind. The mechanical method, indeed, is the same as that practised on the poplar-leaf. With three legs here and three legs there on the edges of the fold, the Bécaru obtains a purchase on one side and tugs and strains on the other. 


\section{The Life of the Weevil}

Like her rival 'cigar-maker, she works backwards, keeping her eyes upon the part which, folded that moment and still unset, may require immediate touching up. The product is thus watched until it gives proof of its stability.

Like the other, she too seals the denticu. lations of the final layer by pressing them with her rostrum. Here there is no sticky secretion oozing from the edges of the leaf, but there is a downy fluff whose fibres get entangled and cause adhesion. On the whole, therefore, the method employed by the two Rhynchites is the same.

Nor do their domestic habits differ. While the mother is patiently rolling her cylinder, the father remains close at hand, on the same leaf. He looks on. Next, he comes running along in a hurry, takes his stand in the crease and kindly lends the assistance of his grappling-irons. But he again is not a very diligent helper. His brief collaboration is a pretext to tease the worker and achieve his ends by sheer persistence.

He retires satisfied. Let us watch him. Before the roll is finished, we shall see him 162 


\section{The Vine-Weevil}

return many times, inspired by the same intentions, which are rarely scorned. I need not insist further on these pairings, which are repeated indefinitely and run counter to the classic data on one of the nicest points of insect physiology. To impress the seal of life upon the hundreds of eggs of the mother Bombyx, ${ }^{1}$ or the thirty thousand or more of the mother Bee, the father exerts only one direct intervention. The Weevil claims the privilege of intervening for almost every egg. I leave the curious problem to the experts. Let us unroll a recently-made cigar. The eggs, fine, amber-coloured beads, are scattered, one by one, at very different depths in the spiral. As a rule, I find several, from five to eight. The multiplicity of fellowfeasters, in both the rolled poplar-leaf and the rolled vine-leaf, bears witness to extreme frugality.

The two leaf-rollers are quickly hatched: the grub is born in five or six days' time. Then the observer begins to be faced with the same difficulties that beset a prentice hand in the rearing of larvæ; and these difficulties are all the more exasperating in

1 The Silk-worm Moth.-Translator's Note. 


\section{The Life of the Weevil}

that there was nothing to predict them. The course to be followed here seems indeed so very simple.

Since the rolled leaves are at the same time board and lodging, we have but to pick them, from the vine and the poplar respectively, and to place them in the glass jars, whence we can take them at such times as we consider suitable. What used to be effected in the open air, amid the disturbances of the atmosphere, will be effected all the better in the peaceful shelter of the glass. There can be no doubt, therefore, of an easy success.

But what is this? From time to time I unroll a few cigars to ascertain the state of their contents. What I see fills me with anxiety for the fate of my baby-farm. The young larvæ are very far from thriving. I find some of them languishing and emaciated, shrivelling into a wrinkled ball; I find some of them dead. Vainly I possess myself in patience: the weeks go by and not one of my grubs grows or gives a sign of energy. From day to day my two colonies dwindle until they consist wholly of dying larvæ. 


\section{The Vine-Weevil}

When July comes, there is not a living thing left in my glass jars.

All have died. And of what? Of starvation, yes, of starvation in a well-stored granary. This is evident from the small amount of food consumed. The cylinders are almost untouched; at most I perceive in the midst of their layers a few scratches, the traces of a scornful tooth. Probably the food was too dry, had been rendered uneatable by dessication.

Under natural conditions, while the burning heat of the sun hardened the leaves by day, the mists and the dew softened them at night. Thus, in the heart of the spiral layers, a column of soft crumb is preserved, a necessity for the tender nurselings. A sojourn in the uniformly dry atmosphere of the jars has, on the other hand, turned the roll into a hard, stale crust which the grubs refused to touch. The failure is due to that.

A year later, I begin again, this time more cautiously. The rolled leaves, I said to myself, remain hanging for some days on the vine or the poplar. The perforation of the leaf-stalk has not completely severed the 165 


\section{The Life of the Weevil}

ducts conveying the sap; a scanty flow still persists and for some time maintains a certain flexibility in the leaf, especially in the centre of the spiral, which is not exposed to the action of the sun. Consequently the newborn grub has fresh provisions within reach of its mandibles. It waxes big and strong and acquires a stomach able to satisfy itself with less tender food.

Meantime, from day to day, the roll turns brown and dry. If it remained indefinitely hanging on the bough and if, as often happens, there were a lack of moisture at nights, it would dry up completely and its inmates would perish as they did in my glass jars. But, sooner or later, the wind shakes them off and they drop to the ground.

Their fall is the salvation of the grub, which is still very far from full-grown. At the foot of the poplar, under the grass of the meadow subject to frequent irrigation, the soil is always damp; at the foot of the vine-stock, the earth, overshadowed by the branches, fairly well retains the moisture of the last showers. Lying in the wet and sheltered from the direct onslaughts of the 


\section{The Vine-Weevil}

sun, the Rhynchites' victuals remain as soft as need be.

Thus I argued, meditating a fresh experiment; and the facts confirmed the accuracy of my forecast. This time all goes well. Rather than the green rolls of recent manufacture, I gather the brown cigars which are due to fall to the ground. The larvæ in these latter, being older, are less difficult to rear. Lastly, my harvest is installed in glass jars as before, but on a bed of moist sand. With this and this alone I achieve complete success.

Despite the mildew which this time invades the heaped cigars and seems bound to jeopardize everything, the larvæ thrive and grow without hindrance. The decay which I distrusted so much in the beginning, when I kept my crops dry to avoid it, this decay suits them. I see them taking big mouthfuls of decomposing shreds, the tainted remains of leaves that have almost turned to mould.

I am no longer surprised that in my first experiments my nurselings allowed themselves to die of hunger. Obeying a mistaken 


\section{The Life of the Weevil}

idea of hygiene, I took pains to keep the rations in good condition, in an atmosphere free from mustiness. I ought, on the contrary, to have allowed fermentation to do its work, softening the tough tissues and enhancing their flavour.

Six weeks later, in the middle of June, the oldest rolls are dilapidated hovels, retaining scarcely a trace of their cylindrical form save the outer layer, a protecting roof. Let us open one of these ruins. Inside, there is absolute wreck, a mixture of shapeless remnants and black granules, like fine gunpowder; outside, a crumbling envelope, pierced here and there with holes. These openings tell me that the inhabitants have departed and made their way underground.

I find them, in fact, in the layers of moist sand with which the jars are provided. Pushing and heaving with their backs, they have each dug themselves a round hollow, taking up the least possible room, in which the grub, rolled into a bunch, makes ready for its new life.

Though formed of sandy particles, the wall of the cell does not threaten to collapse. Before lapsing into the sleep of the trans168 


\section{The Vine-Weevil}

formation, the recluse has deemed it prudent to strengthen its house. With a little care, I am able to detach the dwelling in the form of a little ball the size of a pea.

I then discover that the materials are cemented by means of a gummy produce which, liquid at the moment of its emission, has penetrated to a sufficient depth and welded the sandy grains into a wall of a certain thickness. This product, which is colourless and not very plentiful, leaves me in doubt as to its origin. It certainly does not come from glands similar to the silk-tubes of the caterpillars; the Weevil-grub possesses nothing of that kind. It is, therefore, a contribution from the digestive canal, presented through either the entrance or the exit-door. Which of the two?

Without completely solving the question of this cement, another Weevil supplies a fairly probable answer. This is Brachycerus algirus, FAB., an ugly, unwieldy insect, covered with little warts each ending in a claw-like horn. It is soot-black and almost always soiled with earth, when you meet it in spring. This dusty garb denotes a tunneller.

The Brachycerus, in fact, haunts the sub169 


\section{The Life of the Weevil}

soil, hunting for garlic, the exclusive food of her larva. In my modest kitchen-garden, garlic, dear to the Provence folk, has its special corner. At the time when we gather it, in July, most of the heads give me a mag. nificent grub, fat as butter, which has dug itself a large hollow in one of the cloves, only one, without touching the rest. This is the grub of the Brachycerus, which discovered the aioli of the Provençal cooks long before they did.

Raw garlic, Raspail ${ }^{1}$ used to say, is the camphor of the poor. The camphor possibly, but not the bread. This paradox becomes a reality in the case of our grub, which is so much in love with this powerful condiment that it will not eat anything else its whole life long. How, with this fiery diet, does it put on such fine layers of fat? That is its secret; and there is room for every sort of taste in this world of ours.

After eating its clove, this lover of garlic dives deeper into the soil, fearing perhaps the lifting of the bulbs, the time for which

1 François Vincent Raspail (1794-1878), a French physician and politician, one of the early advocates of universal suffrage.-Translator's Note. 


\section{The Vine-Weevil}

will soon arrive. It foresees the annoyance which the market-gardener would cause it; and it goes below, far from the natal plant.

I have reared a dozen in a jar half full of sand. Some have established themselves right against the wall, which enables me to obtain a vague idea of how things happen in the underground cell. The builder is bent into a bow which now and again closes and forms a circle. I then seem to see it collecting, with the tips of its mandibles, as the Larini do, a sticky drop which forms at its hinder end. With this it soaks the sandy wall and smears the glass, on which the stuff hardens in cloudy streaks, white and paleyellow.

On the whole, the appearance of the cement employed and the little that I can see of the grub's proceedings incline me to believe that the Brachycerus strengthening its cabin uses the same method as the Larinus building its thatched hut. The Brachycerus also knows the whimsical secret of turning the intestine into a factory of hydraulic cement. The sandy agglomerate thus obtained forms a fairly solid shell, in which the insect, which reaches the adult stage in 


\section{The Life of the Weevil}

August, remains until the garlic season is at hand.

This method may well be general among the various Weevils that, in the larval, nymphal or adult state, spend part of the year tucked away in an underground shell. The leaf-rollers, notably the Rhynchites of the poplar and the vine, sparing though they be in the use of their cement, no doubt have a store of it in their intestine, for it would be difficult for them to find anything better. Let us, however, leave a door open to doubt and continue.

For the first time, at the end of August, four months after the rolling of the cigars, I take the Poplar-weevil in her adult form out of her shell. I disinter her in all her gleaming gold and copper; but the beauty, if I had left her undisturbed, would have slept in her subterranean fortress till the young leaves sprouted on her tree, in April.

I disinter others, soft and quite white, whose limp wing-cases open to allow the crumpled wings to spread. The most advanced of these pale sleepers boast, by way of a startling contrast, a deep-black rostrum with violet gleams. The Sacred Beetle, in I72 


\section{The Vine-Weevil}

the early days of his final form, begins by hardening and colouring his implements of labour: the toothed arm-pieces and the clypeus with its semicircular notching. The Weevil likewise in the first place hardens and colours her drill. These industrious workers interest me with their preparations. Barely has the rest of the body set and crystallized before the tools of its future work acquire exceptional strength, which they owe to an early and long protracted tempering.

From the broken shells I also take nymphs and larvæ. The latter apparently will not pass beyond the first stage this year. What is the use of hurrying? The larva, no less than the adult and perhaps more so, is given to slumbering through the severities of the winter. When the poplar unfurls its sticky buds and the Cricket on the greensward strikes up the first bars of his melody, they will be ready, one and all: the forward and backward alike; faithful to the call of spring, all will come forth from the ground, eager to climb the kindly tree and to renew the leaf-rollers' festival in the sunlight.

In its pebbly, parching soil, on which the 173 


\section{The Life of the Weevil}

food-cylinders dry up so quickly, the Vineweevil lags behind, exposed as she is to periods of unemployment due to the absence of properly softened food. It is in September and October that I obtain the first adults, splendid gems, enclosed, until spring, in their casket, the underground shell. At this season there is an abundance of buried nymphs and larvæ. Many of the grubs even have not yet left their cylinders; but, to judge by their size, they will hardly linger much longer. At the first frosts, all will become torpid and postpone their further development until the end of the winter. 


\section{CHAPTER IX}

\section{OTHER LEAF-ROLLERS}

I the insect's trade determined by the 1 nature of the tools of which it disposes, or, on the contrary, is it independent of them? Does the organic structure govern the instincts, or do the insect's various aptitudes hark back to origins that cannot be explained merely by the details of its anatomy? We shall obtain an answer to these questions from two other leaf-rollers, the Apoderus of the Hazel ( $A$. coryli, LiN.) and the Attelabus (A. curculionoides, LiN.), both of them eager rivals of the cigar-makers who work the poplar and the vine.

According to the Greek lexicon, the term Apoderus ought to mean "the flayed." Is this really what the author of the expression had in mind? My few books, the odd volumes of a village naturalist, do not enable 


\section{The Life of the Weevil}

me to reply. However, to me the word is explained by the insect's colour.

The Apoderus is a skinless creature, displaying its naked and bleeding misery. Its colour is vermilion, as bright as sealingwax. It is like a drop of arterial blood coagulated on the dark green of a leaf.

To this loud costume, rare among insects, are added other, equally unusual characteristics. The Weevils are all microcephalous. This one exaggerates the absurd disproportion even further: she retains only the indispensable minimum of a head, as though she were trying to do without one altogether. The cranium in which her poor brain is lodged is a paltry, glittering, jet-black speck. In front of this speck is no beak, but a very short, wide snout; behind is an unsightly neck, which one might imagine to have been strangled in a halter.

Standing high on her legs, clumsy in her gait, she ambles step by step across her leaf, which she pierces with round windows. The material removed is her food. Faith, a strange creature: a reminiscence, may be, of some ancient mould, cast aside by life's progress! 


\section{Other Leaf-Rollers}

Three Apoderi and no more figure in the European fauna. The best-known is that of the hazel. This is the one to whom I propose to devote my attention. I find her here, not on the hazel, her lawful domain, but on the common alder. This change in her activities deserves a brief investigation.

My district does not suit the hazel very well; the climate is unfavourable, being too hot and dry. On the high slopes of Mont Ventoux it grows sparsely; in the plain, except in the gardens where a few find a footing, they are no longer to be seen. In the absence of the fostering bush, the insect, without becoming impossible, is at least extremely rare.

Long though I have been beating the brambles of my countryside over an umbrella held upside down, here is our Apoderus for the first time. For three springs in succession I see the red Weevil on the alder and observe her work. One tree, one alone and always the same, in the osier-beds of the Aygues provides me with this leaf-roller, whom I now for the first time see alive. The other alders round about have not a trace of her, though they are only a few 


\section{The Life of the Weevil}

yards distant. There is here, on this privileged tree, a small, accidental colony, a settlement of foreigners, who are becoming acclimatized before extending their domain.

How did they come here? Undoubtedly brought by the torrent. The geographers call the Aygues a water-course. As an eyewitness, I should call it, more accurately, a pebble-course. Understand me: I do not mean that the dry pebbles flow down it of themselves; the low gradient does not permit of such an avalanche. But only let it rain; and they will stream fast enough. Then I can hear the roar of the grinding stones from my house, a mile and a quarter distant.

During the greater part of the year, the Aygues is a broad expanse of white pebbles; of the torrent naught remains but the bed, a furrow of enormous width, comparable with that of its mighty neighbour, the Rhone. Let the rain fall persistently, let the snows melt on the slopes of the Alps; and the thirsty furrow fills for a few days: roaring, it overflows to a great distance and turbulently shifts its shoals of pebbles. Return a week later. The roar of the flood is succeeded by silence. The terrible waters 178 


\section{Other Leaf-Rollers}

have disappeared, leaving on the banks, as the trace of their brief passage, wretched muddy puddles soon absorbed by the sun.

These sudden freshets bring a thousand live gleanings swept off the flanks of the mountains. The dry bed of the Aygues is a most interesting botanical garden. There you may gather many vegetable species brought down from the higher levels, some temporary, disappearing without offspring in a single season, others persisting and adapting themselves to the new climate. They come from far away, from the heights, these exiles; to pluck this one or that in its true environment you would have to climb Mont Ventoux, pass beyond the zone of the beeches and reach the altitude where trees cannot grow.

Alien zoology in its turn is represented in the osier-beds, whose calm is disturbed only during unusually prolonged floods. My attention is attracted especially by the landmollusc, that champion stay-at-home. In stormy weather, when the thunder growlslou tambour di cacalauso, as the Provençal calls it-the most that the Snail permits himself in the matter of moving about is to issue 


\section{The Life of the Weevil}

from his stronghold, some crevice in the rocks, and to browse before his door upon the grasses, mosses and lichens made tender by the flood. It takes a cataclysm to make that one travel!

The wild freshets of the Aygues succeed in doing so. They bring into my part of the world and deposit in the osier-thickets the largest of our Snails, Helix pomatia, the glory of Burgundy. ${ }^{1}$ Rolled down the grassy mountain-slopes by the showers, the exile defies immersion within the water-tight cover of his chalky operculum; he endures the jolting, thanks to his strong shell. He travels by stages, from one osier-bed to another. He descends as far even as the Rhone and colonizes the Île des Rats and the Île du Colombier opposite the mouth of the Aygues.

Whence does he come, this enforced emigrant, whom one would vainly seek elsewhere in the land of the olive? He loves a moderate temperature, green turf, cool shades. His place of origin is certainly not

1 H. pomatia is the Large Edible Snail.—Translator's Note. 


\section{Other Leaf-Rollers}

here, but far away on the rounded heights of the lower, outermost Alps. The highlander's exile none the less seems pleasant. The big Snail does quite well in the marshy scrub on the banks of the torrent.

Neither is the Apoderus a native. She is a castaway, hailing from the hazel-clad heights. She has made the voyage in a little boat, that is to say, in the leafy cockleshell in which the grub is born. The vessel was tightly closed, which made the passage possible. Running ashore at some point on the bank in the height of summer, the insect perforated its cell and, not finding its favourite tree, established itself upon the alder. There it founded a family, remaining faithful to the same tree for the three years during which I had to do with it. It is probable, for that matter, that the origin of the settlement dates farther back.

The history of this stranger interests me. The primordial conditions of her lifeclimate and food-are changed. Her ancestors lived under a temperate sky; they grazed on the leaf of the hazel-bush; they manufactured cylinders out of piece-goods 


\section{The Life of the Weevil}

made familiar by the constant practice of past generations. But the wanderer is living under a torrid sky; she grazes on the alderleaf, whose flavour and nutritive properties must differ from those of the family diet; she works at an unknown piece, though it is not unlike the normal piece in shape and size. What changes has this disturbance of its diet and climate effected in the insect's characteristics?

Absolutely none. In vain I pass the magnifying-glass over the exploiter of the alder and over the exploiter of the hazelbush, of whom the latter has reached me from the heart of the Corrèze by post. I see not the least difference between the two, even in the smallest details. Can the method of the industry have been modified? Without seeing the work done with a hazelleaf, I boldly assert that it is similar to that obtained with an alder-leaf.

Change the food and the climate, change the materials to be worked: if it can adapt itself to the new conditions imposed upon it, the insect persists, immutable in its craft, habits and organization; if it cannot, it dies. To be as one was or not to be: that is what 182 


\section{Other Leaf-Rollers}

the castaway of the torrent, like so many others, tells us.

Let us watch her at work on the alder and we shall know how she labours on the hazelbush. The Apoderus does not know the method of the Rhynchites, who, to kill the elasticity of the leaf to be rolled, makes a deep puncture in the stalk. The red leafroller has a special modus operandi, in no way related to that of the puncture.

Can this change of method be due to the absence of the rostrum, of the fine awl capable of being driven into the narrow leafstalk? It is possible, but not certain, for the snout, an excellent pair of shears, could cut half through the leaf-stalk at a bite and obtain an equivalent result. I prefer to see in the novel procedure one of those methods which are the separate property of every specialist. We must never judge of the work by the tool employed. The insect is an adept at using any sort of implement, even though defective.

The fact is that with her mandibles the Apoderus slashes the alder-leaf cross-wise, at some distance from the base. The whole leaf is cut clean through, including even the 183 


\section{The Life of the Weevil}

central vein. The only part left intact is the extreme edge, from which the large severed area hangs withering.

This area, the greater part of the leaf, is then folded in two along the principal vein, with the green or upper surface inside; then, starting from the tip, the folded sheet is rolled into a cylinder. The orifice above is closed with that part of the border which the cut has left untouched; the orifice below is closed with the edges of the leaf tucked inwards.

The pretty little barrel hangs perpendicularly, swaying to the least breeze. It is hooped by the median vein, which projects at the upper end. Between the second and third pages, as it were, of the double sheet, near the middle of the spiral, is the egg, resin-red and, this time, single.

The few cylinders which I have been able to examine afford me no circumstantial details touching the development of their inmate. The most interesting fact which I learn from them is that the grub, when it has attained its full growth, does not go underground as the others do. It remains in its barrel, which the wind soon shakes I 84 


\section{Other Leaf-Rollers}

down into the grass. That half-decayed shelter would be very unsafe in bad weather. The red Weevil knows this. She hastens to assume her adult form, to don her scarlet cloak; and by the beginning of summer she abandons her cylinder, now a mere wreck. She will find a better refuge under the loose strips of old bark.

Attelabus curculionoides is no less expert in the art of making a keg out of a leaf. There is one curious point of resemblance: the new cooper is red, like the other, or, more accurately speaking, crimson. The rostrum is very short and expanded into a snout. Here the likeness ceases. Our first friend is rather fine-drawn and loose-limbed; the second is a thickset, round, dumpy Weevil. We are quite surprised by her work, which seems incompatible with the worker's awkward, clumsy build.

And she does not work a docile stuff either: she rolls ilex-leaves, young ones, it is true, not yet too stiff. It is a tough material all the same, difficult to bend and slow in fading. Of the four leaf-rollers of my acquaintance, the smallest, the Attelabus, has the hardest lot; nevertheless, it is she, 185 


\section{The Life of the Weevil}

the dwarf, such a bungler in appearance, who by dint of patience builds the prettiest house.

At other times she exploits the common oak, the English oak, whose leaves are broader and more deeply indented than those of the ilex, or holm-oak. On the spring shoots she selects the topmost leaves, of average size and medium consistency. If the position suit her, five, six or more little kegs will be dangling from the same twig.

Whether it settle on the holm-oak or on the common oak, the insect begins by incising the leaf, at some distance from the base, to the right and left of the median vein, while respecting the vein itself, which will provide a solid attachment. Then the Apoderus' method is repeated: the leaf, rendered more tractable by the two incisions, is foldeid lengthwise, with the upper surface inside. All these leaf-rollers, cigar-makers and coopers alike, know how to overcome the resilience of a leaf by means of punctures or incisions; all are thoroughly versed in that principle of statics according to which the surface whose elasticity is the greater will be found on the convex aspect of the curve. 


\section{Other Leaf-Rollers}

Between the two sheets which touch, the egg is laid, again one egg. Then the double leaf is rolled from the tip to the attachment. The indentations, the serrations of the last fold are sealed down by the patient pressure of the snout; the two mouths of the cylinder are closed by turning the edges in. It is finished. The barrel is completed, about two-fifths of an inch long and hooped at its fixed end by the median vein. It is small but strong and not devoid of elegance.

The thick-set cooper has her merits, which I should like to elucidate more fully by watching her at work. What I have contrived to see in the open, in the actual workshop, amounts to little more than nothing. Many a time do I surprise the Weevil on her cask, motionless, with her snout against the staves. What is she doing there? She is sleeping in the sunlight; she is waiting for the last layer of the work to acquire a firm hold under prolonged pressure. If I examine her too closely, she at once gathers her legs under her belly and lets herself fall.

Since my visits tell me hardly anything, I try to rear the insect in domesticity. The Attelabus lends herself very well to the 187 


\section{The Life of the Weevil}

attempt: she works under my bell-jars as zealously as on her oak. What I now learn deprives me of all hope of following the details of the leaf-rolling process: the Attelabus is one of those who work at night.

Late in the evening, about nine or ten o'clock, she gives the cuts of the scissors that slash the leaf; next morning, the keg is finished. Seen by the uncertain light of a lamp and at untimely hours, hours rightly claimed by sleep, the worker's delicate technique would escape me. We will give up the idea.

There is a reason for these nocturnal habits. I think I see what it is. The leaf of the oak, especially of the holm-oak, is much harder to bend than the leaf of the alder, the poplar or the vine. If rolled in the daytime, under the burning rays of the sun, it would add to the difficulties arising from indifferent flexibility those due to incipient dryness. On the other hand, when visited by the dew, in the coolness of the night, it will remain pliable; it will yield adequately to the efforts of the roller; and the barrel will be ready when the sun comes, 


\section{Other Leaf-Rollers}

with its blazing heat, to steady the shape of the still moist fabric.

However different one from the other, the four leaf-rollers have shown us that the individual craft is not a matter of organic structure, that the tool does not determine the nature of the work. Whether endowed with a rostrum or a snout, whether longlegged or slow, slender or thick-set, perforators or cutters-out, they all four achieve the same result, the cylinder that acts as a shelter and a larder for the grub.

They tell us that instinct has its origin elsewhere than in the organs. It goes farther back; it is inscribed in the primeval code of life. Far from being dependent on the tools, it commands them and is able to employ them as it finds them, with the same skill, for one task here and for another there.

The little cooper of the oak-tree has not finished with her revelations. Having observed her pretty frequently, I know how fastidious she is of the quality of her victuals. If they be dry, she refuses them absolutely, even though it means dying of starvation. She wants them tender, pickled in moisture, 


\section{The Life of the Weevil}

softened by incipient decay, even seasoned with a touch of mildew. I prepare them to her liking by keeping them in a jar on a bed of moist sand.

Thus treated, the grub hatched in June soon increases in size. Two months are enough to turn it into a handsome orangeyellow larva, which, when its cell is broken open, suddenly, with the violence of a spring released, straightens its curved body and tosses about. Observe its slender form, much less stout than that of the other Weevils in general. This is the only instance in which lack of corpulence in the larva denotes an adult of an exceptional class. I shall say no more on the subject of the grub: its description would be of no particular interest.

The matter deserves looking into more closely. It is the end of September; we have been suffering from an extraordinarily hot and dry summer. The dog-days seem determined to last for ever. The forests are ablaze in the Ardèche, the Bordeaux and the Roussillon districts; whole villages have been burnt down on the slopes of the Alps; in front of my door, a careless passer-by, throw- 


\section{Other Leaf-Rollers}

ing away a match, sets fire to the neighbouring meadows. You cannot call it a summer : it is a conflagration.

What can the Attelabus be doing in such disastrous weather? She is thriving comfortably in my jars, which keep her victuals soft for her; but, at the foot of her oak, amid the undergrowth shrivelled as though by the breath of a furnace, on the calcined earth, what becomes of the poor thing? Let us go and see.

Beneath the oaks which she was exploiting in June, I succeed in finding, among the dead leaves, a dozen of her little barrels. They have retained their green colour, so suddenly did the dessication seize them. They crack and crumble into dust under the pressure of the fingers.

I open a barrel. In the middle is the grub, looking fit enough, but how small! It is hardly larger than when it left the egg. Is it dead or alive, this yellow atom? Its immobility proclaims it to be dead; its unfaded colour proclaims it to be alive. I break open a second barrel, a third. In the middle there is always a yellow grub, motionless and quite small, as though newly-born. 


\section{The Life of the Weevil}

We will stop at this and keep the rest of my collection for an experiment that occurs to my mind.

With their mummy-like immobility, are the grubs really dead? No; for, if I prick them with the point of a needle, they twitch immediately. Their condition is merely one of arrested development. In their freshlyrolled sheath, still hanging from the tree and receiving a little sap, they found the food necessary for their early growth; then the barrel fell to the ground, where it soon dried up.

Then, disdaining its hard provender, the grub ceased to eat and grow. Who sleeps dines, so the proverb says; and it is waiting in a state of torpor for the rain to soften its bread.

This rain, for which man and beast have been sighing for four months past, I have it in my power to realize, at least to the limits of a Weevil's requirements. I float the rest of the dry barrels in water. When they are thoroughly soaked, I transfer them into a glass tube, closed at either end with a plug of wet cotton-wool which will keep the atmosphere moist. 


\section{Other Leaf-Rollers}

The result of my stratagems deserves mention. The sleepers awake, eat the inside of the softened loaf and make up so well for lost time that in a few weeks they are as large as those which have not suffered any interruption in my jars half full of moist earth.

This knack of suspending life for months at a time, when the provisions have lost the requisite tenderness, is not repeated in the other leaf-rollers. At the end of August, three months after the hatching, there is nothing left alive in the cigars of the vine which have been allowed to dry. Death is even swifter in the withered cigars of the poplar. As for the cylinders of the alder, in the absence of a sufficient number of leaves, I was not able to estimate their inhabitants' powers of endurance.

Of the four leaf-rollers, the one most threatened by drought is that of the oak. Her barrel falls and lies on a soil which is extremely arid except at times of rain; moreover, because of its small dimensions, it dries right through at the first touch of the sun.

The ground is equally dry in the vine. yard; but there is shade under the branches 


\section{The Life of the Weevil}

and the generous cigar is thick enough to retain in its central part, far better than the slender barrel does, a little of the moisture indispensable to the grub. In respect of prolonged abstinence, the Vine-Weevil cannot be compared with the barrel-maker; still less can the Poplar-Weevil. For this last, more often than otherwise, there is no danger from drought, despite the smallness of the cylinder, a sorry rat's-tail. This roll usually falls by the side of a ditch, on the moist soil of the meadows. The exploiter of the alder is hardly in danger either: at the foot of her tree, a lover of the trickling brooks, she finds the coolness needed to keep her food-cylinder in good condition. But, when she exploits the hazel-bush, I do not know what conditions help her out of her difficulty.

Lately the newspapers, which noisily echo every piece of absurdity, have been making a certain fuss about the gastric feats of a few poor devils who, to earn their bread, have fasted for thirty or forty days. As in most stunts, admirers were found, ready to encourage those wretched competitions. 


\section{Other Leaf-Rollers}

Now here is something far better, ye snobbish upholders of abstinence! A trivial beastie, not celebrated by the newspapers, a grub born the day before yesterday, takes a few mouthfuls; then, finding its victuals too dry, it eats no more for four months or longer. And this is not the result of sickly languor: the creature fasts in spite of the extreme appetite of youth, when, more than ever, the stomach demands a copious diet. The Rotifer, ${ }^{1}$ which for a whole season lies lifeless and desiccated in the mosses of its home, begins to whirl round again when placed in a drop of water. The grub of the Attelabus, lying near to death for four or five months, recovers its liveliness and eats like a glutton if I moisten its bread for it. What can life be, capable of such intermissions?

1 Or Wheel Animalcule.-Translator's Note. 


\section{CHAPTER $\mathrm{X}$}

THE SLOE-WEEVIL

TO less skilled than the Vine and Poplar1 Weevils in the art of leaf-rolling, the Attelabus and the Apoderus have shown us that, in spite of a dissimilar equipment, the industry may remain the same; they have proved that similarity of aptitude is compatible with diversity of organization. Conversely, different trades may be followed with the same tools; identity of form does not imply equivalence of instinct.

Who tells us this? Who puts forward this subversive proposition? The SloeWeevil (Rliynchites auratus, Scop.) has the audacity to do so.

Rivalling the exploiters of the vine and poplar in metallic lustre, she possesses, exactly as they do, a curved awl which one would say was meant for puncturing the stalk of a leaf and then fastening the edges of the rolled portion; her figure is short and squat, 196 


\section{The Sloe-Weevil}

adapted, so it seems to me, to working in the narrow crease of a fold; she has spiked sandals which give her a firm hold on slippery surfaces. Any one acquainted with the cigar-makers has but to see her to call her straightway by the same generic name. The nomenclators have made no mistake; they are unanimous in styling her a Rhynchites. Judging the trade by the worker's looks, we do not hesitate: we set down this third Rhynchites as a rival of the others, we class her in the leaf-rollers' guild.

Well, in this case, we are thoroughly deceived by outward appearances; we are taken in by an identity of structure. In her habits, the Rhynchites of the Sloe has nothing in common with the two with whom she is associated by her classification, which is based solely on the peculiarities of her form. What is more, until she is seen at work, no one would suspect her calling. She exploits the fruit of the sloe exclusively; her grub's ration is the tiny kernel and its lodging the small stone of the sloe.

So, unskilled in the trade of her fellows, without any change in her tools, the kinswoman of the cigar-makers becomes a driller 


\section{The Life of the Weevil}

of caskets; with the same bodkin that serves her relatives for fastening the last layer of a leaf-roll, she hollows a little cup in the surface of a shell hard as ivory. The tool that is able to roll a flexible sheet now wears away the invincible and works like a digger's pick-axe. And stranger still: when it has finished its arduous piece of carving, it sets up above the egg a little miracle whose exquisite delicacy we shall have occasion to admire.

The grub amazes me no less. It changes its diet. When a denizen of the vine and the poplar, it eats a leaf; when a denizen of the sloe, it takes to starchy food. It changes its means of liberation. When they have attained their full growth and the moment comes for them to go underground, the first two have nothing in front of them but a yielding obstacle, the surface layer of the leafy sheath, softened and wasted by decay; the third, like the Nut-weevil, has to pierce a wall of exceptional strength.

What singular contrasts might we not discover in facts of this kind, if we were better-acquainted with the habits of the Rhynchites group? A fourth example is 


\section{The Sloe-Weevil}

familiar to me (R. Bacchus, LiN.). Identical in shape with the manufacturers of cigars and the exploiters of fruit-stones, worthy, indeed, in all respects of the name of Rhynchites, what does this Weevil do? Does she roll leaves? No. Does she install her grub in the casket of a kernel? No.

Her trade is a very simple one, for her method is confined to inserting her eggs, here, there and everywhere, in the still green flesh of the apricot. Here there is no difficulty to overcome and consequently no art to be displayed by either mother or grub. The rostrum sinks into a material which offers but a slight resistance; the egg is let down to the bottom of the wound; and that is all. The establishment of the family is a most summary proceeding; it reminds us of the practice of the Larini.

The grub, for its part, has no need for talents of any sort. What would it do with them? It feeds on the pulp of the fruit, which soon falls to the ground and is reduced to a jelly. Life is easy in these liquescent surroundings; the infant is bathed in fermenting pap. When the time comes for it to take refuge in the subsoil, the jam-sodden 


\section{The Life of the Weevil}

grub has no veil to tear, no wall to break through: the flesh of the apricot has become a pinch of brown dust.

In the old days, the Anthidia, ${ }^{1}$ partly weavers of cotton, partly kneaders of resin, set me a difficult problem. Later came the Dung-Beetles of the pampas, the Phanæi, ${ }^{2}$ some preparing, as preserved foodstuff, cakes of Cow-dung modelled in the shape of a pear, others sausage-meat kept fresh in clay jars. Both suggested the same difficulty: can habits and industries which have no mutual connection be explained as soon as we accept a common origin for these different manufacturers, who moreover are so much alike in conformation? The question crops up again, more urgently, with the four Rhynchites.

That the influence of environment may, to some extent, have caused external modifications; that the light may have accentuated the colouring; that the quantity of the food may have brought about some small varia-

1 For these Cotten-bees and Resin-bees, cf. Bramble-bees and Others, by J. Henri Fabre, translated by Alexander Teixeira de Mattos: chaps. ix. and x.-Translator's Note.

2 Cf. The Glow-Worm and Other Beetles: chaps. ix. and x.-Translator's Note. 


\section{The Sloe-Weevil}

tion in size; that a warm or cold climate may have thinned or thickened the fur: all these changes and many others besides I willingly concede, if that will give any one any pleasure; but, for pity's sake, let us take higher ground than this, do not let us reduce the world of the living to a collection of digestive tubes, an assortment of bellies that fill and empty themselves.

Let us reflect upon the masterly touch that sets the whole animal machine in motion; let us question the instincts, the controllers of form; let us remember that glorious expression of the ancients, mens agitat molem; and we shall understand the inextricable difficulty that besets the theorists when they wish to explain how it is that of four insects, as much alike in shape as so many drops of water, two roll leaves, another carves fruitstones and the fourth profits by the pulp of a rotten fruit.

If they are affiliated to one another, if they are indeed related, as their so stronglymarked family-resemblance would seem to affirm, which of them was the first of the line? Could it be the leaf-roller?

No one, unless he be content with idle $20 I$ 


\section{The Life of the Weevil}

fancies, will admit that the cigar-roller can have tired of her cylinder one day and proceeded, as a crazy innovator, to make a hole in the casket of a fruit-stone. Such dissimilar industries do not suggest mutual connection. The first leaf-rollers, never knowing any lack of leaves, may perhaps have gone from one tree to others more or less like it; but to give up the art of leafrolling, so easy to acquire, and to become, when nothing compelled them to, strenuous nibblers of hard wood: that would have been idiotic. No acceptable reason would explain the desertion of the original trade. Such follies are unknown in the insect world.

The exploiter of the sloe refuses in her turn to acknowledge herself as inspiring the cigar-maker :

"What, I!" she says, "I, give up my little blue plum, so savoury in its tartness! I, a chaser of goblets, abandon my chisel and, in a moment of madness, become a folder of leaves! What do you take me for? My grub dotes on the floury kernel; confronted with any other fare, above all with the meagre, tasteless roll of my colleague of the poplar, it would let itself die of hunger. So 


\section{The Sloe-Weevil}

long as sloes or kindred fruits have existed, my race, thriving upon them, has never committed the folly of forsaking them in favour of a leaf. So long as they exist, we shall remain faithful to them; and, if ever they fail us, we shall perish to the last grub."

The lover of the apricot is no less positive. She, who is so easy to establish in soft pulp, has taken good care not to advise her children to undertake the laborious task of perforating a shell or rolling a leaf into a cigar. According to the locality and the abundance of the fruit, her boldest innovation has been to pass from the apricot to the plum, the peach, or even the cherry. But how are we to admit that these lovers of fruit-pulp, well satisfied with their rich living, which has always been possible, in the old days and to-day alike, can ever have risked leaving the soft for the hard, the juicy for the dry, the easy for the difficult?

None of these four is the head of the line. Is the common ancestor then an unknown species, dumped down, perhaps, in the schistfoliations whose venerable archives we began by consulting? Even if he were there, we should be none the wiser. The library of the 


\section{The Life of the Weevil}

stones preserves the forms but not the instincts; it says nothing of industries, because, let us repeat and again repeat, the insect's tool tells us nothing of its trade. With the same rostrum the Weevil may follow very different callings.

What the ancestor of the Rhynchites did we do not know and have no hope of ever knowing. The theorists, therefore, take their stand only on the vague and slippery ground of suppositions:

"Let us admit," they say, "let us imagine that ... it might be that ..." and so forth.

My dearly-beloved theorists, this is a most convenient means of arriving at any conclusion we like. With a bunch of nicelyselected hypotheses, I will undertake, though no subtle logician, to prove to you that white is black and that darkness is light.

I am too fond of tangible, indisputable truths; I will not follow you in your sophistical suppositions. I want genuine facts, well-observed, scrupulously-tested facts. Now what can you tell us of the genesis of the instincts? Nothing and again nothing and always nothing. 


\section{The Sloe-Weevil}

You think that you have raised a monument of Cyclopæan blocks and all that you have built is a house of cards which tumbles to pieces before the breath of reality. The real Rhynchites - not the imaginary one, but the insect which any one can observe and question at will-ventures to tell you so, in her artless sincerity.

She tells you:

"My manufactures, which are so contrary, cannot be derived one from another. Our talents are not the legacy of a common ancestress, for, to leave us such a heritage, the original initiator would have had to be versed at one and the same time in arts which are mutually incompatible: that of leaf-rolling, that of piercing fruit-stones and that of jammaking, to say nothing of the rest, which you don't yet know. If she was not capable of doing everything, she must, at least, in course of time, have given up a first trade and learnt a second, then a third, then a host of others, the knowledge of which is reserved for future observers. Well, to practise several industries at the same time, or even, from specializing in one department, to begin specializing in some other, quite different 


\section{The Life of the Weevil}

department: on my word as a Rhynchites, all this would seem madness to an animal."

Thus speaks the Weevil. Let me complete her statement. As the instincts of the three industrial guilds whose history is here related cannot in any way be referred to a common origin, the corresponding Rhynchites, despite their extreme similarity of structure, cannot be ramifications of the same stock. Each race is an independent medal, struck from a special die in the workshop of forms and aptitudes. What will it be then when dissimilarity of form is added to dissimilarity of instincts?

But enough of philosophizing. Let us make the closer acquaintance of the SloeWeevil. At the end of July, fattened to a nicety, the grub leaves its plum-stone and descends into the ground. With its back and forehead it presses back the surrounding dust and makes itself a spherical recess, slightly reinforced with a glue furnished by the builder, to prevent the earth from falling in. Similar preparations for nymphosis and hibernation are made by the Vine-weevil and the Poplar-weevil; but these are more forward in their development. Before Septem206 


\section{The Sloe-Weevil}

ber is over, most of them have achieved the adult form. I see them glittering in the sand of my jars like living nuggets. These golden globules foresee the rapidly approaching winter: as a rule they do not stir from their underground quarters. However, enticed by the hot sunlight, the last of the year, a few Poplar-weevils come up into the open air to see what the weather is like. At the first breath of the north wind, these venturesome ones will take refuge under the strips of dead bark; perhaps they will even perish.

The guest of the sloe is not in such a hurry. Autumn is drawing to a close; and my buried captives are still in the larval state. What matters this delay? They will all be ready when the beloved bush is covered with blossom. By May, in point of fact, the insect abounds on the sloes.

This is the time of careless revelry. The fruit is still too small, with its stone not set and its kernel a transparent jelly; it would not suit the grub, but it makes a feast for the adult, who, with an imperceptible movement, without any twisting of the boring-tool, sinks her drill into the pulp, drives it half- 


\section{The Life of the Weevil}

way down, holds it there motionless and drinks ecstatically. The juice of the sloe pours over the edge of the well.

This affection for the sour sloe is not exclusive. In my breeding-jars, even when the regulation fruit is there, Rhynchites auratus very readily accepts the green cherry and also the orchard plum, as yet hardly the size of an olive. She refuses absolutely, though they are as round and as small as sloes, the fruits of the mahaleb cherry, or Sainte-Lucie cherry, a wilding frequent in the thickets of the neighbourhood. She finds their drug-like flavour repellent.

When the egg is at stake, I cannot induce the mother to accept the cultivated plum. In time of dearth, the ordinary cherry seems to be less repugnant. Whereas the mother's stomach is satisfied with any sort of astringent pulp, the grub's clamours for a sweet kernel in a small casket which does not offer too much resistance. That of the cherry, seasoned with prussic acid and rather bitter, is accepted only with hesitation; that of the plum, contained in a stone whose strong walls would oppose too great an obstacle first to the entry and then to the exit of the grub, 


\section{The Sloe-Weevil}

is absolutely disdained. Therefore the pregnant mother, thoroughly versed in her household affairs, refuses for her family any stone fruit other than the sloe.

Let us watch her at work. During the first fortnight of June, the egg-laying is in full swing. At this period the sloes begin to assume a purple hue. They are hard, about as large as a pea, which is not far from their final size. The stone is woody and resists the knife; the kernel has acquired consistency.

The fruits attacked show two kinds of pit, turned brown by the decayed tissues. Some, the more numerous, are shallow funnels nearly always filled up with a drop of hardened gum. At these points the insect has simply made a meal and has not gone deeper than about half the thickness of the pulpy layer. Later, the exudations from the wound have filled the cavity with a gummy plug.

The other cavities, which are wider and form irregular polygons, penetrate to the stone. The opening measures nearly four millimetres $^{1}$; and the walls, instead of slant-

1 .156 inch.-Translator's Note. 


\section{The Life of the Weevil}

ing like those of the food-pits, rise vertically from the exposed stone. Let us note yet another detail whose importance we shall see presently: it is rare to find any gum in them, though the other cavities usually contain it. These pits, which are free from obstruction, are family establishments. I count two, three, four on the same sloe; sometimes only one. Very often they are accompanied, where the Weevil has fed, by funnel-shaped surface erosions.

The larger pits descending to the stone form a sort of irregular crater, in the centre of which there is always a little cone of brown pulp. Not infrequently the magnifying-glass reveals a fine perforation at the top of this central cone; at other times the orifice is closed, but in a careless fashion, which makes one suspect a connection with the depths below.

Cut this cone down the axis. At its base is a tiny hemispherical cup hollowed in the thickness of the stone. Here, on a bed of fine dust due to the work of erosion, lies a yellow egg, oval and about a millimetre ${ }^{1}$ long. Above the egg, like a protecting roof,

1 About $1 / 25$ inch.-Translator's Note. 


\section{The Sloe-Weevil}

rises the cone of brown pulp, pierced throughout its length by a fine channel, which is sometimes free and sometimes half obstructed.

The structure of the work tells us how the operation is conducted. In the fleshy layer of the sloe the mother, eating the substance, or discarding it if there be more than her appetite calls for, first makes a pit with perpendicular walls and lays a suitable surface of the stone absolutely bare. Then, in the centre of this area, she chases with her graver a little cup sinking half-way through the thickness of the shell. Here, on a soft bed of raspings, the egg is laid. Lastly, as a defensive device, the mother erects above the cup and its contents a pointed roof, a cone of pulp obtained from the walls of the pit.

The insect works very well in captivity, if given plenty of space, sunlight and a twig covered with sloes. It is easy to watch the proceedings of the egg-laying mother; but the result of diligent observation amounts to very little.

Almost the whole day, the mother remains clinging to one spot on the fruit, motionless, 


\section{The Life of the Weevil}

with her rostrum driven into the pulp. As a rule, there is no movement on her part, nothing to betray any effort.

From time to time a male visits her, climbs on her back, throws his legs around her and, himself swaying from side to side, rocks her very gently to and fro. Without permitting herself to be diverted from her serious labours, the female thus embraced passively yields to the rolling motion. Perhaps it is a means of whiling away the long hours needed for establishing an egg.

To see more than this is very difficult. The rostrum does its work in the hidden seclusion of the pulp and, as the pit opens and widens, the digger covers it with the fore-part of her body. The hollow is ready. The mother withdraws and turns round. For a moment I catch a glimpse of the bare stone at the bottom of the crater, with a tiny cup in the centre of the denuded area. As soon as the egg is laid in this cup, the insect turns round again and nothing more is visible until the work is completed.

How does the pregnant mother contrive to raise above the egg a protective heap, a cone, an obelisk somewhat irregular in 


\section{The Sloe-Weevil}

shape, but very curious with its narrow ventilating-shaft? Above all, how does she manage to make this communicating passage in the soft mass? These are details which we can scarcely hope to detect, so discreetly does the insect work. We must be content to know that the rostrum alone, without the aid of the legs, digs the crater and erects the central cone.

In the heat of June, less than a week is enough for the hatching. By good fortune, solicited, so far as that goes, by attempts that come near to exhausting my small stock of patience, I witness an interesting sight. I have a new-born grub before my eyes. It has just cast the skin of the egg; it is very busily wriggling in its powdery cup. Why so much excitement? For this reason: to reach the kernel, its ration, the tiny creature has to finish the pit and turn it into an entrancewindow.

A stupendous task for a speck of albumen. But this feeble speck boasts a set of carpenter's tools; its mandibles, a pair of fine chisels, received the necessary temper while their owner was still in the egg. The grub sets to work immediately. By the 


\section{The Life of the Weevil}

following day, through a tiny aperture which would hardly admit the point of a fair-sized needle, it has entered into the promised land and is in possession of the kernel.

Another stroke of luck partly tells me the use of the central cone pierced chimneyfashion. The mother, while sinking the pit in the flesh of the sloe, drinks the juices that ooze out and eats the pulp. This is the most direct manner of getting rid of the refuse without interrupting her work. When she is digging in the surface of the stone, the cup intended to receive the egg, she leaves in place the fine dust resulting from her labours, an excellent material as bedding for the egg but useless as food.

And what does the maggot in its turn do with its sawdust as it deepens the pit in order to reach the kernel? To scatter the rubbish round about is impossible: there is no room; to put it away in its stomach is even less feasible: it cannot make its first mouthfuls of this dry flour while waiting for the milkfood of a kernel.

The new-born grub has a better method. With a few heaves of its back, it thrusts the litter of rubbish outside, through the 


\section{The Sloe-Weevil}

chimney in the cone. I have indeed caught sight of a white, powdery speck at the top of the central cone. This tunnelled cone therefore is a lift which carries away the rubbish of the excavation.

But the use of the curious building cannot be limited to this: the ever thrifty insect has not gone to the pains of building a tall, hollow obelisk with the sole object of preparing a thoroughfare for the atoms of dust that hamper the grub in its labours. The same result could be obtained with less trouble; and the Weevil is too sensible to construct the complex when the single would suffice. Let us look at things more closely.

Evidently the egg, laid in a cup on the surface of the stone, needs a protecting roof. Moreover, the grub, which will presently be working at the bottom of its cup to reach the kernel, will require a refuse-shoot in its restricted quarters. A small, shallow dome, with a window to get rid of the sweepings, would, it seems, fulfil all the requisite conditions. Then why the luxury of this pyramidal chimney which rises to the topmost level of the pit, as a cone in eruption rises in the centre of a volcanic crater? 


\section{The Life of the Weevil}

The craters in the sloes have their lava, that is, their flow of gum, which trickles from the various points injured and then hardens into blocks. This flood stops up every hole at which the insect has merely fed. The large pits with the central cones, on the other hand, have no gum or show only a few scanty drops of it on their walls.

The mother, it is obvious, has taken certain precautions to defend the home of the egg against the inroads of the gum. In the first place, she has enlarged the cavity to keep the egg at a due distance from the treacherous wall oozing with viscidity; she has moreover dug the pulp down to the stone and has thoroughly stripped a perfectly clean surface from which nothing dangerous can now exude.

This is not yet enough: though distant and rising perpendicularly from the stripped area, the walls of the pit still give cause for alarm. In some sloes under certain conditions, they will perhaps yield a superabundance of gum. The only means of averting the danger is to raise above the egg a barricade as high as the brink of the crater and capable of arresting the flow. This is the reason for 216 


\section{The Sloe-Weevil}

the central cone. If there is a copious eruption, the gum will fill the ringed space, but at least it will not cover the spot where the egg lies. The tall, insubmersible obelisk is therefore a most ingeniously-contrived defensive structure.

This obelisk is hollow along its axis. We have seen it serving as a lift for the rubbish which the young grub throws out when deepening its natal basin and converting it into a passage which gives access to the kernel. But this is a very secondary function; it has another of greater importance.

Every egg breathes. In its cup with the sawdust mattress, the Weevil's egg needs a supply of air, a very moderate supply, no doubt, but it must have some. Through the passage in its conical roof the air reaches it and is renewed, even if bad luck has filled the crater with gum.

Every living creature breathes. The maggot has entered the stone of the fruit by making an opening such as our finest drills could not equal for precision. It is now in a sealed casket, an air-tight barrel, tarred, moreover, with gummy pulp. Yet it must have air, even more than the egg. 


\section{The Life of the Weevil}

Well, ventilation is effected by the shaft which the grub has driven through the thickness of the stone. However tiny the airhole, it is big enough provided it be not clogged. There is no need to fear anything of the sort, even with an excess of gum. Above the ventilator rises the defensive cone, continuing, by means of its tunnel, the communication with the outer world.

I wanted to know how anchorites more vigorous than the hermit of the sloe would behave in an exceedingly limited and renewable atmosphere. I must have them in the period of repose which precedes the metamorphosis. The insect has then completed its growth; it is no longer feeding; it is almost inert. It is living as cheaply as it can and may be compared with a germinating seed. Its need of air is reduced to the lowest possible limit.

Indifferent as to choice, I use what I have within reach and first of all the larvæ of the Brachycerus, the Weevil that feeds on garlic. A week ago they abandoned their cloves and went down into the earth, where, motionless in their hollows, they are making ready for the transformation. I place six of them in 218 


\section{The Sloe-Weevil}

a glass tube, sealed at one end by the blowpipe. I divide them one from the other by means of cork partitions, so as to allow each a cell comparable in capacity with the natural lodging. Thus stocked, the tube receives a first-rate cork covered with a layer of sealingwax. It is absolutely closed. No gaseous exchanges are possible between the inside and the outside; and each larva is strictly limited to the small quantity of atmosphere which I have meted out to it approximately, according to the capacity of the underground cells.

Similar tubes are prepared, some with Cetonia-grubs taken from the shells in which they were awaiting metamorphosis and others with nymphs of the same species. What will become of these various prisoners, whose life is latent, suspended, demanding a minimum of ventilation?

The sight that greets my eyes a fortnight later is conclusive. My tubes contain only a horrible mess of corpses. Evaporation was impossible; no fresh air came to cleanse the premises and vivify the larvæ and nymphs; and all have perished, all have become putrid.

The casket of the sloe, despite its air-tight condition, is not so close a receptacle as my 


\section{The Life of the Weevil}

glass prisons. Gaseous exchanges are effected, since the kernel, itself a living body, continues to thrive. But what suffices to maintain the life of a seed must be insuffcient for the much more active life of the insect. The larva of the Weevil, during the few weeks which it spends nibbling its kernel, would thus be in great jeopardy if it had no other resources for breathing than the air in the sloe-stone, so limited in quantity and so scantily renewed.

Everything seems to prove that if the airhole, the work of its chisel, were to be plugged with a drop of gum, the recluse would perish, or at least drag out a languishing existence and would be incapable of migrating underground at the proper time. This suspicion is worth confirming.

I therefore prepare a handful of sloes; I myself bring about what would have happened naturally but for the mother's precautions. I deluge the crater and its central cone with a drop of thick solution of gum arabic. My sticky preparation takes the place of the product of the sloe-bush. The drop hardens; I add others until the top of the cone disappears in the thickness of the 


\section{The Sloe-Weevil}

varnish. As for the rest of the fruit, I leave it as it was.

This done, let us wait, but leave the sloes in the open air, as they are, on the bush. There the gummy concretions will not grow soft-which would not fail to happen in a glass jar-merely by means of the moisture supplied by the fruits themselves.

By the end of July, the sloes left in their natural state give me the first emigrants; the exodus goes on through part of August. The means of exit is a round hole, very cleanly cut, similar to that made by the Nutweevil. Just like the grub of the lastnamed, the emigrant passes itself through the draw-plate and releases itself by a feat of gymnastics in which it dilates the part of the body already extracted with the humours forced out of the part still imprisoned.

The exit-door is sometimes one with the narrow entrance; more often it is beside it; but it is never, absolutely never, outside the bare space that forms the bottom of the crater. The grub seems to loathe finding the soft pulp of the sloe in front of its mandibles. Admirably adapted for chiselling hard wood, the tool would perhaps become 


\section{The Life of the Weevil}

clogged in a sticky mess. This needs a spoon to remove it, not a gouge. At all events, the exit is always made at some point of the floor thoroughly cleaned by the mother, where there is neither gum nor fleshy pulp to hamper the proper working of the tool.

What is happening at the same time with the gummy sloes? Nothing whatever. I wait a month: nothing yet. I wait two, three, four months: nothing, still nothing. Not a grub comes out of my prepared sloes. At last, in December, I decide to see what has been going on inside. I crack the stones whose air-holes I have blocked with gum.

Most of them contain a dead maggot, which has dried up while quite young. Some hide a live larva, well developed, but lacking in strength. You can see that the creature has suffered not from want of food, for the kernel is almost entirely consumed, but from another unsatisfied need. Lastly, a small number show me a live grub and an exit-hole made in the regular manner. These lucky ones, immured by the gum perhaps when they were already full-grown, had the strength to perforate the casket; but, finding on top of the wood the hateful varnish, which is the 


\section{The Sloe-Weevil}

result of my perfidy, they obstinately refused to bore any farther. The gummy barrier stopped them short; and it is not their habit to seek their freedom in another direction. Away from the bare floor, the bottom of the crater, they would infallibly come upon the pulp, which is no less detestable than the gum. In short, of the collection of larvæ subjected to my stratagems, not one has thriven; the sealing with gum has been fatal to them.

This result puts an end to my hesitations: the cone set up in the centre of the pit is necessary to the existence of the grub seques. tered in the stone. Its tunnel is a ventilating-shaft.

Each species certainly possesses its peculiar method of maintaining a connection with the outside world, when the larva lives under conditions in which the renewal of the air would be too difficult or even impossible if no precautions were taken. Generally, a fissure, a corridor, more or less unobstructed and the usual work of the grub, is enough to ventilate the dwelling. Sometimes it is the mother herself who sees to these hygienic requirements; and then the method 


\section{The Life of the Weevil}

employed is strikingly ingenious. While on this subject, let us recall the wonderful devices of the Dung-Beetles.

The Sacred Beetle models her grub's loaf in the form of a pear; the Spanish Copris ${ }^{1}$ shapes it like an egg. It is compact, homogeneous and as air-tight as stucco-work. To breathe in these lodgings would unquestionably be a very difficult thing; but the danger is provided against. Look at the small end of the pear and the top of the ovoid. After ever so little reflection, you will be seized with surprise and admiration.

There-and there only-you will see, not the air-tight paste of the rest of the work, but a stringy plug, a disk of coarse velvet bristling with tiny fibres, a round piece of loosely-made felt through which the gaseous exchanges can be effected. A filter takes the place of the solid material. The mere appearance is enough to tell us the function of this part. If doubts occurred to our minds, here is something to dispel them: I cover the fibrous expanse with several coats of varnish; I deprive the filter of its porous-

1 Cf. The Sacred Beetle and Others: chaps. ix. and x.-Translator's Note. 


\section{The Sloe-Weevil}

ness, without interfering with any other part. Now let us see what happens. When the time comes for the emergence, with the first autumn rains, let us break open the pills. They contain nothing but shrivelled corpses.

An egg is killed if you varnish it: when placed under the sitting Hen it remains a lifeless pebble. The chicken has died in the germ. So perish the Sacred Beetle, the Copris and the rest when we varnish the circular disk of felt which acts as a ventilator.

This method of the porous plug is recognized as being so efficacious that it is in general use among the pill-makers of the remotest regions. The Splendid Phanæus and Bolbites onitoides, both from Buenos Aires, ${ }^{1}$ employ it as zealously as the DungBeetles of Provence.

One of the dwellers in the pampas uses another process, prescribed by the material which she manipulates. This is Phancus Milon, a ceramic artist and meat-packer. With very fine clay she fashions a gourd in the middle of which she places a round meat-

${ }^{1}$ For both these Beetles and also for the next insect mentioned in the text, Phancus Milon, cf. The Gloryworm and Other Beetles: chap. ix.-Translator's Note. 


\section{The Life of the Weevil}

pie made from the sanies of a corpse. The grub for which these victuals are intended hatches in an upper story, separated from the larder by a clay partition.

How will this grub breathe, first in its cell upstairs and then in the lower room, when it has perforated the floor and reached the cold pasty? The house is a piece of pottery, an earthenware jar whose wall sometimes measures a finger's-breadth in thickness. Air cannot possibly pass through such a casing. The mother, who knew this, made arrangements accordingly. Along the gourd's neck she contrived a narrow passage through which a flow of air is possible. Without resorting to obstruction by means of varnish or anything else, we see quite plainly that this minute tunnel is a ventilating-shaft.

Exposed on her fruit to the danger from the gum, the Weevil excels the meat-packer of the pampas in her delicate precautions. Over the spot where the egg lies, she raises an obelisk, the equivalent of the gourd's neck in the work of the Phanæus; to give the germ air, she leaves the axis of the nipple hollow, as does the potter. In either case, 


\section{The Sloe-Weevil}

the new-born grub has a tough job to begin with: in the one it chisels the fruit-stone; in the other it pierces the earthenware partition. And now both have reached their goal: the first its kernel, the second its meatpie. Behind them they have left a round port-hole which continues the tunnel made by the mother. Thus communication between the inside of the establishment and the outer atmosphere is assured.

The comparison cannot be carried farther, so greatly does the ingenuity of the Rhynchites, in danger of being stifled by the gum, surpass that of the other Beetle, who is perfectly safe in his clay pot. The Weevil has to reckon with the terrible exudations which threaten to submerge and stifle her larva. The mother, therefore, in the first place, builds up the defensive cone, the ventilating-shaft, to a height which the gummy flood will not reach; then, around this rampart of fruit-pulp, she makes a wide moat which keeps at a distance the wall sweating the dangerous substance. If the eruption is too violent, the viscous fluid will collect in the crater without imperilling the breathing-hole. 


\section{The Life of the Weevil}

If the Rhynchites and her competitors in means of defence against the dangers of asphyxia have taught themselves their trade by degrees, by passing from an unsuccessful to another, more satisfactory method; if they are really the creatures of their achievements, do not let us hesitate, though we deal a blow to our self-conceit: let us recognize them as engineers capable of teaching a lesson to our own graduates; let us acclaim the microcephalous Weevil as a powerful thinker, a wonderful inventor.

You dare not go to that length; you prefer to appeal to the hazards of chance. But what a wretched resource is chance when we are considering such rational contrivances! As well throw the letters of the alphabet up in the air and expect them to form a given line of a poem as they fall!

Instead of bamboozling our minds with such tortuous conceptions, how much simpler and above all how much more truthful to say: "Matter is governed by a sovereign order."

This is what the Sloe-weevil, in her humble way, tells us. 


\section{CHAPTER XI}

THE PEA-WEEVIL: THE EGGS

MAN holds the pea in high esteem. 1 Ever since the days of antiquity, he has tried, by devoting greater and greater attention to its cultivation, to make it produce larger, tenderer and sweeter varieties. The adaptable plant, gently entreated, has complied with his desires and has ended by giving us what the gardener's ambition aimed at obtaining. How far we moderns have progressed beyond the crop of the Varros ${ }^{1}$ and Columellas, ${ }^{2}$ how far, above all, beyond the original peas, beyond the wild seeds confided to the soil by the first man who thought of scraping the earth, may-

${ }^{1}$ Marcus Terentius Varro (B. C. I16-Circa B. C. 27), a famous Roman scholar, author of $D e$ Re rustica and for some time director of the public library.-Translator's Note.

${ }^{2}$ Lucius Junius Moderatus Columella ( $f$. Ist century A.D.), author of a work, $D e R_{e}$ rustica, bearing the same title as Varro's. - Translator's N'ote. 


\section{The Life of the Weevil}

be with a jaw-bone of the Cave-bear, ${ }^{3}$ whose mighty canine did duty as a ploughshare!

Where is this plant, the first source of the pea, in the world of spontaneous vegetation? Our regions possess nothing like it. Is it to be found elsewhere? On this point botany is silent, or replies only with vague probabilities.

For that matter, the same ignorance prevails on the subject of most of our edible plants. Whence comes wheat, the blessed grain that gives us bread? No one knows. Except in the fields tilled by man, you need not look for it in this country. You need not look for it abroad either. In the East, where agriculture had its birth, no botanist ever came across the sacred ear increasing of its own accord on ground not broken by the plough.

Barley, oats and rye, the turnip and the radish, the beet, the carrot, the pumpkin leave us in a like uncertainty: their origin is unknown, or at most suspected behind the

${ }^{3}$ A very large, prehistoric Bear (Ursus spelcous) whose remains are common in European caves, including those of England.-Translator's Note. 


\section{The Pea-Weevil: The Eggs}

impenetrable mist of the ages. Nature delivered them to us in the full vigour of things untamed, when they were of little value as food, as she nowadays offers us the wild blackberry and the sloe; she gave them to us in a rudimentary and incomplete state; and it was for our husbandry and ingenuity patiently to hoard the nutritive pulp, that earliest form of capital, with dividends always increasing in the most excellent bank of the tiller of the soil.

As storehouses of provisions, the cereal and the garden vegetable are, for the most part, the work of man. The founders of the species, a poor resource in their original condition, we borrowed as we found them from nature's green treasury; the improved race, rich in nourishing matter, is the result of our art.

But, if wheat, peas and the rest are indispensable to us, our care, in fair exchange, is absolutely necessary to their maintenance. Such as our needs have made them, incapable of resistance in the savage conflict of living things, these plants, if left to themselves, without cultivation, would rapidly disappear, despite the numerical immensity of their 


\section{The Life of the Weevil}

seeds, even as the silly Sheep would shortly disappear were there no sheepfolds.

They are our work, but not always our exclusive property. Wherever food is amassed, consumers flock from the four corners of the sky; they invite themselves to the copious feast; and, the richer the victuals, the greater their numbers. Man, who alone is capable of provoking agrarian luxuriance, becomes by this very fact the giver of an immense banquet whereat legions of guests take their places. By creating more palatable and more generous victuals, he willy-nilly summons to his granaries thousands and thousands of famished creatures against whose teeth his prohibitions battle in vain. The more he produces, the larger tribute he has to pay. Big crops and sumptuous hoards favour the insects, our rivals as consumers.

It is the prevailing law. Nature offers her mighty breast with equal zeal to all her children, to those who live by others' goods no less than to the producers. For us who plough and sow and reap, wearing ourselves out with toil, she ripens the wheat; she ripens it also for the little Corn-weevil, 


\section{The Pea-Weevil: The Eggs}

who, though exempted from the labour of the fields, will nevertheless settle in our granaries and with her pointed beak nibble the heap of corn, grain by grain, to the husk. For us who dig and weed and water, bent with fatigue and burnt by the heat of the day, nature swells the pea-pods; she swells them also for the Pea-weevil, who, doing no gardener's work, will all the same take her share of the crop at her own time, when the earth is joyful with the new life of spring.

Let us watch the actions of this zealous tax-collector, who levies her tithes in green peas. I, a well-meaning rate-payer, will let her have her way: it is precisely for her benefit that I have sown a few rows of the beloved plant in my enclosure. With no other invitation from me than this modest seed-plot, she arrives punctually in the course of May. She has learnt that in this stony soil, unfitted for market-gardening, peas are flourishing for the first time. And she has hastened thither to exercise her privileges as an entomological revenue-officer.

Whence does she come? It is impossible to say exactly. She has come from some refuge or other where she has spent the 


\section{The Life of the Weevil}

winter in a state of torpor. The planetree, which strips itself of its own initiative during the heat of summer, furnishes excellent shelters for homeless paupers under its patches of loose-hanging bark. I have often found our Pea-thief in one of these winter sanctuaries. Sheltered under the dead covering of the plane, or otherwise protected while the winter raged, she woke from her slumbers at the first kisses of a kindly sun. The almanack of the instincts has taught her; she knows as well as the gardener when the peas are in flower and she comes to her plant more or less from every direction, ambling at a slow pace, but swift in flight.

A small head, a slender snout, a dress of ashen grey sprinkled with brown, flat wingcases, a squat, thick-set figure, with two large black dots on the flat of the tail: there you have a rough sketch of my visitor. The van-guard arrives by the end of the first fortnight in May.

The Weevils settle on the flowers, which are like so many white Butterflies' wings: I see some installed at the foot of the upper petal, I see some hidden in the casket of the 


\section{The Pea-Weevil: The Eggs}

keel. Others, more numerous these, explore the blossoms and take possession of them. The laying-time has not yet come. It is a mild morning; the sun is hot without being oppressive. This is the moment for nuptial exploits and for raptures amid the splendour of the light. Life therefore is enjoyed for a little while. Couples form, soon part and soon come together again. When the heat grows too great, towards the middle of the day, each Jack and Jill retire into the shade, in a fold of the flower whose secret recesses they know so well. To-morrow they will resume the festival and the next day too, until the pod, splitting the sheath of its keel, appears outside, more and more swollen from day to day.

A few pregnant mothers, harder-pressed than the rest, confide their eggs to the growing pod, as it issues flat and tiny from its floral scabbard. These eggs laid prematurely, pushed out perhaps through the exigencies of an ovary which can wait no longer, seem to me in serious danger. The seed in which the grub is to make its home is as yet but a feeble granule, without substance and without floury contents. No 


\section{The Life of the Weevil}

Weevil-larva would ever find an adequate meal there, unless by biding its time until the seed ripened.

But is the grub, once hatched, capable of long fasting? It is doubtful. The little that I have seen tells me that the new-born larva begins eating with all speed and, if it cannot do so, dies. I therefore regard as lost the eggs laid upon immature pods. The prosperity of the race will hardly suffer, thanks to the Weevil's fertility. Moreover, we shall see presently with what reckless prodigality she scatters her germs, most of which are doomed to perish.

The bulk of the mother's work is finished by the end of May, when the pods begin to bulge with protuberances revealing the pressure of the peas, which have now attained their final size, or very nearly. I was anxious to see the Bruchus at work, in her quality of a Curculio, which is how she is classified. ${ }^{1}$ The other Weevils are Rhynchophorx, beak-wearers, armed with a rod that prepares the hollow in which the egg

1 The modern classification places the Pea- and Haricot-Weevils in a separate family, the Bruchidæ, whereas the family of the Curculionidx includes most of the other, or true, Weevils.-Translator's Note. 


\section{The Pea-Weevil: The Eggs}

is laid. Our friend possesses only a short snout, which does capitally for sipping a few sweet mouthfuls, but which is of no value as a boring-tool.

Therefore the method of installing the family is quite different. Here we see no ingenious preparations, such as the Balanini, the Larini and the Rhynchites showed us. Having no probe among her tools, the mother scatters her eggs in the open, with no protection against the heat of the sun or the inclemencies of the weather. Nothing could be simpler and nothing more dangerous to the germs, in the absence of a special constitution made to withstand the alternate trials of heat and cold, drought and wet.

In the mild sunshine of ten o'clock in the morning, the mother, with a jerky, capricious, unmethodical step, runs up and down the chosen pod, first on one and then on the other surface. She protrudes at every instant a short oviscapt, which swings right and left as though to scrape the skin. An egg follows and is abandoned as soon as laid.

A hasty touch of the oviscapt, first here, then there, on the green skin of the pea-pod; 


\section{The Life of the Weevil}

and that is all. The germ is left there, unprotected, right in the sun. Nor is any choice of site made, to assist the coming grub and shorten its quest when it has to make its way unaided into the larder. There are eggs placed on the swellings created by the peas; there are just as many in the barren dividing valleys. It is for the grub to take its bearings accordingly. In short, the Bruchus' eggs are laid anyhow, as though sown on the wing.

A more serious flaw: the number of eggs confided to one pod is not in proportion to that of the peas contained in it. Let us first realize that each grub needs a ration of one pea, an obligatory ration, amply sufficient for the welfare of one larva, but not big enough for several consumers, nor even for two. A pea for each grub, no more and no less, is the invariable rule.

Procreative economy would therefore demand that the mother, familiar with the pod which she has just explored, should, when emitting her germs, more or less limit their number to that of the peas which it contains. Now there is no limit. To a 


\section{The Pea-Weevil: The Eggs}

single ration the impetuous ovaries always offer a multiplicity of consumers.

My notes are unanimous on this point. The number of eggs laid on a pod always exceeds and often in a scandalous fashion the number of peas available. However scanty the food-wallet may be, the gruests are superabundant. Dividing the number of eggs perceived on a given pod by that of the peas inside it, I find from five to eight claimants for each pea; I find as many as ten; and there is nothing to tell me that the prodigality does not go farther still. Many are called, but few are chosen! Why all these supernumeraries, who are necessarily excluded from the banquet for want of space?

The eggs are a fairly bright amber-yellow, cylindrical in form, smooth and rounded at both ends. They are a millimetre long at most. ${ }^{1}$ Each of them is fixed to the pod by a thin network of threads of coagulated albumen. Neither the rain nor the wind can loosen their hold.

The mother often emits them two at a

1 1/25 inch.-Translator's Note. 


\section{The Life of the Weevil}

time, one above the other; often also the uppermost of the pair succeeds in hatching whereas the lower fades and perishes. What did this latter lack, to produce a grub? A sun-bath, perhaps, the gentle incubation of which the upper egg robs it. Whether through the effect of the untimely screen that overshadows it, or for some other reason, the elder of the eggs in a group of two rarely follows the normal course. It withers on the pod, dead before it has come to life.

There are exceptions to this premature end. Sometimes the twin eggs develop equally well; but these instances are so rare that the family of the Bruchus would be reduced by nearly one-half if the binary system were a fixed rule. To the detriment of the peas and to the Weevil's advantage there is one thing that lessens this destructive factor: the eggs are laid one by one and in separate places.

A recent hatching is marked by a whitish, winding little ribbon, which raises and fades the skin of the pod near the sloughed eggshell. It is the work of the new-born larva and is a subcutaneous tunnel along which the tiny creature wends its way in search 


\section{The Pea-Weevil: The Eggs}

of a point through which to penetrate. When it has found this spot, the grub, measuring hardly a millimetre and palebodied, with a black cap, pierces the outer wrapper and dives into the capacious sheath of the pod.

It reaches the peas and perches on the nearest. I watch it through the magnifyingglass, exploring its globe, its world. It sinks a well at right angles to the sphere. I see some which, half-way down, wriggle their tails to stimulate their efforts. After a short spell of work, the miner disappears and is at home.

The entrance-hole is minute, but is easily recognized at any time by its brown colouring against the pale-green or yellow-green background of the pea. It has no fixed site; we see it more or less anywhere on the surface of the pea, excepting generally on the lower half, that is to say, the hemisphere whose pole is formed by the base of the funicular cord.

It is precisely in this part that the germ is found which will not be consumed and will remain capable of developing into an embryo plant, in spite of the large hole made 
by the adult insect in leaving. Why is this portion left unscathed? What are the reasons that safeguard the germ of the exploited seed?

It goes without saying that the Bruchus does not consider the gardener. The pea is meant for it and none other. In refusing to take the few bites which would entail the death of the seed, it has no intention of reducing the damage. It abstains from other motives.

Remark that the peas touch at the sides, where they are pressed one against the other. The grub seeking the point of attack cannot move about at its ease. Remark also that the lower pole rests upon the umbilical excrescence and opposes to any attempt at boring difficulties which do not exist in the parts protected by the skin alone. It is even possible that this umbilicus, which is differently organized, contains special juices distasteful to the little larva.

This, beyond a doubt, is the secret of the peas exploited by the Bruchus and yet remaining fit to sprout. They are injured but not dead, because they are invaded in the free hemisphere, the part which is at 


\section{The Pea-Weevil: The Eggs}

the same time easier to enter and less easy to wound. Moreover, as the whole pea is too much for a single grub, the loss of substance is reduced to the piece preferred by the consumer; and this piece is not the essential part of the pea.

Given other conditions, with seeds either very small or exceedingly large, we should see the results changing entirely. In the first case, the germ would be gnawed like the remainder and would perish by the tooth of the too niggardly served grub; in the second case, the abundant food would allow of several guests. The common vetch and the broad bean, exploited in the absence of the pea, tell us something in this connection: the smaller seed, devoured all but the skin, is a ruin whose germination we may expect in vain; the larger, on the contrary, despite the Weevil's numerous cells, is still capable of sprouting.

Admitting that the number of eggs on the pod is always much greater than that of the peas contained and that, on the other hand, each pea is the exclusive property of one grub, we wonder what becomes of the surplus. Do these larvæ perish outside, 


\section{The Life of the Weevil}

when the more precocious have taken their places one by one in the leguminous larder? Do they succumb to the intolerant teeth of the early occupants? They do neither. Let us set forth the facts.

On all old peas, now dry, from which the adult Weevil has issued, leaving a gaping hole, the magnifying-glass reveals a varying number of fine, reddish-brown dots, perforated at the centre. What are these spots, of which I count five or six or even more on a single pea? There is no mistake possible: they are the entrance-points of so many grubs. Several workers have therefore penetrated into the seed; and of the whole gang only one has survived, waxed big and fat and attained the adult age. And the others? We shall see.

At the end of May and in June, during the laying-season, inspect the still green and tender peas. Nearly all the seeds invaded show us the multiple dots which we already observed on the dry peas abandoned by the Weevils. Does this actually mean an assembly of guests? Yes. Skin the aforesaid seeds, separate the seed-lobes, subdivide them if necessary. We discover several 


\section{The Pea-Weevil: The Eggs}

larvæ, very young, bent into a bow, fat and wriggling, each in a little round hollow in the heart of the victuals.

Peace and comfort seem to reign in the community. There is no quarrelling, no jealous competition among neighbours. The eating has begun, provisions are plentiful and the banqueters are separated from one another by partitions formed by the as yet untouched portions of the seed-lobes. With this isolation in separate cells, there is no fear of squabbles; the guests will not bite one another, by accident or intention. All the occupants enjoy the same rights of property, the same appetite and the same strength. What will be the end of the communal working?

I split some peas which I have found to be well-stocked and place them in a glass tube. I add others daily. This method keeps me informed of the boarders' progress. At first there is nothing special. Isolated in its narrow recess, each grub nibbles around itself and eats frugally and peacefully. It is still quite small; a speck of food surfeits it.

Nevertheless, a dish consisting of one pea cannot satisfy so large a number until the 


\section{The Life of the Weevil}

end. Famine threatens; all save one must die.

Soon indeed the aspect of things changes. One of the grubs, the one occupying the central position in the pea, grows faster than the others. He has hardly begun to be larger than his competitors when these cease to eat and refrain from digging any farther. They lie motionless and resigned; they die the gentle death which reaps unconscious lives. They disappear, wasted away to nothing. They were so tiny, the poor victims! Henceforth the whole pea belongs to the sole survivor. But what has happened, to produce this desolation around the privileged one? For lack of a relevant answer, I will propound a suggestion.

In the centre of the pea, more gently stewed than the rest by the sun's chemistry, may there not be an infant-pap, a pulp of a quality better-suited to the delicate organs of a grub? Here perhaps, stimulated by tender, highly flavoured and sweeter food, the stomach becomes more vigorous and fit to cope with food less easily digested. A baby is fed on milk before it receives the basin of broth and the bread of the able246 


\section{The Pea-Weevil: The Eggs}

bodied. Might not the central portion of the pea be the Weevil-grub's feeding-bottle?

Fired by one ambition and endowed with equal rights, all the occupants of the seed set out towards the delicious morsel. It is a laborious journey; and frequent halts are made in temporary recesses. The grubs rest; pending better things to come, they frugally crunch the ripe substance around them; they gnaw even more to open a way than to fill their stomachs.

At last one of the excavators, favoured by the direction taken, reaches the central dairy. It settles there and the thing is done: there is nothing for the rest but to die. How do they come to know that the place is taken? Do they hear their kinsman's mandibles striking against the wall of his cell? Can they feel the vibration of the nibbling at a distance? Something of the sort must happen, for from that moment they cease their attempts to burrow any farther. Without struggling with the lucky winner, without seeking to dislodge him, those beaten in the race allow themselves to die. I like this frank resignation on the part of the late arrivals. 


\section{CHAPTER XII}

THE PEA-WEEVIL: THE LARVA

A NOTHER condition, that of space, is $\mathbf{A}$ present as a factor. The Pea-weevil is the largest of our Bruchi. When she attains the adult age she requires a bigger lodging than is demanded by the other seeddestroyers. A pea provides her with a very adequate cell; nevertheless, cohabitation in twos would be impossible: there would be no room, even if the occupants accepted the discomfort. And so the inexorable need returns for reducing the numbers and, in the seed invaded, doing away with all the competitors save one.

On the other hand, the broad bean, which is almost as great a favourite of the Bruchus as the pea, is able to house a whole community. The grub that was but now a solitary becomes a cenobite. There is room for five or six more, without encroaching on the neighbours' domain. Moreover, each grub 248 


\section{The Pea-Weevil: The Larva}

finds infant-food within its reach, that is to say, the layer which, being at some distance from the surface, hardens slowly and retains the dainty juices for a greater length of time. This inner layer may be regarded as the crumb of an otherwise crusty loaf.

In the pea, which is a small sphere, it occupies the central part, a limited area which the grub has to reach or perish; in the bean, a generous muffin, it includes the large joint of the two flat seed-lobes. No matter where the big seed is tackled, each larva need but bore straight ahead and it quickly reaches the coveted food.

Then what happens? I add up the eggs adhering to a bean-pod, I count the seeds inside and, on comparing the two totals, I find that there is plenty of room for the whole family, at the rate of five or six to each bean. Here we have no surplus larvæ dying of starvation almost as soon as they leave the egg: all have their share of the ample portion, all live and prosper. The abundance of the provisions counterbalances the mother's extravagance.

If the Bruchus always adopted the broad bean as the establishment of her family, I 


\section{The Life of the Weevil}

could very well explain her exuberant emission of germs on a single pod: a rich supply of food, easily acquired, invites a large colony. The pea, on the other hand, puzzles me. What vagary makes the mother abandon her offspring to starvation on this insufficient legumen? Why so many boarders gathered around a seed which forms the ration of one alone?

It is not thus that matters are arranged in life's general balance-sheet. A certain foresight rules the ovaries and makes them adjust the number of eaters to the abundance or scarcity of the thing eaten. The Sacred Beetle, the Sphex-wasp, the Burying-beetle and the other manufacturers of prcserved provisions for the family set close limits to their fertility, because the soft loaves of their baking, the baskets containing their game and the contents of their sepulchral retting-vat are all obtained at the cost of laborious and of ten unproductive efforts.

The Bluebottle, on the contrary, heaps her eggs in bundles. Trusting in the inexhaustible wealth of a corpse, she lavishes her maggots without counting the number. At other times, the provision is obtained by 250 


\section{The Pea-Weevil: The Larva}

crafty brigandage, exposing the new-born offspring to a thousand fatal accidents. Then the mother makes up for the chances of destruction by an excessive outpouring of eggs. This is the case with the Oil-beetles, who, stealing the property of others under very parlous conditions, are for that reason endowed with prodigious fertility.

The Bruchus knows neither the fatigues of the hard worker, obliged to restrict her family, nor the woes of the parasite, obliged to go to the other extreme. Without costly researches, entirely at her ease, merely by strolling in the sun over her favourite plant, she can ensure an adequate provision for each of her children; she can do this and yet the mad creature takes it into her head to overpopulate the pea-pod, a niggardly baby-farm in which the great majority will die of starvation. This folly passes my understanding: it clashes so utterly with the usual perspicacity of the maternal instinct.

I am therefore inclined to believe that the pea was not the Bruchus' original share in the distribution of the earth's gifts. It must rather have been the bean, one seed of which is capable of entertaining half a dozen 


\section{The Life of the Weevil}

visitors and more. With a seed of this size, the startling disproportion between the number of the insect's eggs and the foodstuffs available disappears.

Besides, there is not a doubt that, of our various culinary acquisitions, the broad bean is the earliest in date. Its exceptional dimensions and its pleasant flavour have certainly attracted man's attention since the most remote times. It is a ready-made mouthful, of great value to the hungry tribe, which would have hastened to secure its increase by sowing it in the patch of garden beside the house, a hut of wattled branches plastered with mud. This was the begining of agriculture.

Travelling by long stages, with their waggons drawn by shaggy Oxen and rolling on solid wheels cut out of the trunks of trees, the emigrants from Central Asia brought to our uncultivated tracts first the bean, then the pea and finally the cereal, that eminent stand-by against hunger. They taught us the care of herds and the use of bronze, of which the first metal implements were made. Thus did the dawn of civilization rise over Europe. 


\section{The Pea-Weevil: The Larva}

With the bean did those ancient pioneers bring us, involuntarily, the insect which disputes its possession with us today? There is room for doubt; the Bruchus seems to be a native. I find her at least levying tribute on divers Leguminosæ of the country, spontaneous plants which have never tempted man's appetite. She abounds in particular on the great broad-leaved everlasting pea (Lathyrus latifolius), with its magnificent clusters of flowers and its long and handsome pods. Its seeds are not large, are much smaller than those of our peas; but, gnawed to the very skin, as they always are by their occupants, they are each sufficient to the welfare of its grub.

Note also their considerable number: I have counted more than twenty to the pod, a wealth unknown to the garden pea, even in its most prolific state. Thus the superb perennial is generally able, without much loss, to feed the family entrusted to its pod.

Where the everlasting pea is lacking, the Bruchus none the less continues her habitual flux of germs on another legumen, of similar flavour but incapable of nourishing all the grubs, as for instance on the broad-podded 


\section{The Life of the Weevil}

vetch (Vicia peregrina) or the common vetch $(V$. sativa). The number of eggs remains high even on these insufficient pods, because the original plant offered a copious provender, whether by the multiplicity or by the large size of the seeds. If the Bruchus is really a foreigner, we may accept the bean as her first victim; if the insect is a native, let us accept the everlasting pea.

Some time in the remote past the pea reached us, gathered at first in the same prehistoric garden-patch which already supplied the bean. Man found it a better food than the horse-bean, which is very much neglected to-day after doing such good service. The Weevil was of the same opinion and, without quite forgetting her broad bean and her everlasting pea, generally pitched her camp on the garden pea, which became more widely cultivated from century to century. Today we have to go shares: the Bruchus takes what she wants and lets us have her leavings.

The insect's prosperity, born of the abundance and quality of our products, from another point of view spells decadence. For the Weevil as for ourselves, progress in the matter of food and drink does not always 


\section{The Pea-Weevil: The Larva}

mean improvement. The race fares better by remaining frugal. On her horse-bean, on her everlasting pea, the Bruchus founded colonies in which the infant mortality was low. There was room for all. On the pea, a delectable sweetmeat, the greater part of the guests die of starvation. The rations are few and the claimants legion.

We will linger over this problem no longer. Let us enquire into the grub which has become the sole owner of the pea through the death of its brothers. It has had no part in that decease; chance has favoured it, that is all. In the centre of the pea, a luxurious solitude, it performs a grub's duty, the one and only duty of eating. It gnaws the walls around and enlarges its cell, which it always fills completely with its fair round belly. It is a plump and shapely creature, glistening with health. If I tease it, it turns lazily in its cell and wags its head. This is its way of complaining of my rudeness. Let us leave it in peace.

The anchorite thrives so well and so fast that, by the dog-days, it is already making ready for its coming liberation. The adult has not the necessary tools to open for her- 


\section{The Life of the Weevil}

self her way out of the pea, which is now quite hard. The larva knows of this future helplessness and provides against it with consummate art. With its strong jaws it bores an exit-shaft, absolutely circular, with very clean-cut sides. Our best ivory-carvers could produce nothing neater.

To prepare the door of escape in advance is not enough; we must also think of the tranquillity essential to the delicate work of the nymphosis. An intruder might enter through the open door and work mischief upon the defenceless nymph. This opening must therefore be kept shut. And how? Here is the device.

The grub boring the exit-hole eats the floury matter without leaving a single crumb. On reaching the skin of the seed, suddenly it stops short. This semitranslucent membrane is the screen protecting the chamber in which the metamorphosis takes place, the door that defends the cabin against ill-intentioned intruders. It is also the only obstacle which the adult will encounter at the time of moving. To lessen the difficulty of forcing it out, the grub takes the precaution of carving a groove of least resistance inside the 


\section{The Pea-Weevil: The Larva}

skin, all around the circumference. The perfect insect will only have to heave with its shoulders, to strike a blow or two with its head, in order to raise the lid and knock it off, like the lid of a box. The exit-hole shows through the transparent skin of the pea in the shape of a large circular spot, darkened by the obscurity within. What happens below cannot be seen, hidden as it is behind a sort of ground-glass window.

A pretty invention, this little port-hole, this barricade against the invader, this trapdoor lifted with a push of the hermit's shoulder when the time has come. Shall we give the Bruchus the credit of it? Could the ingenious insect imagine the enterprise, ponder a plan and work upon a scheme of its own devising? This would be a fine triumph for a Weevil's brain. Before deciding, let us hear what experiment has to tell us.

I skin some inhabited peas; I save them from drying too quickly by placing them in glass tubes. The grubs do as well here as in the intact peas. The preparations for the deliverance are made at the proper time.

If the miner acts on its own inspiration, 


\section{The Life of the Weevil}

if it ceases to prolong its shaft as soon as it perceives, by sounding it now and again, that the ceiling is thin enough, what ought to happen under the present conditions? Feeling that it is as near the surface as it wishes to be, the grub will stop boring; it will respect the last layer of the bare pea and will thus obtain the indispensable defensive screen.

Nothing of the kind takes place. The well is excavated entirely; its mouth is open to the outside, as wide, as carefully finished as though the skin of the pea were still protecting it. Reasons of safety have in no way modified the usual work. The foe can enter this open lodging; the grub gives the matter not a thought.

Nor has it this in mind when it refrains from boring right through the pea still clad in its skin. It stops suddenly, because it does not like the non-farinaceous skin. We remove the skins before making our peas into soup: they have no culinary value; they are not good. The larva of the Bruchus appears to be like ourselves: it hates the tough outside of the pea. Warned by the unpleasant taste, it stops at the skin; and this aversion 258 


\section{The Pea-Weevil: The Larva}

causes a little miracle. The insect has no logical sense of its own. It passively obeys a higher logic; it obeys, but is as unconscious of its art as crystals are when assembling their battalions of atoms in exquisite order.

Sooner or later, in August, dark circles form on the peas, always one to each seed, with no exception. These mark the exithatches. Most of them open in September. The lid, which looks as though cut out with a punch, comes off very neatly and falls, leaving the opening of the cell free. The Bruchus issues, freshly clad, in her final form.

The weather is delightful. Flowers abound, awakened by the showers; the emigrants from the peas visit them in autumnal revelry. Then, when the cold sets in, they take up their winter-quarters in some retreat or other. Others, quite as numerous, are less eager to quit the native seed. They stay there, motionless, all through the frosty season, sheltered behind the trap which they are careful not to touch. The door of the cell will not open on its hinges, that is to say, along its line of least resistance, until the hot weather returns. Then the laggards leave their homes and rejoin the more for- 


\section{The Life of the Weevil}

ward; and all are ready for work when the peas come into flower.

The great attraction of the insect world for the observer is that he can obtain a more or less general survey of the instincts, in their inexhaustible variety; for nowhere do we see the wonderful order of life's details more clearly revealed. Entomology, I know, does not appeal to everybody from this point of view : people have a poor opinion of the artless person absorbed in the behaviour of insects. To the terrible utilitarian, a measure of peas saved from the Weevil is of more importance than any number of observations which bring no immediate profit.

And who has told you, $\mathrm{O}$ man of little faith, that what is useless to-day may not be useful to-morrow? If we learn the habits of animals, we shall be better able to protect our property. Do not despise disinterested ideas, lest you live to rue the day. It is by accumulating ideas, whether immediately applicable or not, that mankind has done and will continue to do better to-day than yesterday, better in the future than in the present. If we live by peas and horse260 


\section{The Pea-Weevil: The Larva}

beans, which the Weevil disputes with us, we also live by knowledge, that mighty kneading-trough in which the dough of progress is mixed and fermented. Science is well worth a bean or two. Among other things, it tells us :

"The corn-chandler need not trouble to wage war upon the Weevil. By the time that the peas are stored, the harm is done; it is irreparable, but not transmissible. The untouched seeds have nothing to fear from the proximity of the seeds attacked, however long they may remain together. The Bruchus will issue from the latter when her time comes; she will fly out of the granary, if escape be possible; if not, she will die without in any way infesting the seeds that are still sound. No eggs, no new generation will ever be seen on the dried peas in our storehouse; nor will any damage be caused by the feeding of the adult."

Our Bruchus is not a sedentary inhabitant of the granaries: she needs the open air, the sunshine, the freedom of the fields. Very frugal on her own behalf, she absolutely disdains the hardness of the legumen; all that her slender snout requires is a few 


\section{The Life of the Weevil}

honeyed mouthfuls sipped from the flowers. The larva, on the other hand, demands the soft bread of the green pea still growing inside the pod. For these reasons, the storehouse knows no further multiplication on the part of the ravager introduced at the beginning.

The origin of the mischief lies out of doors. It is here more than elsewhere that we ought to keep a watch on the Weevil's misdeeds, were it not that we are nearly always unarmed when it comes to fighting against insects. Indestructible because of their numbers, their small size, their sly cunning, the little creatures laugh at man's anger. The gardener fumes and curses; the Weevil remains unconcerned: imperturbably she continues to levy her tithe.

Fortunately, we have assistants, more patient and more clear-sighted than ourselves. In the first week of August, when the adult Bruchus is beginning to move away, I make the acquaintance of a little Chalcis, the protector of our peas. In my rearingjars, a number of her comes out of the Weevil's home before my eyes. The female has a red head and thorax and a black abdo- 


\section{The Pea-Weevil: The Larva}

men, with a long boring-tool. The male, a little smaller, is clad in black. Both sexes have dull-red legs and thread-like antennx.

In order to leave the pea, the exterminator of the Bruchus opens herself a window in the centre of the disk which the Weevil's grub has bored in the skin with a view to its future deliverance. The devoured has prepared the way out for the devourer. This detail enables us to guess the rest.

When the preliminaries of the metamorphosis are finished, when the exit-hole is bored, furnished with its lid, a surface cuticle, the Chalcis comes bustling along. She inspects the peas, still on the plant, in their pods; she tries them with her antennx; she discovers, hidden under the general outer wrapper of the pod, the weak points in the ceiling formed by the skin. Then, raising her sounding-rod, she thrusts it through the pod and pierces the thin lid. However deeply secreted in the centre of the pea, the Weevil, whether larva or nymph, is reached by the long implement. It receives an egg in its tender flesh; and the trick is done. Without any chance of defence, for it is by now either a torpid grub or else a nymph, 


\section{The Life of the Weevil}

the corpulent infant will be drained to the skin.

What a pity that we are not able at will to promote the multiplication of this zealous exterminator! Aias, our agricultural auxiliaries have us in a disappointing vicious circle: if we wish to obtain the assistance of large numbers of the Chalcids that bore holes in peas, we must first have large numbers of Pea-weevils! 


\section{CHAPTER XIII}

\section{THE HARICOT-WEEVIL}

I $F$ there is a Heaven-sent vegetable on earth, it is the haricot bean. It has every good quality in its favour: it is soft to the tooth, of an agreeable flavour, plentiful, cheap and very nutritious. It is a vegetable flesh which, without being repulsive or dripping with blood, is as good as the cut-up horrors in the butcher's shop. To emphasize its services to mankind, the Provençal idiom calls it gounflo-gus, the poor man's bellows. ${ }^{1}$

Blessed bean, consoler of the poor, yes, you easily fill out the labourer, the honest and capable worker who has drawn the wrong number in life's mad lottery; kindly bean, with three drops of oil and a dash of vinegar, you were the favourite dish of my boyhood; and even now, in the evening of my days,

$1 \mathrm{Or}$, if the reader prefers, the Swell-belly. Gus, in the Provençal dialect, means both "guts" and "bigger." - Translator's Note. 


\section{The Life of the Weevil}

you are welcome to my humble porringer. We shall be friends to the last.

To-day it is not my intention to extol your deserts: I want to ask you a question, simply out of curiosity. What is your country of origin? Did you come from Central Asia, with the horse-bean and the pea? Did you belong to the collection of seeds which the first pioneers of husbandry handed to us from their garden patch? Were you known to antiquity?

Here the insect, an impartial and wellinformed witness, answers:

"No, in our parts antiquity did not know the haricot. The precious legumen did not reach our country by the same road as the broad bean. It is a foreigner, introduced into the old continent at a later date."

The insect's statement merits serious examination, supported as it is by very plausible arguments. Here are the facts.

Though I have followed agricultural matters closely for many years, I have never seen the haricots attacked by any ravager whatever of the insect series, nor in particular by the Bruchi, the licensed despoilers of leguminous seeds. 


\section{The Haricot-Weevil}

I question my peasant neighbours on this point. They are men who keep a sharp look out where their crops are concerned. To touch their property is a heinous crime, quickly discovered. Besides, there is the housewife, who would not fail to find the malefactor as she shells the haricots intended for the pot, conscientiously fingering them one by one before dropping them into a plate.

Well, one and all reply to my question with a smile in which I read their disbelief in my knowledge of the smaller creatures:

"Sir," they say, "learn that there are never any worms in the haricot. It is a blessed bean and respected by the Weevil. The pea, the broad bean, the lentil, the everlasting pea, the chick-pea, all have their vermin; this one, lou gounflo-gus, never. What should we poor people do if the Courcoussoun tried to rob us of it?"

The Curculio in fact despises it, displaying a very strange contempt when we consider the fervour with which the other legumina are attacked. All, down to the meagre lentil, are eagerly despoiled; and the haricot, so tempting both in size and in flavour, 


\section{The Life of the Weevil}

remains unharmed. It baffles the understanding. For what reason does the Bruchus, who passes without hesitation from the excellent to the indifferent and from the indifferent to the excellent, disdain this delicious seed? She leaves the everlasting pea for the green pea, she leaves the green pea for the broad bean and the vetch, accepting the niggardly scrap and the rich cake with equal satisfaction; and the attractions of the haricot leave her uninterested. Why?

Apparently because this legumen is unknown to her. The others, whether natives or acclimatized foreigners from the east, have been familiar to her for centuries; she tests their excellence year by year and, relying on the lessons of the past, she bases her forethought for the future upon ancient custom. She suspects the haricot as a newcomer whose merits she has still to learn.

The insect tells us emphatically that the haricot is of recent date. It reached us from very far away, surely from the New World. Every edible thing attracts those whose business it is to make use of it. If the haricot had originated in the old continent, it would have had its licensed consumers, 268 


\section{The Haricot-Weevil}

after the manner of the pea, the lentil and the others. The smallest leguminous seed, often no bigger than a pin's head, feeds its Bruchus, a dwarf that nibbles it patiently and hollows it into a dwelling, whereas the plump and exquisite haricot is spared!

This strange immunity can have but one explanation: like the potato, like maize, the haricot is a present from the New World. It arrived in Europe unaccompanied by the insect that battens on it regularly in its native land; it found in our fields other seedeaters, which, because they did not know it, despised it. In the same way, the potato and maize are respected over here, unless their American consumers are imported with them by accident.

The insect's report is confirmed by the negative evidence of the ancient classics: the haricot never appears on the rustic table of their peasants. In Vergil's second Eclogue, Thestylis is preparing the reapers' repast: Thestylis et rapido fessis messoribus astu Allia serpyllumque herbas contundit olentes. ${ }^{1}$

1 "And Thestylis wild thyme and garlic beats For harvest hinds, o'erspent with toil and heats."Pastorals, ii, Dryden's translation. 269 


\section{The Life of the Weevil}

The mixture is the equivalent of the aioli dear to the Provençal palate. It sounds very well in verse, but it lacks substance. On such an occasion men would prefer such solid fare as a dish of red haricots seasoned with chopped onions. Capital: that ballasts the stomach, while remaining just as countrified as garlic. Thus filled, in the open air, to the chirping of the Cicadæ, the gang of harvesters could take a brief mid-day nap and gently digest their meal in the shade of the sheaves. Our modern Thestyles, differing so little from their classic sisters, would take good care not to forget the gounflo-gus, that thrifty stand-by of big appetites. The Thestylis of the poet does not think of it, because she does not know it.

The same author shows us Tityrus offering a night's hospitality to his friend Melibœus, who, driven from his property by the soldiers of Octavius, goes off limping behind his flock of goats.

"We shall have chestnuts," says Tityrus, "cheese and fruits."

History does not say if Melibœus allowed himself to be tempted. It is a pity, for during the frugal meal we might have learnt, 


\section{The Haricot-Weevil}

in a more explicit fashion, that the shepherds of olden time had to do without the haricot.

Ovid tells us, in a delightful passage, of the manner in which Philemon and Baucis welcomed the gods unawares as guests in their humble cottage. On the three-legged table steadied by means of a potsherd, they served cabbage-soup, rancid bacon, eggs turned for a moment over the hot cinders, cornelian cherries preserved in brine, honey and fruits. One dish is lacking amid this rustic magnificence, an essential dish which no Baucis of our country-side would ever forget. The bacon-soup would have been followed, inevitably, by a plateful of haricots. Why does Ovid, the poet so rich in details, fail to speak of the bean which would have looked so well on the bill of fare? The reply is the same: he cannot have known of it.

In vain do I go over the little that my reading has taught me of rustic food in ancient times: I have no recollection of the haricot. The stew-pots of the vine-dresser and the harvester tell me of the lupin, the broad bean, the pea and the lentil; but they never mention the bean of beans. 


\section{The Life of the Weevil}

The haricot has a reputation of another kind, a reputation more flatulent than flattering. You eat it and then, as the saying goes, the sooner you are off the better. It therefore lends itself to the coarse jests loved by the rabble, especially when these are put into words by the shameless genius of an Aristophanes or a Plautus. What stage effects could have been produced by the merest allusion to the noisy bean, raising guffaws of laughter from the mariners of Athens or the street-porters of Rome! Did the two comic poets, in the unfettered gaiety of a language less reserved than ours, ever refer to the virtues of the haricot? Not once. They are quite silent on the subject of the sonorous bean.

The word haricot itself sets us thinking. It is an outlandish term, related to none of our expressions. Its turn of language, which is alien to our combinations of sounds, suggests to the mind some West-Indian jargon, as do caoutchouc and cocoa. Does the word, as a matter of fact, come from the American Redskins? Did we receive, together with the bean, the name by which it is called in its native country? Perhaps so; 


\section{The Haricot-Weevil}

but how are we to know? Haricot, fantastic haricot, you set us a curious linguistic problem.

The Frenchman calls it also faséole, flageolet. The Provençal dubs it faïoì and faviou; the Catalan fayol; the Spaniard faseolo; the Portuguese feyâo; the Italian faguilo. Here I am on familiar ground: the languages of the Latin family have kept, with the inevitable terminal modifications, the ancient word faseolus.

Now, if I consult my dictionary, I find: faselus, phaselus, faseolus, phaseolus, haricot. Learned vocabulary, permit me to tell you that your translation is wrong: phaselus or phaseolus cannot mean haricot. And the incontestable proof is in the Georgics, ${ }^{1}$ where Virgil tells us the season at which to sow the faseolus. He says:

Si vero viciamque seres vilemque phaselum. ... Haud obscura cadens mittet tibi signa Bootes,"2 Incipe et ad medias sementem extende pruinas.

1 Book i., line 227 et seq. -Author's Note.

2 "Vile vetches would you sow, or lentils lean?

The growth of Egypt, or the kidney-bean?

Begin when the slow Waggoner descends,

Nor cease your sowing till mid-winter ends." 273 


\section{The Life of the Weevil}

Nothing is clearer than the teaching of the poet, who was wonderfully well-informed on agricultural matters: we must begin to sow the phaselus when the constellation Bootes disappears at sunset, that is to say, at the end of October, and continue doing so until the middle of the winter.

These conditions put the haricot out of the question: it is a chilly plant, which would not withstand the slightest frost. The winter would be fatal to it, even in the climate of the south of Italy. On the other hand, the pea, the broad bean, the everlasting pea and others, better able to resist the cold because of their country of origin, have nothing to fear from an autumn sowing and thrive during the winter, provided that the climate be fairly mild.

What then does the phaselus of the Georgics stand for, that problematical bean which has handed down its name to the haricot in the Latin languages? Remembering the contemptuous epithet vilis with which the poet stigmatizes it, I feel inclined to look upon it as the chickling vetch, the coarse square pea, the jaisso despised by the Provençal peasant. 


\section{The Haricot-Weevil}

The problem of the haricot had reached this stage, almost elucidated by the insect's evidence alone, when an unexpected document came and gave me the last word of the riddle. It is once more a poet-and a very famous poet-M. José Maria de Heredia, ${ }^{1}$ who comes to the naturalist's aid. Without suspecting the service which he is rendering me, the village schoolmaster lends me a magazine $^{2}$ in which I read the following conversation between the masterly chaser of sonnets and a lady journalist who asks him which of his works he prefers:

"'What would you have me say?' asks the poet. 'You place $m e$ in a great difficulty. . . . I do not know which sonnet I like best: they all cost me terrible pains to write.... Which do you yourself prefer?'

" 'How can I possibly make a choice, my dear master, out of so many jewels, each of which is perfectly beautiful? You flash pearls, emeralds and rubies before my astonished eyes; how can I decide to prefer

1 The academician (1842-1905). -Translator's Note.

2 Annales politiques et littéraires Les Enfants jugés par leur pères. Christmas number, 1901.-Author's Note. 


\section{The Life of the Weevil}

the emerald to the pearl? The whole necklace throws me into an ecstasy of admiration.'

" 'Well, as for me, there is something of which I am prouder than of all my sonnets, something which has done more than my verses to establish my fame.'

"I open my eyes wide:

"'What is that?' I ask.

"The master gives me a mischievous glance; then, with that fine light in his eyes which fires his youthful features, he exclaims. triumphantly:

"I have discovered the etymology of the word haricot.'

"I was too much astounded even to laugh. “" 'What I tell you is perfectly serious.' " 'My dear master, I knew your reputation for profound scholarship; but from that to imagining that you owed your fame to discovering the etymology of the word haricot: ah no, I should never have expected that! Can you tell me how you made the discovery?'

" "With pleasure. It was like this: I found some particulars about haricots when 276 


\section{The Haricot-Weevil}

searching through a fine sixteenth-century work on natural history, Hernandez' $D e$ Historia plantarum novi orbis. The word haricot was unknown in France until the seventeenth century: we used to say fève or phaséol; in Mexican, ayacot. Thirty varieties of haricot were cultivated in Mexico before the conquest. They are called ayacot to this day, especially the red haricot, with black or violet spots. One day, at Gaston Paris' house, I met a great scholar. On hearing my name, he rushed at me and asked if it was I who had discovered the etymology of the word haricot. He was absolutely ignorant of the fact that I had written poems and published Les Trophées. ...',

What a glorious jest, to place the jewellery of his sonnets under the protection of a bean! I in my turn am delighted with the ayacot. How right $I$ was to suspect that strange word haricot of being an AmericanIndian idiom! How truthful the insect was when it declared, in its own fashion, that the precious seed reached us from the $\mathrm{New}$ World! While retaining its first name, or 


\section{The Life of the Weevil}

something very nearly, the bean of Montezuma, the Aztec ayacot, found its way from Mexico to our kitchen-gardens.

But it came to us unaccompanied by the insect which is its titular consumer, for there must certainly be a Weevil in its native country which levies tribute on the generous bean. Our indigenous nibblers of seeds have disowned the foreigner; they have not yet had time to become familiar with it and to appreciate its merits; they have prudently refrained from touching the ayacot, which aroused suspicion because of its novelty. Until our own days, therefore, the Mexican bean remained unharmed, differing curiously in this from our other legumina, all of which are eagerly devoured by the Weevil.

This state of things could not last. If our fields do not contain the haricot-loving insect, the New World knows it well. In the ordinary way of commercial exchange, some sack of worm-eaten beans was bound to bring it to Europe. The invasion was inevitable.

Indeed, according to data in my possession, it seems recently to have taken place. Three or four years ago, I received from Mail278 


\section{The Haricot-Weevil}

lanne, in the Bouches-du-Rhône, what I was vainly seeking in my neighbourhood, although I cross-examined both farmers and housewives, astonishing them greatly by my questions. No one had ever seen the pest of the haricots; no one had ever heard of it. Friends who knew of my enquiries sent me from Maillanne, as I have said, the wherewithal to satisfy fully my curiosity as a naturalist. It consisted of a bushel of haricots outrageously spoilt, riddled with holes, changed into a sort of sponge and swarming inside with innumerable Bruchi, which recalled the Lentil-weevil by their diminutive size.

The senders told me of the damage suffered at Maillanne. The odious insect, they said, had destroyed the best part of the crop. A veritable plague, the like of which had never been known before, had fallen upon the haricots, leaving the housekeeper hardly any with which to garnish her stew. Of the culprit's habits, of its way of going to work nothing was known. It was for me to find out this by experiment.

Quick, then, let us experiment! Circumstances favour me. We are in the 


\section{The Life of the Weevil}

middle of June; and I have in the garden a row of early haricots, black Belgian haricots, sown for cooking-purposes. Though it mean sacrificing the precious vegetable, let us loose the terrible destroyer on the mass of verdure. The development of the plant is at just the right stage, if I may go by what the Pea-weevil has already shown me: there are plenty of flowers and also of pods, still green and of all sizes.

I put two or three handfuls of my Maillanne haricots in a plate and place the swarming mass full in the sunlight on the edge of my bed of beans. I can imagine what will happen. The insects which are free and those which the stimulus of the sun will soon set free will take to their wings. Finding the fostering plant close by, they will stop and take possession of it. I shall see them exploring the pods and flowers and I shall not have long to wait before I witness the laying. That is how the Pea-Weevil would act under similar conditions.

Well, no: to my confusion, matters do not fall out as I foresaw. For a few minutes the insects bustle about in the sunlight, opening and closing their wing-cases to ease the 280 


\section{The Haricot-Weevil}

mechanism of flight; then one by one they fly off. They mount high in the luminous air; they grow smaller and smaller and are soon lost to view. My persevering attention meets with not the slightest success: not one of the fly-aways settles on the haricots.

After tasting the joys of liberty to the full, will they return this evening, to-morrow, the day after? No, they do not return. All the week, at favourable hours, I inspect the rows of beans, flower by flower, pod by pod; never a Weevil do I see, never an egg. And yet it is a propitious time of year, for at this moment the mothers imprisoned in my jars are laying their eggs profusely on the dry haricots.

Let us try at another season. I have two other beds which I have had sown with the late haricot, the red cocot, partly for the use of the household, but principally for the sake of the Weevils. Arranged in convenient rows, the two beds will yield their crops one in August, the other in September and later.

I repeat with the red haricot the experiment which I made with the black. On several occasions, at opportune times, I 28 I 


\section{The Life of the Weevil}

release into the tangle of verdure large numbers of Bruchi from my glass jars, the general depot. Each time the result is plainly negative. In vain, all through the season, I repeat my almost daily search, until both the crops are exhausted: I can never discover a single colonized pod, nor even a single Weevil perched upon the plant.

And yet this is not for lacking of watching. My family are enjoined not to touch any part of certain rows which I reserve for my purposes; they are told to mind the eggs which might occur on the pods gathered. I myself examine the beans brought from my own or the neighbouring gardens, before handing them to the housekeeper to be shelled. All my trouble is wasted: there is nowhere a trace of any laying.

To these experiments in the open air I add others under glass. I place in long, narrow flasks fresh pods hanging from their stalks, some green, others mottled with crimson and containing seeds which are nearly ripe. Each flask receives its complement of Weevils. This time I obtain eggs, but they do not inspire me with much hope: the mother has laid them on the sides of the 282 


\section{The Haricot-Weevil}

flasks and not on the pods. No matter: they hatch. For a few days I see the grubs roaming about, exploring the pods and the glass with equal zeal. In the end they all die, from the first to the last, without touching the food provided.

The conclusion to be drawn is obvious: the young and tender haricot is not the thing for them. Unlike the Pea-weevil, the Haricot-weevil refuses to entrust her family to beans that are not hardened by age and desiccation; she declines to stop on my seedpatch, because she does not find the provisions which she requires.

Then what does she want? She wants old, hard beans, which clatter on the ground like little pebbles. I will satisfy her. I place in my flasks some very hard, tough pods, which have been long dried in the sun. This time the family prospers; the grubs bore through the parched shell, reach the seeds, enter them; and henceforth all goes well as well can be.

To all appearances, this is how the Weevil invades the farmer's granary. Some haricots are left standing in the fields until both plants and pods, baked by the sun, are per283 


\section{The Life of the Weevil}

fectly dry. This will make them easier to beat in order to separate the beans. It is now that the Weevil, finding things as she wants them, begins her laying. By getting in his crop a little late, the peasant gets the marauder into the bargain.

But the Bruchus attacks more especially the seeds in our stores. Copying the Cornweevil, who eats the wheat in our granaries and disregards the cereal swaying in the ear, in the same way she abhors the tender bean and prefers to make her home in the peace and darkness of our warehouses. She is a formidable enemy of the corn-chandler rather than of the farmer.

What a fury of destruction, once the ravager is installed amidst our hoards of beans! My flasks proclaim the fact aloud. A single haricot-bean harbours a numerous family, often as many as twenty. And not only one generation exploits it, but quite three or four in the year. So long as any edible matter remains within the skin, so long do new consumers settle down in it, until in the end the haricot becomes a loathsome sugar-plum stuffed with stercoral droppings. The skin, which the grubs refuse to eat, is a sack 284 


\section{The Haricot-Weevil}

pierced with round holes numbering as many as the inhabitants that have left it; the contents yield to the pressure of the finger and spread into a disgusting paste of floury excreta. The bean is a complete wreck.

The Pea-weevil, living alone in its seed, eats only enough to make a little hollow for the nymph. The rest remains intact, so that the pea is able to sprout and can even serve as food, if we dismiss any unreasonable repugnance from our mind. The American insect does not exercise this self-restraint: it empties its haricot entirely, leaving a skinful of filth which I have seen refused by the pigs. America does not do things by halves when she sends us her plagues of insects. We had to thank her for the Phylloxera, the disastrous Louse against whom our vinegrowers wage incessant war; and now we have to thank her for the Haricot-weevil, a serious future menace. A few experiments will give us an idea of the danger.

For nearly three years there have stood, on the table of my insect laboratory, some dozens of jars and bottles closed with gauze covers which prevent escape, while permitting constant ventilation. These are the 


\section{The Life of the Weevil}

cages containing my wild animals. In them I rear the Haricot-weevil, varying the diet as I please. They teach me among other things that the insect, far from being exclusive in the choice of its establishments, will make itself at home in our different legumina, with very few exceptions.

All the haricots suit it, whether black or white, red or striped, small or large, those of the last crop or those many years old and almost too hard to boil. The loose beans are attacked by preference, as being less troublesome to invade; but, when there are no shelled beans available, those covered by their natural sheath are just as zealously exploited. The new-born grubs are well able to reach them through the pod, which is often as stiff as parchment. This is how the beans are raided in the fields.

Another highly-appreciated bean is the long-podded dolichos, known among our people as lou faioù borgné, the one-eyed haricot, because of the dark speck which gives the umbilicus the look of a black eye. I even fancy that my boarders show a marked predilection for this bean.

So far, there is nothing abnormal: the 286 


\section{The Haricot-Weevil}

Bruchus has not gone beyond the botanical genus Phaseolus. But here is something that increases the danger and shows us the phaseolus-lover in an unexpected light. The Bruchus accepts without the least hesitation the dried pea, the broad bean, the everlasting pea, the vetch, the chick-pea; she passes from one to the other, always satisfied; her family live and prosper in all these legumina as well as they do in the haricot. Only the lentil is refused, perhaps because of its insufficient size. What a dread robber this American Weevil is!

The evil would become still greater if, as I feared at first, the ever greedy insect passed from leguminous seeds to cereals. This it does not do. When installed in my jars with a heap of wheat, barley, rice or maize, the Bruchus invariably dies without offspring. The result is the same with horny seeds, such as coffee-beans; with oleaginous seeds, such as those of the castor-oil-plant or of the sunflower. Nothing outside the legumina suits the Bruchus. Notwithstanding these limitations, its portion is a very extensive one; and it uses and abuses it with the utmost energy.

The eggs are white and drawn out into 287 


\section{The Life of the Weevil}

a tiny cylinder. They are scattered anyhow and anywhere. The mother lays them either singly or in little groups, on the sides of the jar as well as on the haricots. Her heedlessness is such that she will even fasten them to maize, castor-oil-seeds, coffee-beans or other seeds, on which the family are doomed soon to perish, finding no food to their liking. What is the use of maternal foresight here? Left no matter where, under the heap of beans, the eggs are always well-placed, for it is the new-born grubs' business to seek and find the spots at which to effect an entrance.

The egg hatches in five days at most. Out of it comes a tiny white creature, with a red head. It is a mere speck, just visible to the naked eye. The grub is swollen in front, to give more strength to its tool, the chisel of its mandibles, which has to break through the tough seed, hard as wood. The larvæ of the Buprestes and the Capricorns, which tunnel through the trunks of trees, are similarly shaped. As soon as it is born, the crawling worm makes off at random, with an activity which we should hardly expect in one 


\section{The Haricot-Weevil}

so young. It roams about, anxious to find board and lodging as soon as possible.

It attains its object, for the most part, within the twenty-four hours. I see the worm making a hole in the tough skin of the seed; I watch its efforts; I catch sight of it half-sunk in the beginning of a gallery whose entrance is dusty with white flour, the refuse from the boring. It works its way in and penetrates into the heart of the seed. Its evolution is so rapid that it will emerge in the adult form in five weeks' time.

This hasty development permits several generations to take place in the course of the year. I have seen four. On the other hand, an isolated couple supplied me with a family of eighty. Let us consider only half this number, to allow for the two sexes, which I take to be equally represented. At the end of the year, the couples resulting from this source will therefore be represented by the fourth power of forty, reaching in terms of larvæ the frightful total of over two and a half millions. What a heap of haricots such a legion would destroy!

The larva's methods remind us at all 289 


\section{The Life of the Weevil}

points of what the Pea-weevil showed us. Each grub digs itself a cell in the floury mass, while respecting the skin in the form of a protective disk, which the adult will easily be able to push out at the moment of leaving. Towards the end of the larval phase, the cells show through on the surface of the bean as so many dark circles. At last the lid falls off, the insect leaves its cell and the haricot remains pierced with as many holes as it had grubs feeding on it.

Very frugal, satisfied with a few floury scraps, the adults seem not at all anxious to abandon the heap so long as beans worth exploiting remain. They mate in the interstices of the stack; the mothers scatter their eggs at random; the young grubs make themselves at home, some in the untouched haricots, some in the beans that are holed but not yet exhausted; and the swarming is repeated every five weeks throughout the summer, after which the last generation, the one born in September or October, slumbers in its cells till the return of the warm weather.

If ever the spoiler of the haricots became too ominously threatening, it would not be very difficult to wage a war of extermination 


\section{The Haricot-Weevil}

upon her. We know from her habits the best tactics to follow. She ravages the dry and gathered crop, stored in the granaries. It is an irksome matter to attend to her in the open fields; and it is also almost useless. The bulk of her business is conducted elsewhere, in our warehouses. The enemy settles down under our roof, within our reach. This being so, with the aid of insecticides defence becomes relatively easy. 


\section{CHAPTER XIV}

THE IRIS-WEEVIL

PLANTs, with their fruits, have been $P$ and still are the main sustenance of mankind. The ancient Paradise of which the eastern legends tell us had no other foodresources. It was a delicious garden with cool rivulets and fruits of every kind, including the apple that was to be so fatal to us. On the other hand, from a very early period, our ills sought to obtain relief by the virtues of simples, virtues that were sometimes real and sometimes, indeed most frequently, imaginary. Our knowledge of plants is thus as old as our infirmities and our need of food.

Our knowledge of insects, on the contrary, is quite recent. The ancients knew nothing of the lesser animals, did not even deign to glance at them. "This disdain is by no means extinct. We are vaguely familiar with the work of the Bee and the Silk-worm; we have heard people speak of the industry of the 


\section{The Iris-Weevil}

Ant; we know that the Cicada sings, without having a very exact notion of the singer, who is confused with others; we have perhaps vouchsafed a careless glance to the splendours of the Butterflies; and with this, for the immense majority, entomology begins and ends. What layman would risk naming an insect, even one of the more remarkable?

The Provençal peasant, who is pretty quick at observing things that have to do with the land, has a dozen expressions at the very most to denominate indiscriminately the vast world of insects, though he possesses a very rich vocabulary by which to describe plants. This or that bit of weed which one would think was known only to the botanists is to him a familiar object and bears a special name of its own.

Now the vegetarian insect is, as a rule, scrupulously faithful to its food-plant, so that, with botany and entomology going hand in hand, the beginner is spared many a hesitation. The plant exploited gives the name of the exploiting insect. Who, for instance, does not know the splendid yellow iris? The green cutlasses of its leaves and its yellow cluster of flowers are mirrored in the 


\section{The Life of the Weevil}

brooks. The pretty, green Tree-frog, swelling his throat into a bagpipe, sits and croaks in it at the approach of rain.

Come nearer. On its trivalvular capsules, which the heat of June is beginning to ripen we shall see a curious sight. Here, a restless company of thick-set, rusty-red Weevils are embracing, separating and coming together again. They are working with their beaks and are busy mating. This shall be our subject for to-day.

Our current language has not given them a name, but history has inflicted on them the fantastic appellation of Mononychus pseudoacori, FAB. Literally interpreted and amplified, this means "the one-nailed insect of the mock acorus," acorus in its turn being derived from $a$, privative, and $к$ óp $\eta$ the pupil of the eye. The grammarian's scalpel, searching and dissecting the entrails of words, is liable, like the anatomist's scalpel, to meet with strange adventures. Let us explain this scientific jargon, which at first sight seems utterly meaningless.

The plant helpful to those without pupils-that is to say, the weak-sighted-is the acorus, or sweet flag, which the medical 


\section{The Iris-Weevil}

science of antiquity prescribed for certain affections of the eyes. Its sword-shaped leaves bear some resemblance to those of the yellow iris. Ours, therefore, is the false acorus, a deceptive image of the famous medicinal plant.

As for the one nail, this is explained by the tarsi, the insect's six fingers, each of which is armed with a single claw instead of the usual two. This strange exception certainly deserved to be pointed out; all the same, any one must prefer Iris-weevil to Mononychus pseudo-acori. Neglecting all pomp and ostentation, the everyday name does not topsy-turvify the mind and makes straight for the insect.

In June, I pluck some stems of yellow iris surmounted by their bunch of capsules, which are already large and keep fresh and green for a long time. The exploiting Weevil goes with them. In captivity, under the trellis-work of a wire-gauze cover, the work proceeds just as it does beside the brook. Most of the insects, singly or in groups, stand at convenient points. With their rostrum plunged into the green hull, they sip and sup indefinitely. When they retire 


\section{The Life of the Weevil}

sated, a drop of gum oozes out which, after drying on the orifice of the well, marks the spot which they have drained.

Others are grazing. They attack the tender capsules and skin them almost down to the seeds. Despite their tiny size, they nibble gluttonously; when several of them are feasting together, they gnaw large areas; but they do not actually reach the seeds, the food reserved for the larvæ. Many of them stroll about, seem not to care for eating. They meet, tease one another for a moment and couple.

I do not succeed in observing the method of laying, which, however, must be much the same as that of the other Weevils who use a sound. The mother apparently bores a well with her rostrum; she then turns and places the egg in position by means of her oviscapt. I have seen larvæ quite recently hatched. The vermin occupy the interior of a seed whose substance is becoming organized and beginning to grow firm.

At the end of July, I open some capsules brought on the same day from the banks of the stream. In most of them the insect occurs in the three forms of larva, nymph 296 


\section{The Iris-Weevil}

and adult. Each of the three cells of the fruit contains a row of some fifteen seeds, flat and pressed tightly one against the other. The grub's portion consists of three contiguous seeds. The one in the middle is entirely consumed, excepting the husk, which is too tough; the two at either end are simply bitten into. The result is a house with three rooms, the central one shaped like a ring, the two outer ones dug cup-wise.

With its fifterin seeds, each compartment of the fruit is therefore able to shelter five larvæ at most, providing them with a fitting ration and a detached villa which does not interfere with the neighbours. However, on the back of the capsule, we count, for each cell, about twenty perforations, the edge of which is marked by a little wart either of gum or of some brown substance. These are so many soundings made by the Weevil's rostrum.

Some of these have to do with the feeding: they are the refreshment-bars at which the colonists of the capsule have taken a snack. The others relate to the laying of the eggs and the placing of them, one by one, in the midst of the victuals. Outwardly, there is 


\section{The Life of the Weevil}

nothing to distinguish the speck which marks a refreshment-bar from that which marks a cradle; therefore it is impossible, by merely counting the borings, to tell exactly how many eggs have been confided to the capsule. Let us strike an average. Of the twenty punctures in one shell, let us consider ten as relating to the eggs. These would be twice as many as the cell could feed. What then has become of the surplus?

Here we are reminded of the Weevil who scatters over her pea-pod an excessive number of eggs, out of all proportion to the provisions which it contains. In the same way, on the iris, the pregnant mother takes no stock of the rations; she peoples the already populated and fills the overflowing. Her procreative fury does not reckon with the future. Let those thrive who may.

We can understand Verbascum thapsus allowing itself forty-eight thousand seeds when the germination of a single one would suffice to maintain the species: its distaff is a treasure-house of food by which a host of consumers will profit. But we cannot understand the Pea-weevil, the Iris-weevil and many others who, though not exposed 298 


\section{The Iris-Weevil}

to a serious thinning, nevertheless produce excessive families without taking into account the resources at their disposal.

For lack of room on the seed-capsule of the iris, of the ten guests in one shell four or five at most will survive. As for the disappearance of the rest, we need not seek the cause in the massacring of rivals, though the struggle for existence is fruitful in such crimes. The Weevil's grub is too pacific a creature to wring the neck of those which get in its way. I prefer the explanation which I gave in the case of the Pea-weevil. The late-comers, finding the best places taken, allow themselves to die without striving to dislodge the others. For those first installed, a plentiful board and life; for those which lag behind, famine and death.

In August the adults begin to appear outside the seed-pods of the iris. The larva has not the talent which the Pea-weevil's grub possesses: it does not, by patient nibbling, make any sort of preparation for the exodus. It is the perfect insect itself that contrives the exit-way, which consists of a round hole bored through the tough husk of the seed and the thick wall of the fruit. 


\section{The Life of the Weevil}

Finally, in September, the capsules of the iris turn brown and the three valves become unfastened; the house threatens to fall to pieces. Before it becomes untenable, the last occupants hasten to clear out, each by its round window. They will spend the winter in the neighbourhood, under some kind of shelter; then, when spring returns and the iris is yellow with flowers, the colonizing of the capsules will begin all over again.

The flora of my district, not far from the spots frequented by our insect, in addition to the yellow iris comprises three other species. On the neighbouring hills, among the rock-roses and the rosemaries, the dwarf iris abounds (I. chamoiris, BERTOL.), with flowers of varying colour : they are sometimes purple, sometimes yellow or white and sometimes attired in a mixture of the three hues. The plant is barely a hand's-breadth in height, but its flowers are quite as large as those of the other species.

On the same hills, at points where the rains have left a little moisture, the spurious iris (I. spuria) forms a glorious carpet. It is tall, slender-leaved and decked with flowers of rare beauty. Lastly, near the 


\section{The Iris-Weevil}

brook where I have been observing the Irisweevil, is the Gladwyn iris, or leg-of-mutton iris (I. fatidissima, LIN.), whose leaves, when bruised, give a faint scent of mutton and garlic. Its seeds are a fine orange-red, a specific characteristic which recurs no elsewhere.

Altogether, without counting such foreigners as may have found their way into the flower-gardens around, we see four varieties of native iris at the Weevil's disposal. They have the same sort of capsules, all equally bulky and equally rich in seeds, whose properties as food cannot differ much. Moreover, the four plants flower at the same season. And of these four, which would permit her greatly to extend her race, the Weevil invariably selects the yellow iris. I have never found the insect established in the capsules of one of the other three.

For what reasons does she prefer niggardly uniformity to varied abundance? The tastes of the adult insect and those of the larva must have something to say to the choice. The adult feeds on the fleshy hull of the capsules; the grub, on the other hand, lives entirely on the seeds, which are not yet 


\section{The Life of the Weevil}

hardened and are full of juice. Are the appetites of the adult insect satisfied with the fruit of any kind of iris? This can be tested.

Under the trellis-work of a wire cover, I place before the Weevil some green capsules of different origins. Jumbled up with the fruits of the yellow iris are those of the dwarf iris, the leg-of-mutton iris and the spurious iris. To these I add some foreign capsules, those of the pale Turkey iris (I. pallida, LAM.) and of the great bulbous iris (I. xiphoides, EHRH.), which differs so greatly from the others by the bulb which takes the place of the usual rhizone.

Well, all these fruits are accepted as eagerly as those of the yellow iris. The Weevil riddles them with punctures, strips them bare, pierces them with windows. The capsules of my choosing and those from the banks of the stream, which are normally used, often lie side by side; the consumer makes no distinction between them, but goes without hesitation from one to the other, attacking them with a zeal which is in no wise impaired by the novelty of the dish. It considers everything good to eat, so long as 


\section{The Iris-Weevil}

it comes from an iris of some sort or other.

And this is not, as one might reasonably suppose, an aberration caused by the tedium of captivity. I have found in the harmas ${ }^{1}$ on the tall stalks of the pale Turkey iris, a group of our Weevils feeding together on the green capsules. Whence came they, these pilgrims observed for the first time between my four walls? How did they learn, these colonists from the moist riverbanks, that an iris which provided excellent eating was flowering amid the aridities of my acre of pebbles? At any rate they left no part of the young capsules intact. The food discovered suited them very well. It was therefore impossible for me to profit by this windfall in order to ascertain whether the unfamiliar plant would serve for the establishment of the family.

Apart from the genus Iris, are there any other plants, its near botanical relations, whose fruits are accepted? I have vainly tried the trivalvular capsules of the corn-flag (Gladiolus segetum, GAWL.) and the

1 The enclosed piece of waste land on which the author used to study his insects in the wild state. Cf. The Life of the Fly: chap. i.-Translator's Note. 


\section{The Life of the Weevil}

globular capsules of two asphodels ( $A$ sphodelus luteus, LIN. and A. cerasiferus, GAY). The Weevil would have none of them. At most she dipped her rostrum into the greer capsules of the yellow asphodel, the common Jacob's staff. She tasted and then moved away. The dish was not to her liking; and hunger was unable to overcome her obstinate disdain. She would die of starvation sooner than touch victuals unhallowed by tradition.

It goes without saying that I found nothing in the way of eggs on the corn-flag or the two asphodels. What the insect regards as unfit for its own consumption is a fortiori refused when the grub's food is concerned. Nor was I any luckier with the various irises which I tried, the yellow iris excepted. Are we to attribute this refusal to the insect's captivity? No, for the capsules of the yellow iris were colonized fairly well under my wire covers. The fact is that, as soon as the establishment of the family comes into question, the Weevil abstains entirely from anything that is contrary to habit and remains firmly faithful to the laws and customs of the ancients. In short, I have never found the Weevil established 


\section{The Iris-Weevil}

elsewhere than in the capsules of the yellow iris, however appetizing the appearance of the others, especially those of the dwarf iris, which are exceedingly fleshy and very numerous in the spring. 


\title{
CHAPTER XV
}

\author{
THE CIONUS
}

A $\mathrm{N}$ insect, well known to every one, is $\mathrm{A}$ often but a stupid creature, while another, of which nothing is known, is of real value. When endowed with talents worthy of attention, it passes unrecognized; when richly clad and of hardsome appearance, it is familiar to us. We judge it by its coat and its size, as we judge our neighbour by the fineness of his clothing and the importance of the position which he fills. The rest does not count.

Of course, if it is to be honoured by the historian, it is best that the insect should enjoy popular renown. This saves the reader trouble, as he at once knows precisely what we are speaking of; furthermore, it shortens the story, which is not hampered by long and tedious descriptions. Moreover, if size facilitates observation, if elegance of shape and brilliance of costume 


\section{The Cionus}

captivate the eye, we should be wrong not to take this magnificence into our reckoning.

But far more important are the habits, the ingenious devices, which give a real charm to entomological study. Now it so happens that among the insects it is the largest, the most magnificent, that are generally the most inefficient : a freak of nature that recurs elsewhere. What can we expect of a Carabus, all shimmering with metallic gleams? Nothing but feasting amid the foam secre. ted by a murdered snail. What can we expect of the Cetonia, who looks as though she had escaped from a jeweller's show-case? Nothing but drowsy slumbers in the heart of a rose. These magnificœs cannot do anything; they have no craft, no trade.

If, on the contrary, we wish to see original inventions, artistic masterpieces and ingenious contrivances, we must apply to the humble creatures that are oftener than not unknown to any one. And we must not allow ourselves to be disgusted by the spots frequented. Ordure has beautiful and curious things in store for us, the like of which we should never find on the rose. The Mino- 


\section{The Life of the Weevil}

taur $^{1}$ has edified us by his domestic habits. Long live the modest! Long live the little!

One of these little ones, smaller than a peppercorn, will set us a great problem, full of interest but probably insoluble. The official nomenclators call it Cionus thapsus, FAB. If you ask me what Cionus means, I shall reply frankly that I have not the least idea. Neither the writer of these lines nor the reader is any the worse off for that. In entomology a name is all the better for meaning nothing but the insect named.

If an amalgam of Greek or Latin has a meaning that alludes to the insect's manner of living, the reality is often inconsistent with the word, because the nomenclator, working in a necropolis, has preceded the observer, who is concerned with the living species. Moreover, rough guesses and even glaring mistakes too often disfigure the records of the insect world.

At the present moment, it is the word thapsus that deserves reproach, for the plant ex-

${ }^{1}$ The essays on Minotaurus Typhceus will appear in the next volume of the series, to be entitled More Beetles. -Translator's Note. 


\section{The Cionus}

ploited by the Cionus is not the botanists' $V$ erbascum thapsus at all, but quite another plant, of wholly different character, Verbascum sinuatum. A lover of the way-side, having no fear of the ungrateful soil and the white dust, the scallop-leaved mullein is a southern plant which spreads over the ground a rosette of broad, fluffy leaves, the edges of which are gashed with deep, wavy incisions. Its flower-stalk is divided into a number of twigs bearing yellow blossoms whose staminal filaments are bearded with violet hairs.

At the end of May, let us open the umbrella, the collector's chief engine of the chase, underneath the plant. A few blows of a walking-stick on the chandelier ablaze with yellow flowers will bring down a sort of hail. This is our friend the Cionus, a roundish little creature, huddled into a globule on its short legs. Its costume is not lacking in elegance and consists of a scaly jacket flecked with black specks on an ash-grey background. The insect is distinguished above all by two large tufts of black velvet, one on its back and the other at the lower extremity of the wing-case. No other Weevil of our country-side wears the like. The rostrum is 


\section{The Life of the Weevil}

fairly long, powerful and depressed towards the thorax.

For a long while this Weevil, with her decoration of black spots, has occupied my mind. I should like to know her larva, which, as everything seems to prove, must live in the capsules of the scollop-leaved mullein. The insect belongs to the series that nibble at seeds contained in a shell; it ought to share their botanical habits. But vainly, whatever the season, do I open the capsules of the exploited plant: never do I find the Cionus there, nor its larva, nor its nymph. This little mystery increases my curiosity. Perhaps the dwarf has interesting things to tell us. I propose to wrest her secret from her.

It so happens that a few scollop-leaved mulleins are spreading their rosettes amid the pebbles of my enclosure. They are not populated, but I can easily colonize them with specimens from the country round about, obtained by a few battues over the umbrella. No sooner said than done. From May onwards I have before my door, without fear of disturbance by passing Sheep, the means 


\section{The Cionus}

of following the Cionus' doings, in comfort, at any hour of the day.

My colonies flourish. The strangers, satisfied with their new camping-ground, settle down on the twigs on which I have placed them. They browse and gently tease one another with their legs: many of them pair off and gaily spend their lives revelling in the sunshine. Those coupled together, one on top of the other, are subject to sudden lurches from side to side, as though impelled by the release of a vibrating spring. Pauses follow, of varying length; then the lurches are repeated, cease and begin again.

Which of the two supplies the motive force of this little piece of machinery? It seems to me that it is the female, who is rather larger than the male. The jerking would then be a protest on her part, an attempt to free herself from the embraces of her companion, who holds on despite all this shaking. Or again, it may be a common manifestation, the pair joyfully exulting in a nuptial rolling from side to side.

Those who are not coupled plunge their rostrum into the budding flowers and feast 


\section{The Life of the Weevil}

deliciously. Others bore little brown holes in the tiny twigs, whence oozes a drop of syrup which the Ants will come and lick up presently. And that, for the moment, is all. There is nothing to tell us where the eggs will be laid.

In July, certain capsules, still quite small, green and tender, have at their base a brown speck which might well be the work of the Cionus placing her eggs. I have my doubts: most of these punctured capsules contain nothing. The grubs then left their cell shortly after the hatching, the aperture, still open, allowing them to pass.

This emancipation of the new-born grubs, this premature exposure to the dangers of the outside world, is not consistent with the habits of the Weevils, who are great stay-athomes while in the larval state. Legless, plump, fond of repose, the grub shrinks from change of place; it grows up on the spot where it was born.

Another circumstance increases my perplexity. Among the capsules which the Weevil seems to have perforated with her rostrum, some contain eggs of an orange yellow, grouped into a single heap of five or six or 


\section{The Cionus}

more. This multiplicity gives us food for reflection. When fully matured, the capsules of the scollop-leaved mullein are small, greatly inferior in size to those of other plants of the same genus. When still very young, green and tender, those containing the eggs are hardly as big as half a grain of wheat. There is not food for so many feasters in so tiny a morsel; there would not be enough for one.

All mothers are provident. The exploiter of the mullein cannot have endowed her six or more nurselings with such scanty possessions. For these various reasons, I doubt at first whether these are really the Cionus' eggs. What follows is not calculated to decrease my hesitation. The orange eggs hatch out, producing grubs which within twenty-four hours abandon their exiguous natal chamber. They emerge through the orifice which has been left open; they spread over the capsule, cropping its down, a pasture sufficient for their first mouthfuls. They descend to the thin little twigs, which they strip of their bark, and gradually move on to the small ajacent leaves, where the banquet is continued. Let us leave them to grov: 


\section{The Life of the Weevil}

Their final transformation will tell me that I really have the authentic larva of the Cionus before my eyes.

They are bare, legless grubs, of a uniform pale yellow, excepting the head, which is black, and the first segment of the thorax, which is adorned with two large black spots. They are varnished all over their bodies with a glutinous humour, so much so that they stick to the paint-brush used to collect them and are difficult to shake off. When teased, they omit from the end of their intestine a viscous fluid, apparently the origin of their valnish.

They wander idly over the young twigs, whose bark they gnaw down to the wood; they also browse on the leaves growing from the twigs, which are much smaller than those upon the ground. Having found a good grazing-place, they stay there without moving, curved into a bow and held in position by their glue. Their walk is an undulating crawl, based upon the support of their sticky behind. Helpless cripples, but coated with an adhesive varnish, they are firmly enough fixed to resist a shake of the bough that bears them without falling 


\section{The Cionus}

off. When you have no sort of grapnel to hold on by, the idea of clothing yourself in glue, so that you may shift your position without danger of falling, even in a gust of wind, is an original invention of which, as yet, I know no other instance.

Our grubs are easily reared. Placed in a glass jar, with a few tender twigs of the plant that feeds them, they go on browsing for some time and then make themselves a pretty empulla in which the transformation will take place. To observe this performance and discover the method employed was the chief purpose of my enquiry. I succeeded, though not without a great expenditure of assiduity.

All its life long, the larva is smeared, on both its dorsal and its ventral surface, with a viscous, colourless, strongly adhesive fluid. Touch the creature lightly, anywhere, with the tip of a camel-hair pencil. The glutinous matter yields and draws out into a thread of a certain length. Repeat the touch in the hot sunshine, in very dry weather. The viscosity is not diminished. Our varnishes dry up; the grub's does not; and this is a property of the greatest value, enabling the feeble 


\section{The Life of the Weevil}

larva, without fear of being shrivelled by the wind or the rays of the sun, to adhere firmly to its food-plant, which loves the open air and warm, sunny places.

The laboratory producing this sticky varnish is easily discovered; we have only to make the creature move along a slip of glass. We see from time to time a sort of treacly dew oozing from the end of the intestine and lubricating the last segment. The glue is therefore supplied by the digestive canal. Is there a special glandular laboratory there, or is it the intestine itself that prepares the product? I will leave the question unanswered, for nowadays I no longer have the steady hand or the keen sight required for delicate dissection. The fact remains that the grub daubs itself with a glue of which the end of the intestine is at least the storehouse, if it is not the actual source.

How is the sticky emission distributed over the whole body, both above and below? The larva is a legless cripple; it moves about by obtaining a hold with its behind. Moreover, it is well segmented. The back, in particular, has a series of fairly protuberant cushions; the ventral surface, on the other 


\section{The Cionus}

hand, is puckered by knotty excrescences, which change their shape considerably in the act of crawling. When moving, with the flexible fore-part of the body groping to find its way, the grub consists of a series of waves that follow one another in perfect order.

Each wave starts from the hinder extrem. ity and by swift degrees reaches the head. Straightway a second wave follows in the same direction, succeeded by a third, a fourth and so on, indefinitely. Each of these waves, proceeding from one end of the grub to the other, is a step. So long as the wave continues, the fulcrum, that is, the orifice of the intestine, remains in its place, at first a little before and then a litle behind the movement as a whole. Hence the source of the sticky dew grazes first the tip of the abdomen and then the end of the back of the moving grub. In this way the tiny drop of gum is deposited above and below.

The glue has still to be distributed. This is done by crawling. Between the puckers, the cushions, which the locomotory wave brings together and then separates, alternately come into contact and open clefts into which the sticky fluid gradually makes its way 


\section{The Life of the Weevil}

by capillary action. The grub clothes itself in glue without exercising any special skill, merely by moving along. Each locomotory wave, each step, supplies its quota to the viscous doublet. This makes up for the losses which the larva cannot fail to suffer on the road as it roams from pasture to pasture; and, since the fresh material balances the wastage of the old, a suitable coat is obtained, neither too thin nor too thick.

The complete coating is rapidly effected. With the tip of a camel-hair pencil, I wash a grub in a little water. The viscosity dissolves and disappears; and the water used for washing the larva, evaporated on a slip of glass, leaves a mark like that of a weak solution of gum arabic. I place the grub to dry on blotting-paper. When I now touch it with a straw, it no longer sticks to it; it has lost its coating of varnish.

How will it replace it? This is a very simple matter. I allow the grub to move about at will for a few minutes. No more is needed; the layer of gum is restored; the creature sticks to the straw that touches it. To sum up, the varnish with which the 


\section{The Cionus}

Cionus' larva is covered, is a viscous fluid, soluble in water, quickly emitted and extremely slow to dry, even in an intensely hot sun and in the parching breath of the Northwind.

Having obtained these data, let us see how the ampulla is constructed in which the transformation will take place. On the $S$ th of July i 906, my son Paul, my zealous collaborator now that my once sturdy legs are failing me, brings me, on returning from his morning walk, a magnificent branching head of mullein peopled by the Cionus. It contains an abundance of larva. Two of them in particular delight me: while the others stand browsing, these two wander about restlessly, indifferent to their food. Beyond any doubt, they are looking for a spot favourable to the process of the nymphosis.

I place each of them singly in a small glass tube which will allow me to observe them easily. In case they might find the food-plant useful, I supply them with a sprig of mullein. And now, lens in hand, from morning to evening and then by night, as far as drowsiness and the doubtful light of a can- 


\section{The Life of the Weevil}

dle will permit, let us be on the alert; for very interesting things are about to happen. Let me describe them hour by hour.

8. A. M.-The larva is not making use of the twig with which I provided it. It is crawling along the glass, darting its pointed head now this way, now that. With a gentle creeping movement that causes an undulation of the back and belly, it is trying to settle itself comfortably. After two hours of this effort, which is certain to be accompanied by an emission of viscous fluid, it finds a position to its taste.

IO A. M.-Being now fixed to the glass, the larva has shrunk into the semblance of a little barrel, or a grain of wheat with rounded ends. At one end is a shining black speck. This is the head, jammed into a fold of the first segment. The grub's colour is unchanged: it is still a dirty yellow.

I P. M.-A copious emission of fine black granules, followed by semifluid dejecta. To avoid soiling its future residence and to prepare the intestine for the delicate chemistry about to follow, the grub purges itself beforehand of its impurities. It is now a uniform pale yellow, without the cloudy markings 


\section{The Cionus}

that disfigured it at first. It is lying at full length on its ventral surface.

3 P. M.-Under the skin, especially on the back, the lens reveals subtle pulsations, slight tremors, like those of a liquid surface on the point of boiling. The dorsal vessel itself is dilating and contracting, throughout its length, more actively than usual. This means a fit of fever. Some internal change must be preparing, which will affect the whole organism. Can it be the preparation for a moult?

5 P.M.-No, for the grub is no longer motionless. It leaves its heap of dirt and begins to move along impetuously, more restlessly than ever. What is happening that is in any way unusual? I think I can obtain some idea of it with the aid of logic.

Remember that the sticky coat in which the grub is clad does not dry up: this is a condition indispensable to liberty of movement. If changed into a hard varnish, a dry film, it would hamper, would indeed stop the crawling; but, so long as it remains liquid, it is the drop of oil that lubricates the locomotory machine. This moist coating will however, constitute the material of the nym- 


\section{The Life of the Weevil}

phosis-bladder: the fluid will become goldbeater's-skin, the liquid will solidify.

This change of condition at first suggests oxidation. We must abandon this idea. If the hardening were really the result of oxidization, the grub, being sticky from its birth and always exposed to the air, would long ago have been clad not in a delicate coat of adhesive, but in a stiff parchment sheath. Desiccation obviously must take place at the last moment and rapidly, when the grub is preparing to change its shape. Before then, this desiccation would be a danger; now, it is an excellent means of defence.

To "fix" oil-paintings our ingenuity employs siccatives, that is to say, ingredients that act upon the oil, giving it a resinous consistency. The Cionus likewise has its siccative, as the following facts prove. It may be that the grub was labouring to produce this desiccating substance, by some profound change in the process of its organic laboratory, at the time when its poor flesh was quivering with feverish tremors; it may be that it was proceeding to spread the sic- 


\section{The Cionus}

cative over the whole surface of its body by taking a long walk, the last of its larval life.

7 P. M.-The larva is once more motionless, lying flat on its belly. Is this the end of its preparations? Not yet. The globular structure must have a foundation, a base on which the grub can support itself in order to dilate its ampulla.

8 P. M.-Round the head and the forepart of the thorax, which, like the rest of the body, are touching the slip of glass, a border of pure white now appears, as though snow had fallen at these points. This forms a sort of horse-shoe enclosing an area in which the snowy deposit is continued in a vague mist. From the base of this border some threads of the same white substance radiate in short tufts. This structure denotes work done with the mouth, a miniature wire-drawing. And in fact no such white substance is seen anywhere except around the head. Thus the creature's two ends take part in the building of the hut: the one in front provides the foundations, the one behind provides the edifice.

Io P. M.-The larva shrinks. With its 323 


\section{The Life of the Weevil}

support, that is to say, its head anchored to the snowy cushion, it brings its hinder end a little nearer; it coils up, hunches its back and gradually turns itself into a ball. Though not yet perceptible, the ampulla is being prepared. The siccative has taken effect; the original gumminess has been transformed into a sort of skin, flexible enough at this moment to be distended by the pressure of the back. When its capacity is large enough, the grub will become unglued, throw off its envelope and find itself at liberty in a spacious enclosure.

I should much like to see this peeling, but things happen so slowly as to drive one to despair. Let us go to bed. What I have seen is enough to enable me to guess the little that remains to be seen.

Next day, when the pale dawn gives me sufficient light, I hasten to my two larva. The bladder is completed. It is a graceful ovoid of the finest gold-beater's-skin, adhering at no point to the insect inside. It has taken some twenty hours to manufacture. It has still to be strengthened with a lining. The transparency of the wall enables us to follow the operation. 


\section{The Cionus}

We see the grub's little black head rising and falling, swerving this way and that and from time to time gathering with its mandibles, at the door of the intestine, a particle of cement, which is instantly placed in position and meticulously smoothed. So the interior of the hut is plastered, point after point, by small touches. Lest I should not see clearly through the wall, I cut off the top of a bladder, partly uncovering the larva. The work is continued without much hesitation. The strange method is revealed as plainly as one could wish. The grub makes use of its behind as a store of consolidating cement; the end of the intestine serves as the equivalent of the hod from which the bricklayer takes his trowelful of mortar.

This original mode of procedure is familiar to me. At one time, a big Weevil, the Spotted Larinus, inhabiting the blue-headed globe-thistle (Echinops Ritro), enabled me to witness a similar method. The Larinus also expels its own cement. With the tips of its mandibles it gathers it from the evacuating orifice, applying it with strict economy. Moreover it has other materials at its dis- 


\section{The Life of the Weevil}

posal, the hairs and remnants of the florets of its thistle. Its cement is used only to plaster and glaze the work. The Cionus' larva, on the other hand, employs nothing but the oozings of its intestine; consequently the little hut resulting is of incomparable perfection.

Besides the Spotted Larinus, my notes mention ather Weevils, for instance, the Garlic-Weevil (Brachycerus algirus), whose larvæ possess the art of coating their cells with a thin glaze provided by the rump. This intestinal artifice seems, therefore, to be pretty frequently employed by the Weevils that build little chambers in which the metamorphosis is to take place; but none of them excel in it as does the Cionus. Its task becomes yet more interesting when we consider that, in the same factory, after a very brief interval, three different products are compounded: first a liquid glue, a means of adhesion to the swaying support of the mullein lashed by the winds; then a siccative fluid which transforms the sticky coating into gold-beater's-skin; and lastly a cement which strengthens the bladder separated from the larva by a sort of moult. What a 


\section{The Cionus}

laboratory, what exquisite chemistry in a scrap of intestine!

What use are these minute details, noted hour by hour? Why these puerilities? What matters to us the industry of a wretched grub, hardly known even to the professional experts?

Well, these puerilities involve the most weighty problems that we are privileged to discuss. Is the world an harmonious creation, governed by a primordial force, a causa causarum? $\mathrm{Or}$ is it a chaos of blind con. flicting forces, whose reciprocal thrusts produce a chance equilibrium, for better or for worse? Minute entomological details examined with some thoroughness, may serve us better than syllogisms, in the scientific in. vestigation of these trifles and others like them. The humble Cionus, for its part, tells us of a primordial force, the motive power of the smallest as of the greatest things.

A day is not too long to give the bladder a good lining. Next day, the larva molts and passes into the nymphal state. Let us complete its story with the data gleaned in the fields. The cocoons are often found on the grass near the food-plant, on the stalks 


\section{The Life of the Weevil}

and dead blades of the Graminea. Generally, however, they occupy the little twigs of the mullein, stripped of their bark and withered. The adult insect emerges sooner or later in September. The gold-beater'sskin capsule is not torn irregularly, at random; it is neatly divided into two equal parts, like the two halves of a soap-box.

Has the enclosed insect gnawed the casing with its patient tooth and made a fissure along the equator? No, for the edges of either hemisphere are perfectly clean-cut. There must, therefore, have been a circular line ready to facilitate the opening. All that the insect had to do was to hunch its back and give a slight push, in order to unfasten the roof of its cabin all in one piece and set itself free.

I can just see this line of easy rupture on certain intact capsules. It is a faint line ringing the equator. What does the insect do beforehand to contrive that its cell shall open in this way? A humble plant, flowering early in the spring, the blue or scarlet pimpernel, has also its soap-box, its pyxidium, which splits easily into two hemispheres when the time comes for the seed to be scat- 


\section{The Cionus}

tered. In either case it is the work of an unconscious ingenuity. The grub does not plan its methods any more than the pimpernel: it has hit upon its ingenious scheme of joining the halves of its capsule by the inspiration of instinct alone.

More numerous than the capsules which burst accurately are others which are clumsily torn by a shapeless breach. Through this some parasite must have emerged, some ruthless creature which, unacquainted with the secret of the delicate joint, has released itself by tearing the gold-beater's-skin. I find its larva in cells which are not yet perforated. It is a small, white grub, fixed to a discoloured tit-bit which is all that remains of the Cionus' nymph. 'The intruder is sucking dry the rightful occupant, whose budding flesh is still quite tender. I think I can identify the murderess as a bandit of the Chalcid tribe, which is addicted to such massacres.

Her appearance and her gluttonous ways have not misled me. My rearing-jars provide me with abundant supplies of a small bronze-coloured Chalcid with a large head and a round, tapering body, but with no visible boring-tool. To enquire her name of the 


\section{The Life of the Weevil}

experts will not help me much. I do not ask the insect, "what are you called?" but "what are you able to do?"

The anonymous parasite hatched in my jars has no implement similar to that of the Leucospis, ${ }^{1}$ the chief of the Chalcididx; it has no probe which is able to penetrate a wall and place the egg, at some distance, on the food-ration. Her germ, therefore, was laid in the very flanks of the Cionus' larva, before the latter had built its shell.

The methods of these tiny brigands appointed to the task of thinning out the too numerous are extremely varied. Each guild has its own method, which is always horribly effective. How should so small a creature as the Cionus cumber the earth? No matter: it has to be massacred, to perish in its cradle, a victim of the Chalcid. Like other creatures, the peaceful dwarf must furnish its share of organizable matter, which will be further and further refined as it passes from stomach to stomach.

Let us recapitulate the habits of the Cionus, very strange habits in an insect of

${ }^{1}$ The Life of the Fly: chaps. ii. and iii.-Translator's Note. 


\section{The Cionus}

the Weevil series. The mother entrusts her eggs to the swelling capsules of the scollopleaved mullein. So far, everything is according to rule. Other Weevils, as a matter of fact, prefer, when setting their children up in life, the pods of some other mullein, or those of the figwort or of the snapdragon, two plants belonging to one and the same botanical family. But now we are suddenly confronted with the strange and exceptional. The mother Cionus choses the mullein with the smallest capsules, whereas in the neighbourhood and at the same season there are others loaded with fruit whose dimensions would provide spacious lodgings and abundance of food. She prefers dearth to plenty and narrow to spacious quarters.

Worse still. Indifferent to leaving provision for her brood, she nibbles the tender seeds, destroys them, extirpates them, in order to obtain a cavity in the heart of the tiny globule. Into this she slips more or less half a dozen eggs. With the edible substance left, were the whole cell to be consumed, there would not be enough to feed a single grub.

When the bread-pan is empty, the house is 


\section{The Life of the Weevil}

deserted. The young abandon their faminestricken dwelling on the day when they are hatched. They are bold innovators and practice a method which is held in detestation among the Weevils, who are all preeminently stay-at-homes: they dare the dangers of the outer world: they travel, passing from one leaf to another in search of food. This strange exodus, unprecedented in a Weevil, is not a mere caprice but a necessity imposed on them by hunger; they migrate because their mother has not provided them with anything to eat.

If traveling has its pleasures, enough to make the insect forget the delights of the cell in which it digests at peace, it also has its drawbacks. The legless grub can progress only by a sort of creeping gait. It has no instrument of adherence which will enable it to remain fixed to the twig, whence the least breath of wind may make it fall. Necessity is the mother of invention. To guard against the danger of falling, the wanderer smears itself with a viscous fluid, which varnishes it and makes it adhere to the trail which it is following.

But this is not all. When the ticklish 


\section{The Cionus}

moment of the nymphosis arrives, a retreat in which the grub can undergo its transformation in peace becomes indispensible. The vagabond has nothing of the sort. It is homeless, it sleeps in the open air; yet it is able, when the time comes, to make itself a tent, a capsule, the materials for which are supplied by its intestine. No other insect of its order can build a home like this. Let us hope that the hateful Chalcid, the murderer of nymphs, will not visit it in its pretty little tent.

The grub that lives on the scollop-leaved mullein has shown an utter revolution in the habits of the Weevil clan. The better to judge of this, let us consult a cognate species, placed not far from the Cionus by the classifiers; let us compare the two kinds of life, on the one hand the exception and on the other the rule. The comparison will be all the more useful inasmuch as the new witness also exploits a mullein. It is known as Gymnetron thapsicola, GERM.

Dressed in russet homespun, with a plump round body and about the size of the Cionus: there you have the creature. Note the qualifying thapsicola, meaning an inhabitant 


\section{The Life of the Weevil}

of the thapsus. On this occasion, I am glad to see, the term could not possibly be happier: it enables the novice to identify the insect exactly, without other data than the name of the plant on which it lives.

The botanist gives the name of Verbascum thapsus to the common mullein, or shepherd's club, a lover of the tilled fields in both the north and the south. Its bloom, instead of branching out like that of the scollop-leaved mullein, consists of one thick cone of yellow flowers. These flowers are followed by close-packed capsules about as big as a fairsized olive. Here we no longer have the niggardly pods in which the grub of the Cionus would die of starvation if it did not abandon them as soon as it is hatched; these caskets contain plenty of victuals for one larva and even for two. A partition divides them into two equal compartments, both of them crammed with seeds.

The fancy took me to estimate roughly the mullein's wealth of seeds. I have counted as many as $32 \mathrm{I}$ in a single shell. Now a spike of ordinary size contains I 50 capsules. The total number of seeds is therefore 48,000 . What can the plant want with 


\section{The Cionus}

such abundance? Allowing for the small number of seeds required to maintain the species in a thriving state, it is evident that the mullein is a hoarder of nutritive atoms; it creates foodstuffs; it summons guests to its opulent banquet.

Knowing these facts, the Gymnetron, from May onwards, visits the luxuriant flowerspike and there installs her grubs. The inhabited capsules may be recognized by the brown speck at their base. This is the hole bored by the mother's rostrum, the aperture needed for inserting the eggs. Usually there are two, corresponding with the two cells of the fruit. Soon the oozings from the cell set hard and dry and obstruct the tiny window; and the capsule is closed again, without any communication with the outer world.

In June and July, let us open the shells marked with brown specks. Nearly always we find two grubs, looking fat as butter, with their fore-parts swollen and their hinder parts shrunken and curved like a comma. Not a vestige of legs, which members would be very useless in such a lodging. Lying at its ease, the grub has plenty of food ready to its mouth: first the tender, sugary seeds; 


\section{The Life of the Weevil}

then the placenta, their common support, which is likewise fleshy and highly flavoured. It is pleasant to live under such conditions, motionless and devoting one's self entirely to the joys of the stomach.

It would take a cataclysm to upset the smug hermit. This cataclysm I bring about by opening the cell. Then and there, the grub begins to twist and wriggle desperately, hating any exposure to the air and light. It takes more than an hour to recover from its excitement. Here assuredly is a grub that will never be tempted to leave its home and go wandering about like the Cionus' larva. It is most highly domestic by inheritance and domestic it will remain.

It refuses even to go next door. In the same capsule, on the other side of the partition, a neighbour is nibbling away. Never does it pay the neighbour a visit, though it could easily do so by perforating the partition, which at this moment is an actual sort of cake, no less tender than the seeds and the placenta. Each holds the other's share of the capsule inviolable. On the one hand is one grub; on the other hand is another; and never do the two hold the least communi- 
cation through the little skylight. A grub's home is its castle.

The Gymnetron is so happy in her cell that she stays there a long time after assuming her adult form. For ten months out of the twelve she does not leave it. In April, when the buds of the new twigs are swelling, she pierces the natal capsule, now a mighty donjon; she comes out and revels in the sun on the recent flower-spikes, which grow daily longer and thicker; she frisks in couples and, in May, establishes her family, which will obstinately repeat the sedentary habits of the elders.

With these data before us, let us philosophize awhile. Every Weevil spends its larval life on the spot where the egg was laid. Various larvæ, it is true, when the time of metamorphosis approaches, migrate and make their way underground. The Brachycerus abandons its clove of garlic, the Balaninus its nut or acorn, the Rhynchites its vine-leaf or poplar-leaf cigar; the Ceuthorhynchus its cabbage stalk. But these instances of desertion on the part of grubs which have attained their full growth do not in any way invalidate the rule: all Weevil- 


\section{The Life of the Weevil}

larvæ grow up in the actual place where they are born.

Now here, by a most unexpected change of tactics, the Cionus-grub, while still quite young, quits its natal cell, the capsule of the mullein; it longs for the outer world, that it may browse in the open air on the bark of a twig; and this entails upon it two inventions elsewhere unknown: the sticky coat, which gives it a firm hold when it moves from place to place, and the gold-beater's-skin ampulla, which serves to house the nymph.

What is the cause of this aberration? Two theories are suggested, one based on decadence, the other on progress. Of old, we tell ourselves, the mother Cionus, far back in the ages, used to obey the conventions of her tribe. Like the other Weevils that munch unripe seeds, she favoured large capsules, enough to feed a sedentary family. Later, by inadvertence or flightiness or for some other reason, she turned her attention to the stingy scollop-leaved mullein. Faithful to ancient custom, she rightly chose for her domain a plant of the same family as that which she first exploited; but it unfortunately happens that the mullein adopted is 


\section{The Cionus}

incapable of feeding a single grub in its fruit, which is too small for the purpose. The mother's ineptitude has led to decadence; the perils of a wandering life have taken the place of a peaceful, sedentary existence. The species is on the high road to extinction.

Again, we might argue as follows, at the outset, the Cionus had the scollop-leaved mullein as her portion; but, since the grubs do not thrive when thus installed, the mother is searching for a better means of setting them up in life. Gradual experiment will one day show her the way. From time to time, indeed, I find her on Vervascum maiale or Verbascum thapsus, both of which have large capsules; only she is there by accident, in the course of a trip, thinking of obtaining a good drink and not of laying her eggs. Sooner or later, the future will establish her there for the sake of her family. The species is in process of improvement.

By dressing up the matter in uncouth phrases, calculated to conceal the vagueness of the thought behind them, we might represent the Cionus as a magnificent example of the changes which the centuries bring about in the habits of insects. This would sound 


\section{The Life of the Weevil}

extremely learned, but would it be very intelligible? I doubt it. When my eyes fall upon a page bristling with barbarous and socalled scientific locution, I say to myself: "Take care! The author has not quite grasped what he is saying, or he would have found, in the vocabulary hammered out by so many brilliant minds, words that would express his thought more plainly."

Boileau, ${ }^{1}$ who has been denied poetic inspiration, but who certainly possessed common-sense and plenty of it, tells us:

"Ce que l'on concoit bien s'énonce clairement." 2

Just so, Nicolas! Yes, clearness, clearness always! He calls a spade a spade. Let us do as he does, let us qualify as gibberish any over-learned prose that reminds us of Voltaire's witty sally:

"When the listener does not understand and the speaker does not himself know what he is saying, then they are talking metaphysics."

"And advanced science," let us add.

1 Nicholas Boileau-Despréaux (1636-17II), author of L'Art poétique and other poetical, critical and satirical works.-Translator's Note.

2 "That which is well conceived is also clearly stated." 


\section{The Cionus}

We will confine ourselves to stating the problem of the Cionus, without much hope that some day it will be clearly solved. For that matter, if the truth be told, it may be that there is no problem at all. The grub of the Cionus was a vagabond in the beginning and a vagabond it will remain, among the other Weevil-grubs, which are all essentially stay-at-home larvæ. Let us leave it at that: it is the simplest and most lucid explanation. 



\section{Index}

A

Acorn-weevil (see Elephant Weevil)

Agrippa, 5, 8

Antony (see Mark Antony)

Anthidium, 200

Apoderus coryli (see Apoderus of the Hazel)

Apoderus of the $\mathrm{Hazel}_{3}$ 175, I77, I $81,183,186$, 196

Aristophanes, 272

Artichoke-weevil, 61, 69, 85

Attelabus curculionoides,

I75, 185, 187, I91, 195, 196

Augustus, 5, 6

\section{B}

Balaninus (see the varieties below)

Balaninus elephas (see Elephant Weevil)

Balaninus nucum (see Nutweevil)

Bear (see also Cavebear), 5

Bear Lairnus, 54, 58, 60, 83

Bécaru (see Vine-weevil)

Black, Adam and Charles, $\mathrm{V}$

Blackbird, 107, 108, I 10

Bluebottle, 250

Boileau-Despréaux Nicolas, 340
Bombyx, 163

Brachycerus algirus, 169 , I 71, 218, 326, 337

Bruchus (see Haricotweevil. Pea-weevil)

Burying-beetle (see Necrophorus)

Butterfly (see also the varieties), 76,77

C

Caggae Butterfly (see Large White Butterfly)

Capricorn, $17,18,44,72$, $73,133,155,156,288$

Carabus, 17, 18, 307

Carcharodon megalodon, 9

Cave-bear, 230

Cerambyx heros (see Capricorn)

Cerceris, 78, $\mathbf{I} 44$

Cetonia (see C. Aoricola, Rose-chafer)

Cetonia floricola, 45, 72, $77,219,307$

Ceutorhyncus, 337

Chalcid, 264, 329, 330, 333

Chalcis, 262, 263

Chalicodoma (see Masonbee)

Cicada, 30, 293

Cionus, (see Cionus Thapsus)

Cionus Thapsus, 308, 309, 3I0, 3I2, 3I3, 3I4, 3I9, $322,326,330,338,339$, 34 I 


\section{Index}

Clam (see Surf Clam)

Cleopatra, 7

Cockchafer (see Pine Cockchafer)

Columella, 229

Conus, II

Copris, 74, 225, (see also Spanish Copris)

Corn-iveevil, 232, 284

Cotton-bee (see Anthidium)

Courcoussoun (see Haricotweevil)

Cricket, 173

Crocodile, 6, 12, 22

Cuckoo, II 3

Cytherida, II

\section{D}

Dove, 19

Dung-beetle, I7, 73, 78, 200, 224, (see also Bolbites, Copris, Necrophorus, Onitis, Onthophagus, Phanaeus, Sacred Beetle)

Dytiscus, 18

E

Edible Snail (see Large Edible Snail)

Elephant Weevil, 88, I2I, 122

\section{F}

Falcon, 5

Field-mouse, 108, 109, 132, 133, 136

Fly, 16, 142

\section{G}

Garlic-weevil (see Brachycerus Algirus)

Gnat, I 5, I6

Grasshopper, 30, II3, II 6

Great Water-beetle, 18

Green Lizard, 19

Ground-beetle (see Carabus)

Gymnetron thapsicola, 136, I 37, 333, 335, 337

Gyrinus (see Whirligig Beetle)

$\mathrm{H}$

Haricot-weevil, 236, 279, $280,283,285,286$

Hedgehog, 26

Helix pomatia (see Large Edible Snail)

Heredia, José Maria de, 275

Hunting Wasp, (see Cerceris, Sphex)

Hydrophilus (see Great Water-beetle)

I

Ichneumon-fly, 30, I1 6

Iris-weevil, 294, 295, 298

L

La Fontaine, Jean de, II 7

Lamia denticulata, 9

Large Edible Snail, 18c

Large White Butterfly, 76, 77

Larinus (see also the varieties below), 23, 24 and Seq. 


\section{Index}

Larinus conspersus (sec

$\mathrm{O}$

Spangled Larinus)

Larinus maculosus (see Spotted Larinus)

Larinus scolymi (see Artichoke-weevil)

Larinus stolatus (see Stoled Larinus)

Larinus ursus (see Bear Larinus)

Leucospis, 30, II4, 330

Lithodomus, ro

Lizard (see Green Lizard)

Louse (see Phylloxera)

\section{M}

Macmillan Co. V

Mactra, II

Mark Antony, 7

Mason-bee, II 4

Mastodon, I 5

Miall, Bernard, V

Midge, 15

Minotaur (see Minotaurus. Typhoeus)

Minotaurus Typhoeus, 307

Mitre-shell (see Turritella)

Mononychus pseudo-acori (see Iris-weevil)

Mosquito (see also Gnat), 15

\section{$\mathrm{N}$}

Necrophorus, 74, 250

Notidanus primigenius, 9

Nut-weevil, 117, I19, I21, I 22, I 98, 22 I

(ctavius (sce Augustus)

Unitis, 45

Unthophagus, 45

Ovid, 27 I

Ox, 252

Oxyrhina xyphodon, 9

Oyster, II

Pea-weevil, 233, 236, 238:

242, 248, 251, 253, 254, $255,259,262,280,283$, $285,289,298,299$

Petricola, ro

Phanaeus (see Phanaeus Milon, Splendid Phanaeus)

Phanaeus Milon, 200, 225, 226

Pholas (see Piddock)

Phylloxera, 285

Piddock, ro

Pieris (see Large White Butterfy)

Pig, 6, 110

Pine Cockchafer, 72, 73, 76,77

Plautus, 272

Pliny the Elder, 2

Pliny the Younger, 2

Poplar-weevil, I39, I60, 172, 194, 196, 206, 207

Porker (see Pig)

Puma, 5

$\mathrm{R}$

Raspail, François Vincent, 170 


\section{Index}

Rat, 117

Resin-bee (see Anthidium)

Rhynchites (see the varieties below)

Rhynchites auratus (see Sloe-weevil)

Rhynchites Bacchus, 199

Rhynchites betuleti (see Vine-weevil)

Rhynchites populi (see Poplar-weevil)

Rhynchophora, 16, 236

Robin Redbreast, 19

Rose-chafer, 45, 73

Rotifer, 195

$\mathrm{S}$

Saw-fly, 30

Scallop, I I

Sea-urchin, 7, 10, 26

Shark, 9

Sheep, 6, 232, 310

Silk-worm Moth (see

Bombyx)

Sloe-weevil, 196, 197, 206, 228

Snail (see also Large

Edible Snail), I79

Spangled Larinus, 66, 85

Spanish Copris, 224, 225

Sphex, 74, 250
Spotted Larinus, 26, 35, 39, $49,57,59,325$

Stoled Larinus, 55

T

Teixeira de Mattos, Alexander, $\mathrm{V}$

Tortoise, 12

Tree-frog, 294

$\mathrm{U}$

Unwin, T. Fisher, Ltd., V

Ursus spelaeus (see Cavebear)

V

Vanessa, 76, 77

Varro, 229

Vine-weevil, 158, I 59, I60, I 74, 194, 196, 206

Virgil, 5, 273

Vitruvius, 45

Voltaire, 345

IV

Water-beetle (see Great W ater-beetle)

Wheel Animalculae (see Rotifer)

Whirligig Beetle, 18

White Butterfly (see Large White Butterfly) 





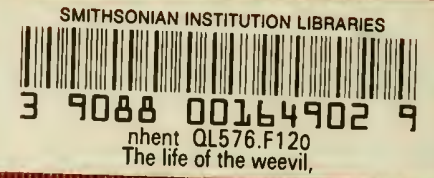

